\title{
4 norden
}

\section{Together Alone}

BASIC countries and the climate change conundrum

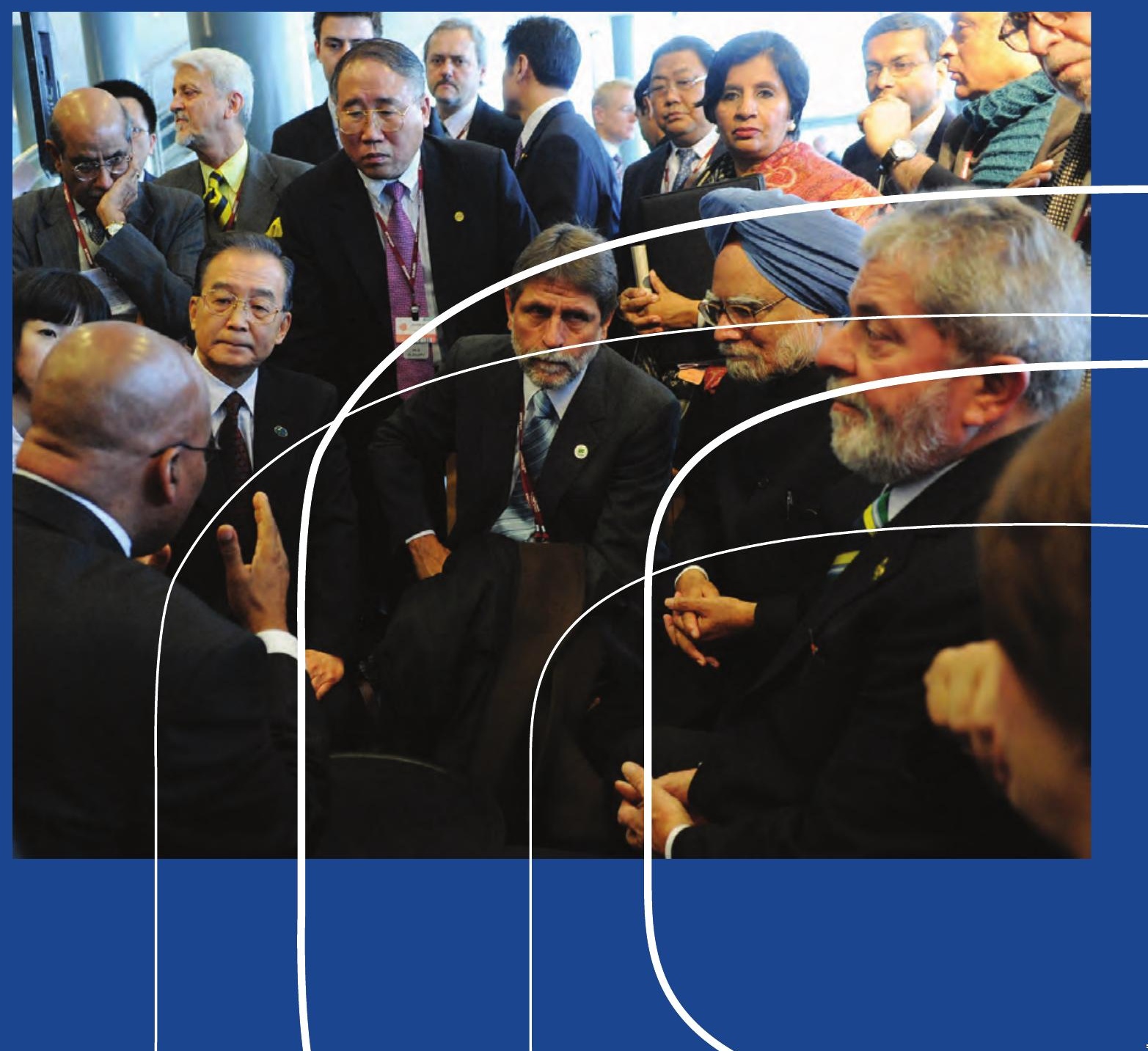






\section{Together Alone}

BASIC countries and the climate change conundrum

Karl Hallding, Marie Olsson, Aaron Atteridge, Antto Vihma, Marcus Carson and Mikael Román 


\section{Together Alone}

BASIC countries and the climate change conundrum

TemaNord 2011:530

ISBN 978-92-893-2224-9

(C) Nordic Council of Ministers, Copenhagen 2011

Print: Rosendahls Bogtrykkeri AS

Copies: 800

Cover photo: IISD/Earth Negotiations Bulletin

Printed in Denmark

This publication has been published with financial support by the Nordic Council of Ministers. But the contents of this publication do not necessarily reflect the views, policies or recommendations of the Nordic Council of Ministers.

www.norden.org/publications

\section{Nordic co-operation}

Nordic cooperation is one of the world's most extensive forms of regional collaboration, involving Denmark, Finland, Iceland, Norway, Sweden, and Faroe Islands, Greenland, and Åland.

Nordic cooperation has firm traditions in politics, the economy, and culture. It plays an important role in European and international collaboration, and aims at creating a strong Nordic community in a strong Europe.

Nordic cooperation seeks to safeguard Nordic and regional interests and principles in the global community. Common Nordic values help the region solidify its position as one of the world's most innovative and competitive.

\section{Nordic Council of Ministers}

Ved Stranden 18

DK-1061 Copenhagen K

Phone (+45) 33960200

www.norden.org 


\section{Content}

Nordic Council of Ministers' Preface ………....................................................................

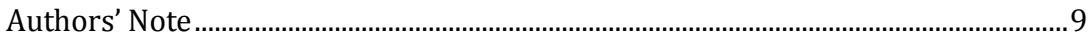

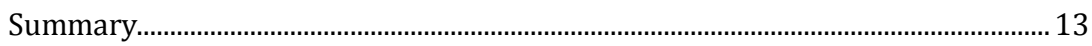

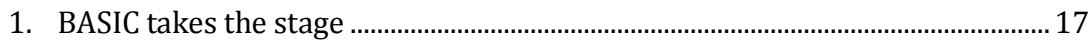

2. The origins of BASIC: Developing country roots and the image of

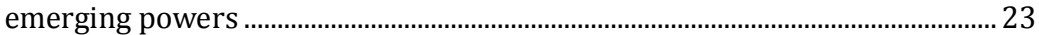

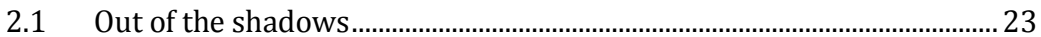

$2.2 \quad$ Normative roots in the G77 ........................................................................... 25

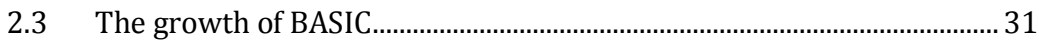

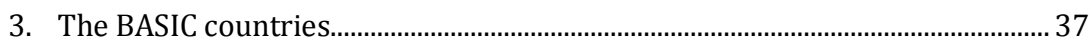

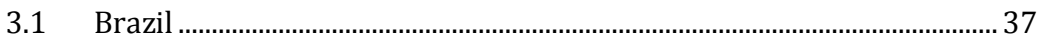

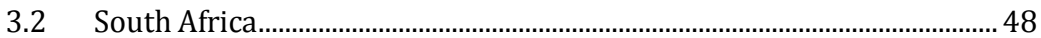

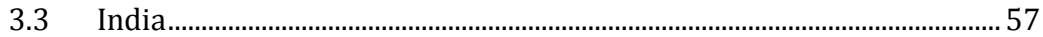

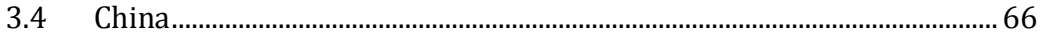

4. BASIC's emergence and wider geopolitical change ............................................. 77

4.1 Reasons for emerging economies to cooperate ........................................ 78

4.2 Different constellations of emerging economies.......................................... 81

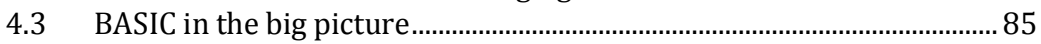

5. BASIC and a climate agreement: Disunity or shared vision?................................91

5.1 Cooperation and contention ....................................................................... 91

5.2 Does BASIC have a shared vision? ............................................................ 96

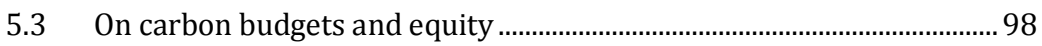

5.4 What does this imply for BASIC's future? .................................................101

6. Trends and developments: Where is BASIC heading? .......................................103

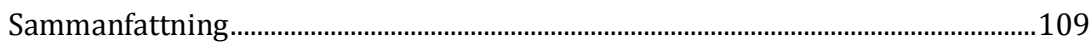

Appendix A: Methods and conceptual framework ..................................................113

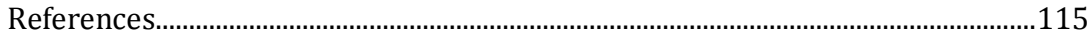





\section{Nordic Council of Ministers' Preface}

This report, co-financed by the Nordic Council of Ministers, is the result of a year-long research project driven by a quest for better understanding on how the emerging BASIC powers - Brazil, South Africa, India and China approach international climate negotiations as a group.

These fast growing economies will contribute to an increasing amount of $\mathrm{CO}_{2}$ emissions, while at the same time partly reducing their $\mathrm{CO}_{2}$ emissions. This reduction will take place under comparatively progressive national climate policies and concrete measurable mitigation actions.

Therefore these countries are important partners and crucial actors in a final UN climate negotiations solution and we hope this report can contribute to the work leading up to the climate negotiations at COP17 in Durban, December 2011.

The study has been carried out by the Stockholm Environment Institute with close cooperation and contribution from the Finnish Institute of International Affairs for the Nordic Working Group for Global Climate Negotiations (NOAK), a working group under the Nordic Council of Ministers.

The aim of NOAK is to contribute to a global and comprehensive agreement on climate change with ambitious emission reduction commitments. To this end, the group prepares reports and studies, conducts meetings and organizes conferences supporting the Nordic negotiators in the UN climate negotiations. 
The Nordic Council of Ministers is happy to be able to contribute to expanding the knowledge base of the global climate negotiations through this report and the ongoing work of NOAK.

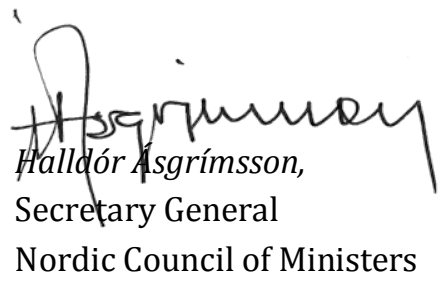




\section{Authors' Note}

"To see ourselves as others see us is a rare and valuable gift, without a doubt. But in international relations what is still rarer and far more useful is to see others as they see themselves."

Jacques Barzun

The motivation for this work comes first and foremost from a desire to see meaningful progress within the international climate change negotiations. Work towards a global climate agreement under the UNFCCC has been a long and difficult process, and it is clear that many of the remaining obstacles to a comprehensive agreement are the result of countries beginning from different 'starting positions' - in development terms, in energy resources, in economic strength, and in ideology. In essence, different countries quite naturally have differing perspectives on how a meaningful agreement might best be reached and what that agreement should look like.

Our study begins from an observation that these differences often have not been well understood by individual parties, and that this lack of understanding has often contributed to a lack of trust between parties. It is our hope, therefore, that by delving deeper into the BASIC countries and their efforts at cooperation we might facilitate a more sophisticated, nuanced understanding of these parties, and that this can help the international process find ways of overcoming differences and breaking deadlocks. While our focus is on BASIC, an attempt to more deeply understand what drives the climate agenda could and should also be applied to other parties.

Our study does not focus on the intricate details of the negotiation process under the UNFCCC. Instead we have set our analytical lens wider, to see the practice of climate diplomacy as being part of a broader picture in which political representatives from all countries are responding to and balancing many different concerns and interests - both domestically and internationally - in formulating a set of negotiation positions on climate change. Essentially, we approach the question of how and why the BASIC 
countries came together by examining how different domestic factors have influenced and conditioned the group's interactions. We have also looked beyond the climate negotiations to explore the broader geopolitical dimensions of the BASIC cooperation.

There is rather little peer-reviewed work on the cooperation and relations between the BASIC countries. While our research has been based on both academic and grey literature, we have gained considerable insights into how the BASIC cooperation has unfolded by extensive Internet based research, including analytical pieces such as briefing papers and reports from research institutions, opinion editorials and news reporting, as well as blog posts.

The most crucial source of data for this study has been interviews with almost 100 informants, including policy makers, negotiators, researchers, as well as representatives of informed civil society including the business community, representatives of non-governmental organisations and news media. The selection was made to ensure a broad representation of all the different actors involved in, or closely observing, the UN climate negotiations, ensuring a holistic picture of the BASIC group. The interviewees were chosen based on their own unique experience and perspective. Interviews were carried out during a number of visits to all four BASIC countries from January 2010 to June 2011 and observations at UN negotiation sessions in Tianjin in October 2010 and Bonn in June 2011.

In addition to one-on-one interviews, the authors have also conducted a number of informal group discussions in Europe. We are particularly grateful to Christer Hammarlund at the European Commission's Information Society and Media Directorate General (INFSO) for arranging an informal dialogue with officials from the Climate Directorate in January 2011, and to Bernice Lee and Felix Preston at Chatham House for arranging a similar informal discussion with leading experts from the London area in February 2011.

Three seminars were held to support the collaboration between the Stockholm Environment Institute (SEI) and the Nordic Ad Hoc Group on Global Climate Negotiations (NOAK). These seminars gathered negotiators, senior diplomats, desk officers and researchers from the Nordic countries and were generally centred on preliminary findings of research. SEI hosted the first seminar in Stockholm in August 2010, the Finnish Institute of International Affairs hosted the second in Helsinki in Novem- 
ber 2010, and the Norwegian Ministry of the Environment hosted the third in Oslo in February 2011.

We are also grateful to the Finnish NOAK chairmanship and the Finnish EU Delegation in Brussels for arranging an open seminar in Brussels in March 2011 with participation of high-level EU and European officials, where we received valuable feedback from Peter Wittoeck and Herman Sips on an early draft manuscript. Finally, SEI organised a well-attended side event at the UN climate negotiation session in Bonn in June 2011 where many of our findings were discussed and critiqued.

All interviewees for this study have been asked to respond in their own personal capacity. As the BASIC cooperation story contains sensitive matters, all responses have been treated anonymously, meaning that we have used the information gathered through interviews but have not quoted interviewees directly or cited them as sources. We trust readers will understand the necessity of this approach and hope you can accept our assurances that unattributed material has been carefully researched and cross-checked.

We would like to extend our warmest thanks to the following interviewees and commentators who generously gave of their time, insights, and experience:

Sushil Aaron, Sergio Abranches, Stefan Agne, Branca Americano, Monica Araya, Emma Archer, Seema Arora, John Ashton, Jayanta Bandyopadhyaya, R.K. Batra, Mohit Bhargava, Rachel Biderman, Olle Björk, Sérgio Bresserman, Kerry Brown, Peter Czaga, Alan Chan, Brahma Chellaney, Raj Chengappa, Rita Roy Choudhury, Katarina Clifford, Solveig Crompton, Chandrashekhar Dasgupta, Brian Day, Luis Alfonso De Alba, Nitin Desai, Caroline Dickson, Gina Downes, Harald Dovland Tasneem Essop, Fábio Feldmann, Thomas Garner, Francois Godement, Fred Goede, Laurence Graff, Lance Greyling, Joydeep Gupta, Christer E. Hammarlund, Art Hanson, Paul G Harris, Görild Heggelund, Emi Hijino, Niels Junker-Jacobsen, Sivan Kartha, Amy Kazmin, Farieda Khan, Israel Klabin, Sonja Klinsky, Ulrik Lenaerts, Bernice Lee, Lars-Erik Liljelund, Simon Long, Fernando Lyrio, Anton Marin, Annika Markovic, Andrew Marquard, Ritu Mathur, Ivan Mbirimi, Guy Midgley, José Miguez, Chris Moseki, Jennifer Morgan, Jeanne Ng, Enn Ngcobo, Marjo Nummelin, PAN Jiahua, Varad Pande, Marc Pallemaerts, Kirit Parikh, Carol Paton, Jonathan Pershing, Linda Phalatse, Luiz Pires, Wendy Poulton, Felix Preston, Garreth Price, Lavanya Ra- 
jamani, Adriana Ramos, Rajani Ranjan Rashmi, Suzana Kahn Ribeiro, Carlos Rittl, Damian Ryan, Mohammed Reza Salamat, Geoffrey Rudd, Donald Sawyer, Steve Sawyer, Roberto Schaeffer, Nitin Sethi, Shirish Sinha, Richard Shackelton, Andrew Small, Matthew Stilwell, Maurice Strong, Mr V. Subramanian, SUN Zhen, Alex Tancock, Staffan Tillander, Håvard Toresen, Jukka Uosukainen, Richard Worthington, John Yeld, Carlos Eduardo Frickmann Young, William Yu, and Carolin Zeger.

We are particularly grateful to the following reviewers for spending considerable time to read and comment on the final draft manuscript:

Steinar Andreasen, Bo Kjellén, Hans Verolme, Sergio Abranches, Suraya P. Sethi, YAN Shuangwu, Guoyi Han, John Forgash, Marion Davis, Robert Watt, and Harro van Asselt.

Lastly we would like to thank the Nordic Working Group for Global Climate Negotiations, the Swedish International Development Cooperation Agency and the Swedish Ministry of the Environment for generously providing financial support for this study.

The authors have worked collectively in this research and share the responsibility for the final analysis, conclusions and views expressed in this work. Appendix A provides an account of the methodological approach of our research

Stockholm, Helsinki and Brasilia, August 2011

Team of authors:

Karl Hallding

Marie Olsson

Aaron Atteridge

Antto Vihma

Marcus Carson, and

Mikael Román 


\section{Summary}

Carried by the weight of their increasing economic and geopolitical influence, the BASIC countries - both individually and collectively - are rapidly moving to the centre stage of international politics. Their increased influence in international climate diplomacy was clearly seen for the first time at the Copenhagen Climate Conference (COP15). The four appeared to have a joint strategy, and played a key role in negotiating the conference's final political outcome - the Copenhagen Accord - with the United States.

The emergence of the BASIC group just before COP15 was largely a response to external pressures. The rise of these countries in world economic and political affairs, and the fact that they have rapidly increasing emissions, has generated strong pressures from industrialised countries for them to accept obligatory greenhouse gas emission reductions. These pressures target the larger emerging economies, particularly China and India. Two clear examples of the carrot-and-stick approach being used to apply such pressure are their invitations to participate in the Major Economies Forum on Climate and Energy and the G8 plus 5 Dialogue on Climate and Energy.

The foundation of the BASIC cooperation can be traced back to a common "third world" identity formed during several decades in the G77 group of developing countries, in which the four BASIC countries have each played leading roles. The BASIC countries have also been working together in different constellations outside the climate negotiations for more than a decade. For instance, India, Brazil and South Africa work together within the IBSA Dialogue Forum with a broad agenda to reform the United Nations Security Council. Similarly, Brazil, Russia, India, China and South Africa have come together as BRICS with the goal of counterbalancing US dominance in the world economy. This suggests that while BASIC ostensibly deals with climate change, its raison d'être may well be broader. A more encompassing agenda could mean that the countries might disagree on some climate change issues, yet continue their collaboration for the foreseeable future. 
While they sometimes work together, the BASIC countries must be understood as four separate entities with their own policy priorities and strategies. Different norms and ideas, material concerns and relationships affect the stance that each country brings to the negotiation table, and these in turn shape the substance of BASIC cooperation, explaining why they partner on some issues but not on others. An example of this was seen at COP16 in Cancun when India collaborated with countries other than the BASIC group to have the phrase "equitable access to sustainable development" inserted into the Shared Vision part of the negotiation text.

One commonality among the four countries is the fact that each has made a pledge under the Copenhagen Accord that amounts to a significant deviation from business as usual emissions. Particularly in Brazil and China, these pledges are supported by domestic legislation through policies to promote development, energy security and environmental qualities. These policies also have positive climate co-benefits, which have moreover helped establish dynamic clean technology sectors.

Since COP15, BASIC ministers responsible for climate-related issues have met quarterly, suggesting that the group is committed to continued cooperation. From the joint statements issued after the meetings, two clear patterns emerge: first, a call for a second commitment period of the Kyoto Protocol; and, second, an effort to build bridges with and show support for the rest of the G77. The discussions thus seem to generate agreement on a few broad principles, but have so far been unable to settle the finer details needed to articulate concrete contributions for the international negotiating process.

One issue on which the BASIC countries have been working to find a common position on is equity, and how the remaining carbon space should be shared between countries. A handful of technical-level workshops on equity have been held in conjunction with the quarterly highlevel meetings, but it appears that reaching consensus has been difficult. One of the main reasons for this is the diversity of views held by the countries themselves. India favours a per capita approach, Brazil and China prefer historical emissions and South Africa favours a mixture which also takes capacity into consideration.

The lack hitherto of a common agenda has led some observers to argue that the BASIC countries are ultimately an "obstructive grouping" that can agree only on avoiding mandatory international emission reduction com- 
mitments for as long as possible. While this may be a part of their shared agenda, such an argument is simplistic and misses the fact that finding a joint agenda between four countries as diverse as the BASIC countries is very challenging, and that the intricacies of the climate negotiations are tightly tied to other areas of both domestic and international politics that must be juggled simultaneously.

There are, however, signs that some BASIC countries are unilaterally helping to bring about convergence on global solutions. The role played by India in brokering an agreement via the needs-based concept "equitable access to sustainable development" at COP16 in Cancun was widely hailed as constructive in the international media. ${ }^{1}$ This does not, however, appear to have been a joint coordination effort between the BASIC group, suggesting a pattern - at least for now - in which individual BASIC countries are more likely to bring about solutions than the collective.

In that light, BASIC may well prove to have been a temporary constellation that served a particular purpose at a very important juncture. In particular, China's growing dominance could make it a challenging partner for the other three. There could also be opportunities for any of the BASIC partners to maximize broader diplomatic and geopolitical benefits through other relationships. Regardless of what direction their joint future takes, the BASIC countries are countries on the rise in the international system and will continue to occupy a larger space both in climate diplomacy and elsewhere.

\footnotetext{
${ }^{1}$ In a nutshell, the concept "equitable access to sustainable development" is generally considered more pragmatic than the formerly used "equitable access to carbon space". This is largely due to the former being needs-based while the latter is rights-based.
} 



\section{BASIC takes the stage}

It has become almost a cliché to note that the outcome of the fifteenth session of the Conference of the Parties to the United Nations Framework Convention on Climate Change (COP15) in Copenhagen was neither what was hoped for nor what was expected. When the waiting lines had finally disappeared from the icy streets around the Bella Centre, the street demonstrations quietened and the leaders retreated to their capitals, the world was left to make sense not only of the three-page agreement that was the Copenhagen Accord, but also of a new international constellation between Brazil, South Africa, India and China - BASIC - that had firmly taken the stage.

One month earlier, in a spirit of raised expectations for a grand deal, few had imagined that the only deal to be had in Copenhagen would be struck by the BASIC countries and the United States, with the European Union (EU) playing a less clear role. As this report chronicles, however, cooperation among the BASIC countries has a history that is rooted in a shared Third World heritage and the relations that have developed between the individual BASIC countries as fellow travellers on the road from poverty to increased wealth and a growing status in world affairs.

This report is driven by the conviction that the way in which the BASIC cooperation develops will have enormous implications for the success of future climate negotiations. It seeks a deeper understanding of the wider economic and political influences that brought the BASIC partners together, and that drive their unity or disunity in the climate arena. The analysis builds on a notion that climate policy developments in each of the countries are constructed from a unique mix of ingredients that are currently driven at least as much by development imperatives and the need for energy security as by climate concerns. These internal drivers naturally shape the negotiating positions each country brings to the United Nations climate negotiations. At the same time, these four emerging powers each have a wider foreign policy envelope and ambitions for a greater voice in 
international affairs that play a decisive role in conditioning negotiating strategies.

\section{Why study the BASIC countries?}

The BASIC countries play an increasingly large role in international politics in general and climate negotiations in particular. Understanding the motives that drive them and how they themselves regard climate cooperation is crucial for anyone who wishes to engage with them more effectively. A deeper understanding of BASIC in the context of the climate arena also goes hand in hand with a quest - particularly among Northern policymakers - to understand the broader shifts in global economic and geopolitical power.

Since the Copenhagen meeting, many have seen BASIC as a reactive force, but this oversimplifies its role. By coming together in a group of their own, these emerging economies are distinguishing themselves from both industrialised and poorer developing countries. Nonetheless, they are keen to voice their allegiance with the wider group of developing countries (G77) 2 collective, for which they provide important negotiation leverage vis-à-vis the industrialised countries. The way in which the BASIC countries position themselves reflects the fluidity of their position between developing and developed countries.

Although they sometimes work together, the BASIC countries are four individual entities with different policy priorities and strategies. This leads them to be partners on some issues but not on others. A better understanding of what these issues are - and how they fit with the countries' individual perspectives - could lead to more successful negotiation outcomes.

\footnotetext{
${ }^{2}$ China is not formally a member of the Group of 77, but it is a very close "associate" or "invitee". In the climate talks, China negotiates within the group, and thus in the United Nations Framework Convention on Climate Change (UNFCCC) the group is referred to as the "G77 and China". This report refers to the G77, for reasons of readability.
} 


\section{BASIC on the eve of COP15}

When the BASIC countries appeared on stage on the eve of COP15 they had been converging with each other for a decade in areas such as trade relations and demanding more say in international institutions. Nonetheless, these are four very different countries with competing interests and, on certain issues, strong rivalries. Three keys were therefore essential to unlocking the space for the BASIC group to come together in the way it did before COP15.

The first key was the partial improvement in Chinese-Indian relations that built on the increased cooperation on energy and climate issues since the mid 2000s. ${ }^{3}$ The long-standing rivalry between China and India mostly related to the two Asian giants' conflicting regional security interests - had made closer coordination on global issues difficult. Now that the two countries shared development-related energy security challenges, however, and faced similar global pressures to limit the environmental impacts of their development, they saw opportunities to work together on climate diplomacy. The research behind this report points to China and India as the more active parties in the BASIC constellation, and most people consulted believe that China has the most to gain from the BASIC cooperation and would probably have acted as both architect and leader. One centrally placed source, however, argues that India played the initiating role before COP15 (see section 4.3 below). ${ }^{4}$

The second key was the mounting pressure which these countries experienced in the run-up to COP15. As is detailed in Chapter 2, the four BASIC countries had been singled out by the leading economies in the North to participate in forums such as the G8+5 Climate Dialogue and the Major Economies Forum on Energy and Climate (MEF) to discuss mitigation on more equal terms with developed countries, without the protective shield of the Climate Convention's "common but differentiated responsibilities." At the same time, the voices of poorer and more vulnerable developing country were also beginning to urge "large developing coun-

\footnotetext{
${ }^{3}$ See Siddiqi (2011).

${ }^{4}$ Discussion with a senior diplomat from a BASIC country, June 2011.
} 
tries" to take responsibility for limiting their emissions. ${ }^{5}$ Because all the BASIC countries were keen to be seen as responsible global stakeholders, a combination of escalating pressure and a wish not to be blamed for the failure of COP15 provided strong incentives for them to seek a joint strategy before Copenhagen.

The third key was the strong sense among the BASIC countries - and China and India in particular - that an "ambush" had been set by the EU in collaboration with the United States by proposing a political deal known as the "Danish Text". As is discussed in section 5.2, conditions which put developing countries at a disadvantage - particularly the 2050 targets and a suggested year for peak global emissions - made China and its BASIC partners feel it was impossible to sign on to the Danish Text Worried about the risk of getting the blame, the BASIC group allegedly agreed on a strategy to "peel off the United States from the EU."6 The strategy was successful in that a final deal - the Copenhagen Accord - was struck between the BASIC countries and the United States without 2050 targets, and with a clear distinction between developed countries' and developing countries' conditions for the measurement, reporting and verification of mitigation efforts. The fact that China, and to a certain extent India, was nonetheless heavily blamed for sabotaging a Copenhagen deal is a less successful aspect of the BASIC story. ${ }^{7}$

\section{What future for BASIC?}

The outcome of COP15 raises crucial questions about the extent to which the BASIC countries acted as blockers to and/or facilitators for a deal that went as far as was politically possible at the time. The Copenhagen Accord is clearly far from what is needed in terms of ambitions either to mitigate emissions or provide finance and technology to developing countries. Nonetheless, it was the first time that a number of major emitters made any sort of international declaration of intent to curb their emissions. In addition, through its bottom-up approach, the Accord is increasingly being

\footnotetext{
${ }^{5}$ See Hallding, Han and Olsson (2009a, p. 14).

${ }^{6}$ Discussion with a senior diplomat from a BASIC country, June 2011. See also Vidal, (2009).

${ }^{7}$ See, e.g., Lynas (2009); and Rapp, Schwägerl and Traufetter (2010).
} 
seen as a reasonably good first step towards building trust for future negotiations. The BASIC countries played a key role in making it happen.

A number of questions arise. What kind of role will the BASIC countries as a group or individually - play in future negotiations? Will they stay together? Will they continue as a largely reactive group or take a more proactive role, perhaps finding a viable solution to the equity conundrum and an update of the concept of common but differentiated responsibilities?

To contribute to our understanding on these questions, this report traces the origins of BASIC cooperation on climate issues in Chapter 2, reviews the climate-related policies and diplomacy of each of the BASIC partners in Chapter 3, sheds light on the broader geopolitical context in which the BASIC cooperation emerged in Chapter 4, and analyses the key issues and possible visions that might guide future BASIC cooperation in Chapter 5. Chapter 6 summarises the key trends and developments observed in this report. 



\section{The origins of BASIC: Developing country roots and the image of emerging powers}

\subsection{Out of the shadows}

Many seasoned observers expressed surprise at the appearance of and unity displayed by the BASIC group during the Copenhagen conference. ${ }^{8}$ In the decisive days of Copenhagen, the four countries held coordination meetings on "an hourly basis". 9 Tight, functional cooperation in the heat of COP15 displayed a different level of unity than the more commonplace South-South climate diplomacy, which has tended to issue generally worded joint statements before a conference.

The BASIC countries stressed that they remained firmly anchored within the G77 group of developing countries and the President of the G77 supported that claim..$^{10}$ Nonetheless, by publicly presenting themselves for the first time as distinct from the rest of the G77, this clearly marked a new development in climate politics. Did this new development stem from a sudden sense of common threat felt by these four emerging economies? Or was it motivated by a sense of opportunity by one or more of the four to chart a different path?

Climate negotiators from the BASIC countries have been routinely cooperating as an informal subgroup within the G77 since at least the mid-

\footnotetext{
${ }^{8}$ Interviews with senior diplomats from the BASIC countries, Europe and the Americas, October 2010. ${ }^{9}$ Indian Environment Minister Jairam Ramesh, Lokh Saba of the Indian Parliament, 21 December 2009. 10 See Dasgupta (2009).
} 
2000s, jointly analysing developments in the United Nations Framework Convention on Climate Change (UNFCCC) process and working on common strategies. ${ }^{11}$ This cooperation evolved partly out of the greater capacity these countries have among the G77 for analysing the increasingly complex developments in climate diplomacy, and partly from the introduction of the phraseology on "more advanced developing countries", "major emitters" or "emerging economies", which was seen as a common threat. ${ }^{12}$ Sino-Indian cooperation on climate diplomacy has its roots in the 1990s and has continued formally and informally, as demonstrated by the Sino-Indian Memorandum of Understanding on Climate Change published in October 2009.13

Some have drawn the conclusion that the BASIC group really came together as a reaction to the so-called Danish Text - an early, draft version of what later became the Copenhagen Accord.14 While this may have sparked the joint position announced just before COP15 and intensified coordination during the meeting, the ability of Brazil, South Africa, India and China to come together at this critical moment had its origins in a pattern of longer term cooperation.

A broad perspective is required to understand the emergence of BASIC. On the one hand, there is the membership and tradition of the G77, in which all four have played key roles for decades and within which strands of a common identity have been formed. Another key insight is the increasing rise of these countries in world economic and political affairs (to be further elaborated in Chapter 4). This has triggered concerted efforts by industrialised countries to impose obligations on the BASIC countries, particularly China and India, to curb their growth in greenhouse gas emissions and increase the transparency of their climate policies within the framework of a global climate agreement. Together, these two contexts help explain the bonding of BASIC at COP15 and since.

\footnotetext{
11 Interview with a senior diplomat from a BASIC country, November 2010.

12 Interview with a senior diplomat from a BASIC country, June 2011.

13 See Devraj (2009).

14 Interview with two senior European diplomats, June 2009.
} 


\subsection{Normative roots in the G77}

Brazil, South Africa, India and China are all leading members of the G77, the developing country bloc in global negotiations, and their approach to climate negotiations is still heavily influenced by this shared history.

The G77 is a product of the political economy of the North-South divide in the 1950s and 1960s. At this time, many countries in the Global South were gradually coming loose from their colonial associations and looking optimistically towards a future of rapid social and economic development. However, the politically charged atmosphere of the Cold War was not particularly sensitive to developing country concerns, and many Southern countries found themselves facing structural disadvantages that contributed to a worsening of the terms of trade. A campaign to establishing an International Trade Organisation as part of the Bretton Woods structure was unsuccessful, leaving poorer nations dependent on trading primary products without a regulatory body to represent their interests.

It was against this backdrop of Southern disquiet that developing countries pushed for the establishment of the United Nations Conference on Trade and Development (UNCTAD) in 1964. ${ }^{15}$ At UNCTAD, a new solidarity bloc within the Third World contingent was formed with 77 founding members under the name of Group of 77. Over the years, membership of the group has grown to accommodate over 130 members, and its concerns and activities have widened far beyond UNCTAD, in which the group no longer plays any role.

An environment-development dichotomy has long characterised the G77's approach to global environment and climate negotiations. It surfaced at the dawn of global environmental governance, at the UN Conference on the Human Environment in Stockholm in 1972. It was here that many developing country politicians, such as the Indian Prime Minister, Indira Gandhi, emphasised that developing countries must prioritise economic development over environmental stewardship, defining these as

15 For a detailed history of the formation of the G77 see Williams (1991); and Geldart \& Lyon (1981). 
inherently competing priorities. ${ }^{16}$ Since the Stockholm Conference, environmental law-making at the international level has mushroomed, and the G77 countries have seen many negotiating processes as serving an explicitly Northern agenda. ${ }^{17}$ The tension between environment and development subsided somewhat as the all-encompassing concept of "sustainable development" became the central mantra in the 1990s, culminating in the World Summit on Sustainable Development (WSSD) in 2002. However, the reality of negotiations, for example, within the climate regime graphically illustrated the stubborn persistence of the North-South divide.

The G77 has often been described as a reactive coalition within environmental negotiation processes. ${ }^{18}$ It has typically adopted the posture of a "low-key negotiating collective, maintaining a united stand without the need for much formal coordination" while offering "well-established arguments on a short menu of well-rehearsed concerns."19 Common demands include the need to link environmental and development objectives, the need for more financial and technological resources to support environmental programmes in developing countries, the need for capacity building for both negotiating and implementation, and the need for longer time horizons for the implementation of new regulations. ${ }^{20}$

As the nature of the environmental issues tackled by international forums has increasingly shifted to issues of global common property - ozone, biodiversity protection and climate change - this arguably created a greater concern and vested interests among developing countries that negotiations deliver meaningful outcomes. It has also given the South a stronger collective negotiating position, ${ }^{21}$ which has led to claims that it will use this leverage to strategically renegotiate economic, trade and debt issues in the spirit of the New International Economic Order. ${ }^{22}$ There are also concerns among

\footnotetext{
16 In her 1972 Stockholm Address, Prime Minister Gandhi elaborated: “...we do not wish to impoverish the environment any further and yet we cannot for a moment forget the grim poverty of large numbers of people. Are not poverty and need the greatest polluters?".

17 See, e.g., Vihma (2011a).

18 There are some notable exceptions to this, including the G77's proactive role in the UN Convention to Combat Desertification.

${ }^{19}$ Najam (2004, p. 153).

20 Williams (2005).

21 Miller (1995).

22 Rajan (1997, pp. 2-4).
} 
developing countries that industrialised countries are using environmental negotiations to protect their own economic interests against the rapid rise of emerging economies such as the BASIC countries. ${ }^{23}$

\section{Solidarity in the 677}

Solidarity among the G77 countries is built on three factors: it is an outcome of a mixture of rational interests, an identity dimension and institutional factors.

\section{Ideational roots: exclusion from world affairs}

The common identity within the G77 originated from a sense of inequality and of being peripheral to the world's political and economic systems. Even today, global power structures create conditions conducive to the formation of an identity based on a lack of access to meaningful participation in international decision-making. A consequent fear of exclusion creates a commonality of purpose and although the traditional notion of exclusion holds less and less currency for the BASIC countries, it resonates with small developing countries and results in positions that promote inclusiveness and consensual decision-making.

The threads of solidarity are linked with a worldview in which inequality is seen as a dominating feature. There is a normative agenda of Third World unity, sometimes referred to as "Third Worldism", which is carried into the climate negotiations. ${ }^{24}$ This feeds into perceptions of what a fair outcome would look like, and is usually linked to notions of the historical responsibility of the North and varying formulations of equal per capita rights to emissions or the environmental commons. This identity also explains a more general tendency to mistrust the developed world and to emphasise the need for a fair process for negotiations. ${ }^{25}$

\footnotetext{
${ }^{23}$ It is of course important to point out that the BASIC countries are not the only "emerging economies" operating in the UN system. Nor are the countries that share the label emerging economies identical. They are quite different domestically but share some characteristics in terms of their place in the international system.

${ }^{24}$ See Parks and Roberts (2008).

${ }^{25}$ See Vihma, Mulugetta \& Karlsson-Vinkhuuyzen (2011).
} 
In addition, political posturing with ideological and identity concerns, most notably along North-South lines, has always played a part in the climate negotiations, and has featured constantly in recent deliberations in the UNFCCC. On the G77 side, political leaders of the South are presented with an opportunity to score political points - for domestic as well as international audiences - by acting tough against the North.

The concepts of sovereignty and non-intervention are also shared norms and important elements of many developing countries' foreign policies, particularly for the many with roots in colonial histories. In China, for instance, the Century of Humiliation, a period that began with the First Opium War in 1839 and ended with Mao's rise to power in 1949, was marked by regular Western and Japanese intrusion, and still influences Chinese thinking about international relations. ${ }^{26}$

\section{Institutional and interest-based solidarity}

Solidarity is also helped by broader institutional inertia, or so-called path dependency. In relation to climate negotiations, the way in which the principle of common but differentiated responsibilities has been institutionalised in the Kyoto Protocol, ${ }^{27}$ as a firewall between developing and developed countries, is an important factor. The Convention divides industrialised and developing countries into two Annexes and makes no distinction between the membership of the large group of developing countries. Ultimately, this process was based on self-selection and not objective criteria. This explains how, for example, the wealthy Gulf monarchies and countries such as Singapore are annexed as developing countries along with members of the G77. The institutionalisation of common but differentiated responsibilities plays a significant role in the efforts of the BASIC countries to resist explicit differentiation, and also explains the concerted efforts of some industrialised countries to set aside the Kyoto Protocol.

It is also worth noting that the principle of common but differentiated responsibilities is open to several interpretations, not solely a clear Annex

\footnotetext{
${ }^{26}$ For an overview of Chinese perceptions of the international order see Kaufman (2010). See also Carlson (2011) for an overview of how this is beginning to change.

27 The Kyoto Protocol is a Protocol that in part operationalises the UNFCCC. It sets legally binding targets for 37 industrialised countries to reduce their greenhouse gas emissions.
} 
I and non-Annex I divide. This is a legitimate interpretation, but the Convention is far from univocal on the subject. "Common but differentiated responsibilities" is mentioned three times - in the Preamble, in article 3.1 and in article 4.1.28 Article 3.1 also emphasises "respective capabilities", and article 4.1 applies univocally to "all parties", not only to the developed country parties listed in Annex I.

Apart from the strands of common identity and shared norms, solidarity also has its interest-based value. The G77 has long-lasting common and rational interests, such as opposing donor dominance in international financing.

For smaller developing countries, the G77 has been important in creating bargaining power - although the strength of this claim is dependent to some extent on how negotiation positions are formed within the G77 itself. The group has a majority in the United Nations and its promotion of the one country, one vote principle helps explain the importance to developing countries of procedural issues and of keeping climate negotiations within the UNFCCC process.

For larger and more advanced developing countries, a broad coalition lessens the risk of being singled out for special treatment in the negotiations and in public debates. This point is often raised with direct reference to China. However, while the big developing country emitters are protected by the G77 collective, the bigger countries also provide leverage for the group as a whole. For instance, China regularly pushes for financial support to be mobilised for the G77 countries, while not claiming any for itself. ${ }^{29}$

\section{The seeds of diversity}

Finding common ground across a group as large and diverse as the G77 is not easy. Significant socio-economic diversity has existed within the G77 from the start, ${ }^{30}$ and economic differentiation widened further during the 1970s as the OPEC countries rapidly became wealthier and some newly

\footnotetext{
${ }^{28}$ See the UNFCCC text (UNFCCC), 1992.

${ }^{29}$ During COP15 in Copenhagen, Chinese Premiere Wen stated that "China would never compete with developing countries for even a single cent of financial support". See Zhao, Tian and Wei (2009).

30 Williams (2005).
} 
industrialising Asian countries reached middle income status. ${ }^{31}$ This process of differentiation among developing countries is ongoing, as countries such as China expand their economic interests and establish strategic investments in commodities and land in other developing countries in a way that looks rather like the pattern of industrialised countries before them. ${ }^{32}$

The negotiating positions taken by countries are influenced by a combination of their own national interests, for instance, in economic and security terms, as well as strategic international relationships. Differences in economic structures, levels of development, levels of greenhouse gas emissions and vulnerability to the impacts of climate change create conditions for diverging national interests, which naturally results in the emergence of opposing views on different individual issues within the negotiations.

Clear signs of G77 disunity were visible at the Copenhagen meeting, concerning for example the legal form, the level of ambition and the overall negotiating strategy. ${ }^{33}$ This fragmentation of interests within the G77 bloc arguably added more glue to bind Brazil, South Africa, India and China together. Fearing isolation - not least in the case of China and India, which were specifically singled out as examples of developing countries that would be expected to take on emission reduction obligations - and aware that their different interests and capacities as emerging economies distinguish them in some respects from the rest of the G77 group, the four countries gravitated towards one another and towards a desire to present a "common front".

\footnotetext{
31 Braveboy-Wagner (2009, pp. 7-8).

32 The Financial Times estimates that the China Development Bank and Exim Bank lent at least USD100 billion to developing countries in 2009-2010 (Dyer, 2011). Recent analysis suggests that Chinese lending also involves conditionalities (in a broad sense) for its developing country partners, even if these are not imposed explicitly by a unitary state actor. (Mattlin \& Nojonen, 2011).

33 See Vihma (2010).
} 


\subsection{The growth of BASIC}

The BASIC countries have only recently become visible as a group in the climate arena, but the individual countries - along with other emerging economies - have been increasingly visible in wider global politics for some time, both in broader economic terms and in terms of the social, political and economic effects of climate change.

\section{A weighty group}

The four BASIC countries represent roughly $40 \%$ of the world's population, and each is indisputably a regional power. South Africa's economy contributes around 31\% of sub-Saharan Africa's total Gross Domestic Product (GDP), and Brazil 38\% of GDP in Latin America and the Caribbean. India, home to around $17 \%$ of the world's population, accounts for $80 \%$ of GDP in South Asia, and China, with a population about 200 million more than India's, for 35 per of GDP in the East Asia and the Pacific region. China is the world's largest greenhouse gas emitter (in total annual tonnes), has a permanent seat on the UN Security Council and is a developing country superpower.

The four together accounted for 12\% of global GDP in 2009.34 Their collective share of global trade has grown significantly, to $12.6 \%$ of world merchandise exports and $7.6 \%$ of commercial exports in 2009.35 Since the early 1990s, the BASIC countries have all enjoyed higher than world average rates of economic growth, and higher growth rates than the USA or the EU, led by China and India with average annual GDP growth since 2000 of $10.2 \%$ and $7 \%$, respectively.

\footnotetext{
${ }^{34}$ Based on data from the World Bank (World Development Indicators \& Global Development Finance, 2010).

${ }^{35}$ Based on data from the WTO statistics database (Trade Profiles, 2010).
} 


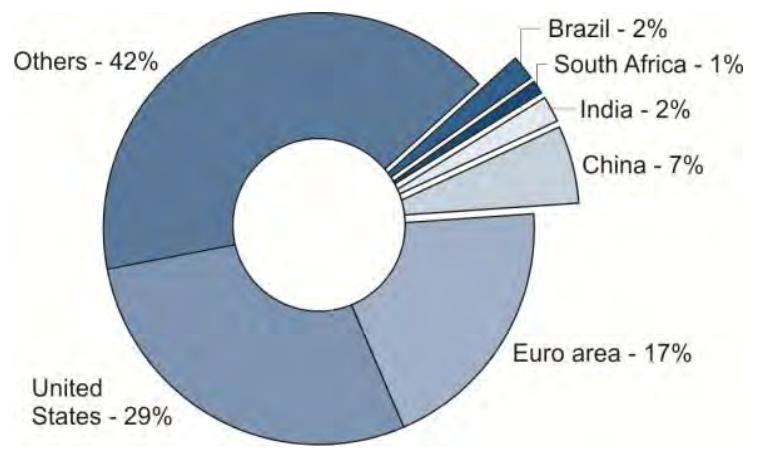

Figure 2.1: BASIC contribution to global GDP, 2009.36

It is not only their economic rise that has marked them out as industrialised countries. Figure 2.2 presents four ways of looking at the BASIC countries' contribution to global greenhouse gas emissions. In 2007, the four BASIC countries collectively accounted for nearly $60 \%$ of total annual greenhouse gas emissions from non-Annex 1 countries, 37 and around 29\% of total global emissions - of which China alone made up around $17 \%$.

Per capita emissions remain low in India, but the rate of growth in these emissions is high. What sets China, India, Brazil and to some extent South Africa apart in the climate negotiations is their projected rates of growth in total emissions.

36 Based on data from the World Bank (World Development Indicators \& Global Development Finance, 2010).

${ }^{37}$ From figure 16 in World Energy Outlook (International Energy Agency (IEA), 2009). 


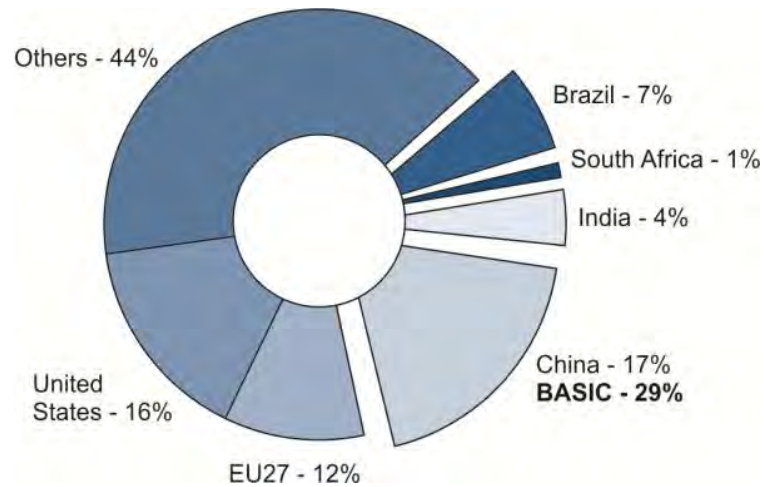

Figure 2.2a: Total greenhouse gas emissions, 2005. (all gases, including land use change and forestry).

Source: World Resources Institute, CAIT 8.0.

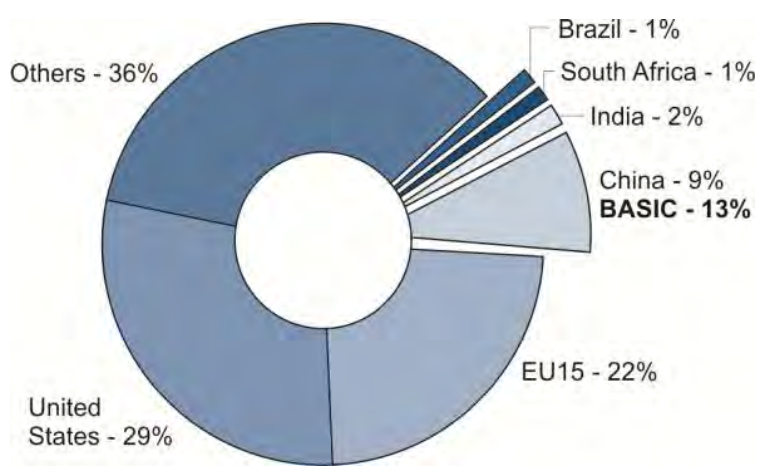

Figure 2.2b: Cumulative (historical) $\mathrm{CO}_{2}$ emissions to 2007. Source: World Resources Institute, CAIT 8.0. 


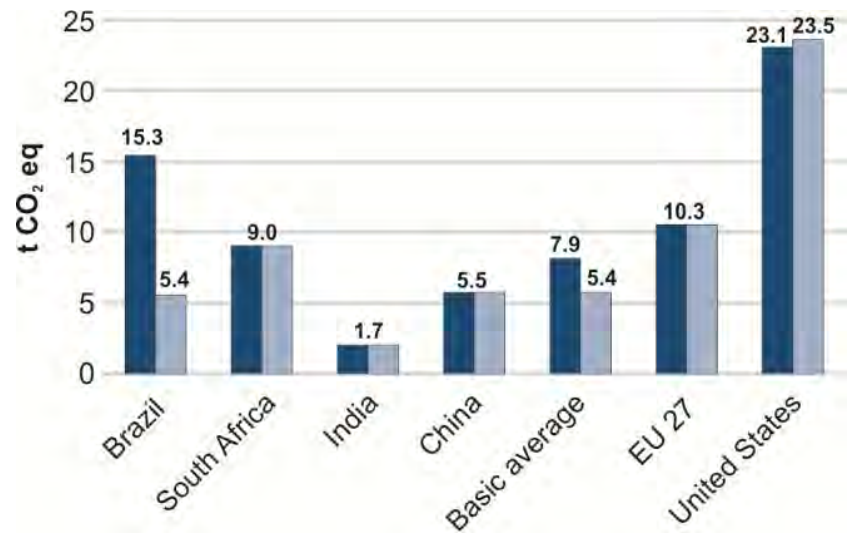

Figure 2.2c: Per capita emission 2005, left column includes land use change and forestry.

Source: World Resources Institute, CAIT 8.0.

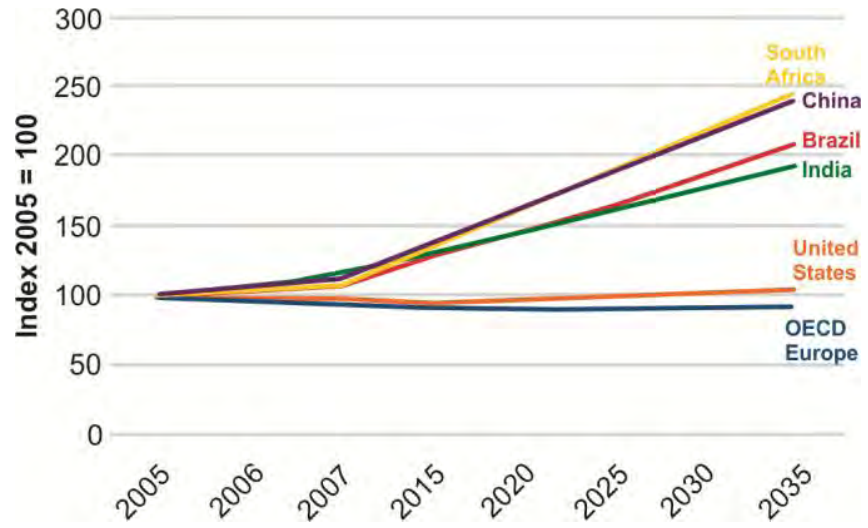

Figure 2.2d: $\mathrm{CO}_{2}$ proportional projections to 2035.

Source: US Energy Information Agency (2011); International Energy Outlook 2010, Table A10; and Winkler, H. (2007), Long-term mitigation scenarios: Technical report.

\section{Distinguishing BASIC from the G77}

As a response to the growing prominence of Brazil, South Africa, India and China on the world stage, the countries began to be variously labelled "major economies", "major emitters" and "advanced developing countries", distinguishing them from other developing countries. They also began to be distinguished on the basis of their greenhouse gas footprints. An article by 
Todd Stern in 2007, prior to his appointment as US Climate Change Envoy, asserted that the Kyoto Protocol's exemption for developing countries was "no longer sustainable for the more advanced developing countries." 38

The industrialised countries began to shift the climate dialogue to outside the UNFCCC process. In 2005, the BASIC countries plus Mexico were invited by the G8 president to participate in the G8 plus Five Dialogue on Climate and Energy (G8+5), ${ }^{39}$ which brought together the world's 13 largest greenhouse gas emitters. This G8 Dialogue is ongoing, but has gradually merged into the G20 (major economies) format, thereby increasing the number of stakeholders. The BASIC countries have also been invited to participate in the US-initiated Major Economies Forum on Energy and Climate (MEF). 40

These institutional shifts reflect a growing international view that major emerging economies must play an important role in combating climate change. The agreement by BASIC countries to participate in these new forums could be seen as reflecting a willingness to discuss efforts to tackle rising greenhouse gas emissions on equal terms with major developed country emitters. Other foreign policy goals, however, are likely to have been important motivators for them to join, as attempts to shift parts of the debate outside the UNFCCC represent a threat to these four countries. ${ }^{41}$

Within the UNFCCC process there are agreed - albeit somewhat vague - principles, around which an international agreement is expected to be negotiated. ${ }^{42}$ In the new forums that bring together "major emitters" on equal terms, however, no formal written principles have been agreed.

\footnotetext{
38 Stern and Antholis (2007, p. 179). Importantly, this thinking is not new, but can be traced back to the Byrd-Hagel resolution passed by the US Senate in 1997. The resolution stated that the United States should not be a signatory to the Kyoto Protocol, and was passed by a 95-0 bipartisan majority. 39 The BASIC countries plus Mexico were first invited to participate in a dialogue on climate change in the G8 forum by the then British Prime Minister, Tony Blair, in July 2005. The summit was held in Gleneagles, Scotland. All parties present signed a plan of action to reduce emissions.

40 The MEF was launched by US President Obama in March 2009. It very much follows the logic of the Major Economies Meeting on Energy Security and Climate Change (MEM), set up under the Bush Administration in May 2007. It is thus a clear example of structural continuity across administrations even where some of the important goals for international climate cooperation are arguably different. Another example of this continuity is given in footnote 38 above.

41 Interview with senior European diplomats, June and October 2010; Interview with senior developing country diplomat, October 2010; Interview with senior BASIC country diplomat, June 2011.

42 See UNFCCC, article 3 (UNFCCC, 1992).
} 
There is no Kyoto Protocol to seek cover behind and there is no principle of common but differentiated responsibilities to which to refer. Thus, the MEF and G8+5 discussions, in separating the major emerging economies from other developing countries, are likely to have created an increased sense of exposure among BASIC countries already under some pressure in the UNFCCC talks. It is this that ultimately catalysed the need for a common response. 


\section{The BASIC countries}

The BASIC countries are not a homogenous set of emerging economies, but four separate individual nations with climate diplomacy determined by a unique set of domestic and foreign policy considerations.

This chapter sheds light on the drivers behind the BASIC countries' individual values and priorities in climate diplomacy, and presents a brief country profile of each of the four members. The content varies to reflect each country's circumstances, but the profiles take a similar approach, examining domestic and international climate policy determinants, locating climate diplomacy within broader foreign policy and using these determinants to explain the BASIC cooperation.

\subsection{Brazil}

Brazil has a long-standing interest in sustainable development and climate change issues. Since hosting the UN Conference on Environment and Development (UNCED) in Rio de Janeiro in 1992, at which the Framework Convention of Climate Change was originally signed, Brazil has remained an active and engaged partner in international climate change negotiations. This trend has been reinforced in recent years - most recently through former President Luiz Inácio da Silva's interventions at COP15 in Copenhagen.

Climate change has long been regarded by Brazil as primarily an international relations issue and has been managed under the auspices of the Foreign Ministry, with assistance from the Ministry of Science and Technology. The Brazilian position in the international climate negotiations has traditionally revolved around three issues: stressing every country's sovereign right to national development; opposing any suggestion that the Amazon rainforest be put under international control for its protection; 
and emphasising the historical responsibility and obligation of industrialised countries to compensate for their emissions to date. ${ }^{43}$

This stance, however, has gradually changed since COP12 in Nairobi in 2006, when Brazil for the first time expressed a willingness to discuss international agreements on forests. Since then, the country has made national commitments that go beyond any existing international agreements. These changes are explained by the new international context and, perhaps more importantly, by internal changes in the domestic political landscape.

\section{Domestic determinants: Land use-driven opportunities}

Almost half of Brazil's energy mix comes from renewable sources, which means it has a special position compared to most countries, particularly so in relation to its BASIC partners for which energy demand is a key determinant. As a consequence, the Brazilian economy has a comparatively low carbon profile of 5 tonnes $\mathrm{CO}_{2}$ equivalent in emissions per capita, ranking it 17th globally. If land use-related emissions are included, however, the picture changes dramatically, giving it $5 \%$ of global emissions and making Brazil the fourth-largest emitter after China, the United States and the EU. The per capita figure increases to 12 tonnes per year. ${ }^{44}$ This reflects the fact that agriculture and forestry play a major role in the Brazilian economy, with deforestation responsible for over half the country's current greenhouse gas emissions, and the fact that biofuels constitute a substantial part of its energy mix.

This also explains the mixed picture of where Brazil's emissions are heading. According to McKinsey, ${ }^{45}$ the opportunities from land use put Brazil among the five countries with the greatest potential to reduce emissions by 2030 - and at a comparatively low cost. Nonetheless, the Brazilian economy is projected to grow considerably, and the possibility of increased emission intensities raises questions about the future trajectory of Brazilian emissions.

\footnotetext{
43 For a more elaborate overview see, e.g., Trennepohl (2010).

${ }^{44}$ See Trennepohl (2010); and McKinsey \& Company (2010).

${ }^{45}$ See McKinsey \& Company (2010).
} 
Figure 3.1. illustrates the Brazilian energy mix as of 2009, with a large proportion of renewables and only 5\% from coal. Figure 3.2. illustrates the sources of Brazil's greenhouse gas emissions.

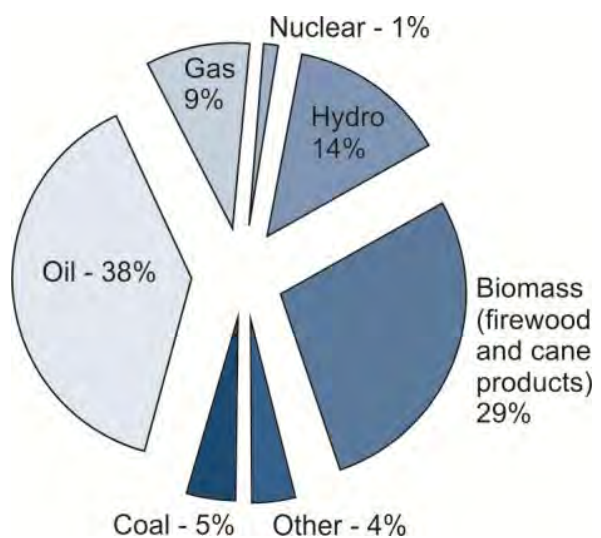

Figure 3.1: Brazil's energy mix 2009.

Source: Ministerio de Minas e Energia. 2010. Balanços Energéticos Consolidados Matriz 27 x 47 - Séries Históricas -1970 a 2009.

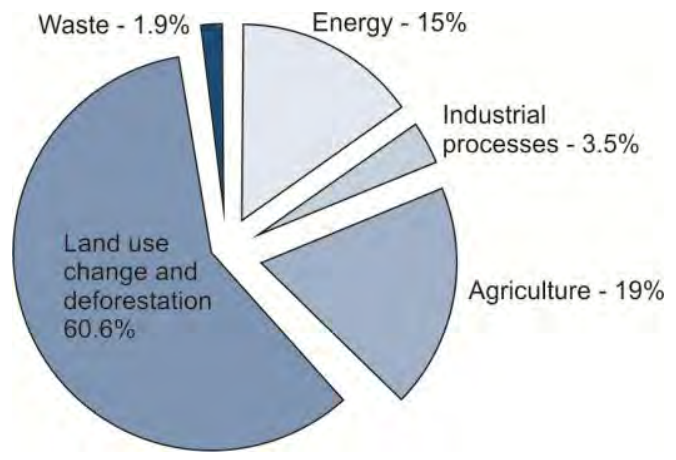

Figure 3.2: GHG-emissions by source, 2005.

Source: Coordenação-Geral de Mudanças Globais do Clima Ministério da Ciência e Tecnologia Brasília. 2010; Second National Communication of Brazil to the UNFCCC: Part 2, Table 2.9. (CO2e using GWP-100).Forestry and agriculture. 
The critical climate issue for Brazil is deforestation and consequent international demands to preserve the Amazon rainforest: $83 \%$ of its greenhouse gas emissions are derived from agriculture, land-use change and forest management. The success in controlling deforestation over the past decade is one of the pillars of Brazil's climate policy and a main reason for Brazil's ambitious pledge in the Copenhagen Accord to lower emissions by 2020 between 36.1 and $38.9 \%$ below business as usual. There are indications, however, that deforestation may start to rise once again, driven by changes to the Forestry Code which, if approved by the Senate and enacted, would put the whole climate change policy in jeopardy. ${ }^{46}$

A decisive factor is the political influence of the agricultural sector. After two decades of heavy investment in innovations in technology and farming practices, Brazil is a leading agricultural producer and exporter. In recent years, grain output has risen by half and the country is today the world's biggest exporter of orange juice, green coffee, sugar, ethanol, tobacco and the soya complex of beans, meal and oil. It is also the world's largest producer of beef and chicken. As a result, agriculture, including cattle ranching, is currently the second-largest source of emissions in Brazil (19\%). ${ }^{47}$

Under current carbon accounting schemes, agriculture and forestry are vital components of the Brazilian position in the international negotiations. Equally important are the strong political linkages between Brazilian agricultural interests and national climate change policies.

\section{A changing energy matrix}

Brazil distinguishes itself from the other BASIC countries - and from most developed countries - by having a comparatively clean energy system. More than $45 \%$ of Brazil's primary energy comes from renewable energy sources (31.5 \% biomass and $13.8 \%$ hydropower). In com-

\footnotetext{
46 IPEA, a Federal Government think-tank has just published an analysis showing that emissions reduction targets will not be met if these changes are approved.

47 Government of Brazil (2010).
} 
parison, the corresponding proportion for all countries is $12.9 \%$, and for OECD countries, $6.7 \% .{ }^{48}$

These differences are even more startling for electricity generation. Brazil produces nearly 73 percent of its electricity from hydropower. In addition, Brazil distinguishes itself by having a high proportion of biofuels in the transport matrix. Over $90 \%$ of new light vehicles are able to run on either ethanol or petrol.

However, the picture is changing. The Brazilian energy matrix is becoming increasingly carbonised, driven by several factors. The Brazilian economy is expected to continue its strong performance, with particularly rapid growth in carbon-intensive industrial sectors. As a consequence, energy-related emissions may double by 2030.49 Moreover, industrial development depends on high-carbon logistics: three-quarters of all merchandise is transported on diesel trucks. There may also be negative climate impacts on the capacity of the hydroelectricity sector and the production of biofuels. Finally, the discovery of what is potentially the world's second-largest oil reserve, the "pre-salt" offshore oil fields, could drive Brazil towards a more carbon-intensive transport sector.

This could lead to drastic changes in the Brazilian emissions profile over the next decade. The second national greenhouse gas inventory for Brazil shows that while emissions due to deforestation and land-use change rose slightly from 2000 to 2005, their share of total emissions dropped from 64 to $61 \%{ }^{50}$ Emissions from energy and industrial processes, meanwhile, rose by 9 and 10\%, respectively, to make up nearly $19 \%$ of total emissions - and they have risen by 51 and 43\%, respectively, since 1994 .

This means that Brazil's competitive advantage in a potentially carbon constrained global regime might be weaker than expected. To maintain this advantage, the country needs a new, low-carbon national development model and a climate negotiations outcome that supports its goals.

\footnotetext{
48 For more information about Brazil's energy production and consumption, see Ministério de Minas e Energia (MME) (2010).

${ }^{49}$ According to McKinsey \& Company's base case (2010).

50 Ministério da Ciência e Tecnologia (2010).
} 


\section{Climate effects}

Brazilians are also increasingly aware of the potential impacts of climate change on their country. ${ }^{51}$ Not only is there a growing middle class with the education and technical means to access and interpret climate information, but Brazil has in recent years been affected by several extreme weather events that have caused major material damage and human suffering. This has led to demands for concrete action in all sectors from every societal level. The discussions are not always explicitly framed in terms of climate policy, but few in Brazil question the existence of climate change.

A recent Brazilian investigation following the model of the Stern Report indicates that the total cost of climate change over the next 40 years will reach nearly 2.3 percent of GDP if nothing is done with respect to adaptation or mitigation. ${ }^{52}$ However, the more dramatic conclusion is that climate change will alter the premises for precisely those sectors - hydro energy, agriculture and bioenergy - that had been thought to give Brazil a competitive advantage in a future low-carbon world.

\section{New competitive patterns in industry}

The scenarios outlined above are creating new competitive patterns in Brazilian industry that under some circumstances could raise demands for additional climate action. The key in this context is efficiency in production. The phenomenon plays out both internationally and domestically.

At the international level, some Brazilian industries, such the cellulose industry and the mining industry, are relatively homogenous and comparatively efficient in a global competitive context. These are now to an increasing extent pushing the Brazilian government to bring about an international climate agreement that could lock in their respective global competitive advantages.

Similar demands driven by competitiveness drive calls for an upgrade of national climate policy in Brazil's agriculture sector. Following major investments in research and new land practices, Brazilian agriculture production increased by 365\% between 1996 and 2006. This expansion

\footnotetext{
51 See Hochstetler and Viola (2011).

52 See Margulis \& Dubeux(2010).
} 
led to major changes in the internal structure of the industry. New agroindustry actors with more efficient and sustainable production practices are now challenging the traditional large landowners (fazendeiros) that have dominated domestic markets. Just like its counterparts in the cellulose and mining sectors, the new agro-industry sees a comparative advantage in stricter climate change regulations and is pressing the government to pursue stricter policies. These structural changes within the agriculture industry - in which established interests are losing ground - could have far-reaching political consequences in the Brazilian Congress.

Finally, the "pre-salt" new oil and gas discoveries off the coast of Rio de Janeiro, with verified findings of nearly 30 billion barrels, ${ }^{53}$ will lead to enormous investments in research (equivalent of EUR 1 billion over the next two years), infrastructure and other related industry with major implications for the Brazilian economy as a whole. The Brazilian government has already declared that the oil resources will be used in a sustainable manner, and it has set up a special oil fund that, among other things, will provide financing for different climate initiatives.

\section{State and local strategic concerns}

States and other sub-national units in Brazil are also taking individual initiatives to address global warming. The most prominent example is the State of São Paulo, which in 2009 adopted a law requiring a 20\% reduction in greenhouse gas emissions by 2020 from 2005 levels. This is critical for two reasons. First, by adopting an absolute target with 2005 levels as the baseline, São Paulo exerts major pressure on the federal government, which for years has linked national targets (a 20\% reduction by 2020) to a business-as-usual scenario. The São Paulo state government is now actively considering the introduction of a local cap-and-trade system. Second, with nearly $40 \%$ of the country's economic activity, São Paulo is effectively Brazil's industrial heartland and economic powerhouse. This implies that the driver behind this active policy resides in some of the competitive arguments outlined above, along with serious concern about some of the environmental effects of climate change. More importantly from a policy

${ }^{53}$ See Webb (2010). More preliminary estimates suggest the existence of close to 80 billion barrels. 
perspective, however, São Paulo's sheer size makes it the standard setter for other states in the union. Some states, such as Rio de Janeiro and Minas Gerais, are now following in its footsteps.

The tendency towards local initiatives is not limited to industrial states. Interestingly, similar proposals can also be found in some key Amazonian states such as Pará, Amazonas and Acre, where state governments have committed to local deforestation reduction targets and elaborate plans to combat deforestation. The driving logic differs, however, from that of São Paulo insofar as the initiatives in the first instance seem to be more directed towards an international audience. Instead of using climate policy as a means of sustaining industrial competitiveness, the Amazonian efforts are directed at various international initiatives intended to finance the preservation of the Amazon rainforest. Over time, however, this has put pressure on the federal government to abandon its protectionist stance and instead push for international collaboration on forest issues.

\section{Climate-related policy: A changing political landscape}

The structural trends outlined above have recently led to changes in the political landscape. In the Presidential Elections in 2010, Marina Silva, the Green Party (Partido Verde) candidate and former Minister of Environment, gained almost $20 \%$ of the votes in the first electoral round. A large share of her support came from intellectuals and corporate interests, including agro-business, drawn to her vision of an alternative development model based on, among other things, ambitious climate policies. This may have contributed to pushing the two other main candidates - José Serra and, the eventual winner, Dilma Rousseff - to articulate their own climate programmes. The issue has remained at the centre of the national political agenda and President Rousseff has made an increasing number of references to climate change since taking office.

The Brazilian government has been stepping up its efforts on climate change for some time. In December 2009, the Brazilian Congress approved a new national climate change law, Plano Nacional de Mudanças Climáticas, which includes voluntary targets to reduce emissions by $36-$ 
$39 \%$ below business as usual by $2020 . .^{54}$ The goals largely mirrored existing policies, some of which were already having an effect. For example, the Brazilian government estimates deforestation rates for Amazonia to be at their lowest level since monitoring began. ${ }^{55}$

In addition, the government is making additional investments in both current and emerging sources of renewable energy, such as biofuels, hydropower and even nuclear power. These efforts are reflected in a series of administrative efforts, along with the creation of a domestic Brazilian climate change panel intended to coordinate rigorous scientific analysis of how climate change will affect Brazil and suggest options for mitigation and adaptation. Even with such progress, however, the federal government is under increasing pressure from multiple actors and interests to bolster its efforts.

\section{Climate diplomacy}

From the mid-1990s Brazil's climate diplomacy was largely guided by national self-interest as defined within the foreign policy envelope. Brazil positioned itself as an active spokesman for the developing world community, standing up for the fundamental right to development. Brazilian positions have included emphasis on the principle of common but differentiated responsibilities and capabilities, and support for the notion of historical responsibilities in burden sharing. Brazil initiated the idea behind and worked with the United States to develop and promote what became the Clean Development Mechanism (CDM), and played an active role in putting together the alliance between the EU, Japan and the emerging economies that made the Kyoto Protocol possible after the United States had pulled out. ${ }^{56}$

After Lula da Silva came to power in 2003 climate change was given a lower priority in the foreign policy portfolio, and the Lula administration focused on economic development. ${ }^{57}$ During the Lula presidency Brazil

\footnotetext{
54 See, e.g., Trennepohl (2010).

55 See, e.g., Hochstetler and Viola (2011).

56 Ibid.

${ }^{57}$ Ibid.
} 
has experienced remarkable development and strengthened its position as a regional power and developing world spokesman. Guided by Lula's vision of a grand South-South alliance, Brazil's foreign relations and trade policy took a more critical stance vis-à-vis the United States, at the same time as Brazil gained increasing stature in the Global South. The leading role played by Brazil in orchestrating the walkout by the G20 (developing nations) at the WTO Cancun Ministerial in 2003 is a telling example. (Described further in Section 4.2).

By the end of the decade, however, the domestic drivers discussed above - such as new actors motivated by a self-interest in stricter climate policy, increasing public awareness and success in controlling deforestation - began to affect climate diplomacy and led to a change to more proactive positions in the climate negotiations. In early 2009, Brazil endorsed the goal of holding global warming to $2^{\circ} \mathrm{C}$, and it has since suggested that industrialised countries agree to reduce emissions by $40 \%$ by 2020 . Brazil opposes binding reduction targets for non-Annex I countries, including the major emerging economies, but has pledged to voluntarily reduce emissions by as much as $39 \%$ from business-as-usual (this includes reductions from deforestation). ${ }^{58}$

Like other non-Annex I countries, including other BASIC countries, Brazil stresses financing and technology transfer from developed countries as key components of any future climate agreement, although it also envisages developing countries contributing to technology transfer. The latter reflects Brazil's interest in spreading its green technology - particularly for the production of sugar-based ethanol - but also reflects its ambition to be recognised as a responsible global power. Similarly, Brazil maintains that financing is not as important for it as for other developing countries, and that it will implement its own national climate plan regardless of any international climate agreement.

Brazil distinguishes itself from other BASIC countries by its strong emphasis on deforestation and land-use issues. Brazil has pushed hard for an agreement on reduced emissions from deforestation and forest degradation in developing countries (REDD), an area in which Brazil has a lot to 
gain in terms of mitigation and financing. Similarly, the country has stressed its achievements with biofuels. As is noted above, more than $90 \%$ of all new light vehicles there can run on either gasoline or ethanol. There are currently attempts to emulate the experience of the ethanol programme, known as Proálcool, in a National Programme for the Production and Use of Biodiesel. ${ }^{59}$

\section{The BASIC dimension}

Brazil's efforts over the past decade reflect its desire to establish itself as a rising power with a firm foundation in the South but growing capacity "to articulate its own interests and those of its allies at the international level."60

BASIC fits into the bigger picture of Brazil, under Lula's presidency, as the architect of a new kind of South-South cooperation. Brazil has actively nurtured collaboration with other emerging powers that have the ambition and capacity to play a growing role on the international stage. ${ }^{61}$ The IBSA Dialogue Forum (discussed further in Chapter 4) is one platform for building South-South relations, but IBSA is seen in Brazil as partly driven by India's interest in counterbalancing China. ${ }^{62}$ Lula saw closeness to China as a logical step in expanding Brazilian interests. Over the past decade, China has surpassed the United States to become Brazil's leading trading partner, accounting for roughly $15 \%$ of both exports and imports - an astounding increase from the beginning of the decade. ${ }^{63}$

Within BASIC, Brazil remains cautious and, in multiple ways, it is the "odd party" within the group. ${ }^{64}$ Its climate-related priorities differ considerably from those of the others - as has already been seen in some of the more technical discussions. Brazil's participation appears to be propelled by a growing awareness that it may well have to negotiate concrete targets and commitments soon, and thus it may be better off joining forces

\footnotetext{
${ }^{59}$ See, e.g., ibid.; and Trennepohl (2010).

${ }^{60}$ See de la Fontaine and Seifer (2010).

61 Ibid.

62 View suggested by Brazilian interviewee from research community.

${ }^{63}$ See Secretariat for Social Communication: International Area (2011).

64 The view that Brazil is the 'odd party' has been suggested in several interviews.
} 
with those in a similar situation to develop a joint agenda and shared priorities. While this dynamic is not likely to change, it may well be that a more activist Brazilian administration could have difficulties reaching agreement with the other members of BASIC due to the country's particular climate change priorities. Brazil could therefore be interested in joining other groupings if that served its purposes better.

In the long run, the level of BASIC cooperation is likely to be significantly influenced by other issues such as trade flows and other commercial concerns. There is, for example, a growing Brazilian concern about competition from low-priced Chinese consumer products, and the recent surge in Chinese investment in Brazilian commodities. The warming of Brazilian-US relations from late 2010 is at least partly induced by a common concern about what is seen as an undervalued Chinese currency. ${ }^{65}$ These broader tensions could spill over into the BASIC group's climaterelated cooperation.

Finally, Brazil plays an important role as convener of the Rio+20 summit, which will take place in June 2012. Although the Rio meeting has a broader sustainability agenda, it is likely that Brazil will see it as an opportunity to make progress on the climate agenda and as an chance to table joint BASIC proposals.

\subsection{South Africa}

Despite domestic constraints, South Africa's leaders have in recent years been able to engage constructively with international negotiations, and this seems likely to continue in their role as host to the seventeenth session of the Conference of the Parties to the UNFCCC (COP 17). This, however, presents an interesting diplomatic challenge since the goals of its international partners in Africa and further abroad do not always converge.

65 See reporting in the Financial Times, e.g., Leahy (2011a); and Pearson (2011). 


\section{Domestic determinants}

South Africa contributes around 31\% of the total GDP of sub-Saharan Africa. Owing to its abundant reserves of coal, its economy has attracted an array of large, energy-intensive industries. Consequently, its per capita greenhouse gas emissions are high by world standards and by far the highest in Africa.

At the same time, the country suffers from enormous levels of economic inequality. Its 2010 Human Development Index ranking of 110th in the world reflects the fact that much of the population is yet to benefit from the country's growing economy. Many people still have poor access to energy services, and addressing this energy access deficit - along with boosting employment - are among the highest political priorities of the country's leaders.

Energy is also the country's greatest challenge from a climate policy perspective. As is shown in Figure 3.3, the sector produced 78\% of the country's greenhouse gas emissions in 2000, a large part of which comes from electricity generation.

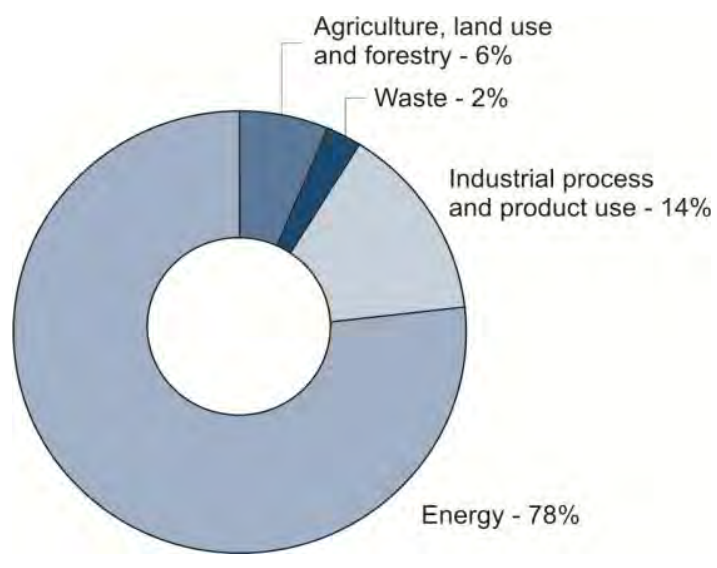

Figure 3.3: Sectoral breakdown of South Africa's greenhouse gas emissions, 2000.

Source: Government of the Republic of South Africa (2010). 


\section{Challenges to implementing domestic climate policy}

Some very real barriers at the domestic level work against the introduction of ambitious policies to tackle greenhouse gas emissions. Climate change barely registers as a political issue. There is little public awareness of or education about climate change, and few people actively participate in the policy process. Consequently, although several civil society organisations are visible in policy discussions, most of their efforts are focused on awareness-raising and highlighting links between the poverty/development and climate agendas. The media provides only sparse coverage of climate issues, and what attention there is still frames the debate as between climate scientists and "denialists".

A lack of engagement extends to the parliamentary arena, in which few voices raise climate issues at the national level. This is mirrored by the fragmented parliamentary oversight of relevant domestic planning processes, particularly the strategically important Integrated Resource Plan (IRP). As one parliamentarian notes, during 2010 the energy minister regularly postponed meetings of Parliamentary Energy Subcommittee at crucial stages during the development of the IRP, stifling political debate on key decisions about long-term energy planning that will have major implications for climate policy objectives. ${ }^{66}$

The ruling African National Congress (ANC) passed an extensive climate change resolution at its conference in 2007, which expresses general support for ambitious efforts to curb emissions and support cleaner energy. However observers have suggested that this is likely to have been pushed through the caucus by one or two individuals, and that climate change remains unimportant to the party. Indeed, there are signs of tension between climate policy and core ANC interests. The party has direct financial links to the planned Medupi power station, and the ANC Youth League seems eager to continue extracting revenue from the minerals sector. In September 2010, its leader called for the nationlisation of the country's mines using rhetoric linking fossil fuels with government objectives on addressing inequality.

66 Interview with South African politician, September 2010. 


\section{A strong link between industry and climate policy}

Even in the context of this inertia in public debate, powerful economic interests feel threatened by the prospect of an ambitious mitigation policy. South Africa's economy is built heavily around its natural mineral and fossil fuel resources, and abundant coal together with low electricity prices have attracted energy-intensive industries particularly in the metals sector. There are thus powerful industry actors with interests aligned with this minerals-energy complex.

In addition to the mining industry, one strategically important and influential industry player is Sasol, which produces liquid fuel from coal, and is the country's (and by some accounts the world's) largest point-source of greenhouse gas emissions. Its production is primarily for domestic consumers, making it an important factor in the domestic energy market. The highly specialised nature of Sasol's operations means that diversification in response to changes in climate policy is virtually impossible. The company is thus highly vulnerable to the introduction of an economy-wide carbon price, to the extent that many observers believe it would ultimately be offered a special exemption by the government were such a carbon price imposed. 67

The electricity sector, too, is of key importance to climate policy. The fact that many South Africans lack access to basic energy services is an important structural constraint, as is the fact that around $40 \%$ of available electricity is consumed by energy intensive (and politically influential) users in the mining and industry sectors. Low electricity prices have discouraged private investment in the electricity sector. This resulted in rolling blackouts across the country in 2008 that affected the mining and manufacturing sectors and reportedly caused the cancellation of large energy-intensive projects. ${ }^{68}$ This catalysed an urgent push from some industry sectors for new capacity to be built.

The electricity market is dominated by Eskom, a state-owned organisation and virtual monopoly player. As a response to the need for new supply, Eskom has advocated the expansion of coal-fired generation capacity, including the $4800 \mathrm{mw}$ Medupi power station. At the same time, the com-

\footnotetext{
67 This is a view expressed in several of the interviews. 68 See Clayton (2008).
} 
pany has been criticised for an institutional culture that is openly hostile to renewable energy and for making it difficult for independent power producers to enter the market with renewable energy supply.

The fact that domestic energy access and energy security are often discussed together and interchangeably in South Africa, along with Eskom's institutional bias towards fossil fuel-based energy sector expansion, create powerful drivers for greenhouse gas-intensive investments, making implementation of ambitious domestic climate policy challenging.

Both Sasol and Eskom are viewed as having close relationships with the government, and some observers suggest that they have more influence over South Africa's domestic energy policy than the Department of Energy. Eskom reports to the Minister for Public Enterprises, a more senior portfolio in the national cabinet than the energy ministry, and also has permanent representatives on the country's delegation to the UNFCCC.

\section{Labour and climate policy}

The link between industry and climate policy is not just about the corporate bottom line. Labour is also becoming a crucial factor. The unions have thus far been slow to engage with climate issues but they could potentially exert a constraining influence on climate policy, given the fact that their members work in the energy and minerals sectors. Black Economic Empowerment (BEE), introduced in 2007 as a central component of the government's strategy for tackling unemployment, is also a potential short-term constraint. The major BEE institutions are young, capital-poor enterprises and, while they are now woven into the minerals-energy complex, they are not yet present in the renewable energy sector. There is consequently little incentive among existing BEE players for a shift to cleaner energy.

\section{Climate policy in the bureaucratic sphere}

Responsibility for climate policy is an increasingly congested, if not contested, space in the bureaucratic sphere, and this presents its own challenges for coherent domestic policy implementation.

The Department of Environmental Affairs (DEA) has primary responsibility for both domestic policy development and the country's participation in international climate negotiations. In 2007 the DEA coordinated a Long Term Mitigation Scenarios (LTMS) modelling exercise involving academics, industry and government stakeholders as a basis for developing 
policy options to tackle greenhouse gas emissions. It also convenes the National Climate Change Committee, a forum for industry and other nongovernment stakeholders to discuss climate policy. In 2010 the DEA released a National Climate Change Response Green Paper, which proposes national strategies for mitigation and adaptation.

In December 2010, a Treasury discussion paper outlined options for an economy-wide carbon tax, arguing in favour of a tax imposed directly on measured emissions of $\mathrm{CO}_{2}$. Creamer has calculated that, "should carbon dioxide equivalent $\left(\mathrm{CO}_{2} \mathrm{e}\right)$ prices be set at [ZAR] R165/t, it could yield R82.5 billion in additional tax revenue for the South African government, given estimated total yearly emissions of about 500 million tons of $\mathrm{CO}_{2} \mathrm{e}^{\prime \prime} .{ }^{69}$ Unsurprisingly, major South African industries strongly oppose a carbon tax, citing concerns about international competitiveness. ${ }^{70}$ However, given the revenue potential that a carbon tax represents for a government drastically in need of funds for major investment in infrastructure and services, industry opposition may not be strong enough to discourage this course of action. There are also signs of recent efforts to improve the coordination of climate policy, such as the creation of the Intergovernmental Committee on Climate Change and the establishment in 2009 of the National Planning Commission. At the provincial/ municipal levels, various governments including Cape Town, Durban and Gauteng have developed climate plans. To date, however, provincial and municipal governments have had little influence over climate policy at the national and international levels, although there appears to be some upward push from the leading provinces, specifically on adaptation issues.

\section{Climate diplomacy}

South Africa has elements of a developing and an industrialised economy, and this dichotomy influences how the country approaches international relations, including climate diplomacy. A desire to present moral leadership, a neo-liberal view of both its own and regional economic develop-

\footnotetext{
${ }^{69}$ See Creamer (2011).

${ }^{70}$ Energy-intensive industries such as steel producer ArcelorMittal have branded the proposed tax a "nonstarter". Deloitte estimates that the proposed model could cost Eskom ZAR 37 billion per year in carbon taxes, Sasol around ZAR 9.9-billion per year, and ArcelorMittal about ZAR 1.7 billion per year (Creamer, 2011).
} 
ment and a desire to "engage and transform structures of power" are among the key driving norms. ${ }^{71}$ In multilateral settings, South Africa often adopts a "bridge builder" role, brokering cooperation both within the G77 and between industrialised and developing countries.

At COP15, the President of South Africa, Jacob Zuma, offered a voluntary greenhouse gas emissions reduction pledge - that the country would work to reduce greenhouse gas emissions to $34 \%$ below "business as usual" projections by 2020 - provided international financial support was made available. The pledge reflected one of the most ambitious scenarios from the country's climate change mitigation modelling exercise, and domestically it was seen as excessive and met with dismay. The pledge was also an exception to the more general rule that decisions on climate policy and on the country's approach to international negotiations typically originate within the bureaucracy rather than the political sphere. At Copenhagen, it was the President's office which decided both to offer a pledge and the scale of that pledge. This, combined with South Africa's overt efforts to show leadership, suggests that broader foreign policy objectives may be behind the country's international climate diplomacy.

\section{South Africa and Africa}

South Africa's foreign policy is a product of the "pressures, responsibilities and obligations that emanate from its structural location on the African continent", 72 and its relationship to and role within the continent is complex. There are important economic linkages, and the Southern African Development Community (SADC) is a major trading partner. However, South Africa also emphasises that its relations with other African states extend beyond purely economic ties and include support for building regional peace and stability. Former president Thabo Mbeki used the country's membership of the UN Security Council in 2007-2008 to "advance and consolidate the African agenda". South Africa has also helped drive the creation of multilateral institutions such as the African Union and the New Partnership for Africa's Development (NEPAD). ${ }^{73}$

\footnotetext{
${ }^{71}$ See Habib (2011).

72 Ibid.

73 See Mantzikos (2010).
} 
In global negotiation processes, including on climate change, the rest of Africa often relies on South Africa's capacity to engage. ${ }^{74}$ However, South Africa's alignment with the BASIC group and its joint role at COP15 led to accusations of the betrayal of African interests. The recent invitation to join the BRIC (Brazil, Russia, India, China) forum is reportedly also an emerging source of tension - especially since South Africa courted BRIC by offering itself as a "gateway to Africa". ${ }^{75}$

\section{The BASIC dimension}

South Africa's participation in BASIC is consistent with a broader pattern of geopolitical alignment, which includes the IBSA forum with India and Brazil since 2003 and, more recently, BRIC. South Africa looks rather odd alongside the other BASIC countries, given its much smaller size and economic weight. In greenhouse gas emissions terms its smaller economy and population means its total annual emissions are lower than its BASIC partners, but it has a larger per capita footprint, and this creates a different notion of how "equity" and burden sharing might best be framed in an international agreement.

The most satisfactory explanation of what encourages South Africa to position itself next to China, India and Brazil is that BASIC is a vehicle for international recognition and clout. The country has been eager to portray itself as a strong and stable economy, and a partner for African investment. A "developing country identity" does not always suit this purpose, whereas cooperation with major emerging economies sends a signal to foreign investors that South Africa is in a different league.

BASIC, like IBSA and BRICS, also presents a challenge to the traditional power structures embedded in international institutions, which has been an overt ambition of South African leaders since Mbeki succeeded Nelson Mandela. The brand of nationalism embedded since Mbeki's presidency has "conditioned" foreign policy on the notion of South-South solidarity as well as the creation of alliances and institutions that can push for global reform. ${ }^{76}$

\footnotetext{
${ }^{74}$ See Unmüßig \& Cramer (2008).

75 See Van den Bosch (2011).

${ }^{76}$ Habib (2011) argues that the influence of South-South solidarity on South African foreign policy can be seen in what is often perceived externally as South Africa's support for "rogue powers" (e.g. Palestine),
} 
While BASIC may have broader geopolitical utility, this does not automatically mean it has strategic value for South Africa's climate negotiators as they work within the UNFCCC process. A protective alliance has some logic for India and China, each of which fears being left diplomatically isolated as the G77 fragments, but this is arguably not the case for South Africa, which is an active member of the Africa Group. Furthermore, South Africa showed at COP16 that it is willing to take positions in the UNFCCC negotiations that are not shared by its larger BASIC partners - its approach to the issue of a legally binding outcome from the negotiations on Long Term Cooperative Action (LCA) was opposed by both China and India.

The most amenable explanation possibly lies in the fact that, since around 2009, a new rhetoric has emerged in South African climate diplomacy about needing "carbon space". ${ }^{77}$ While such an argument is unlikely to garner great support from within Africa, given that South Africa contributes around $40 \%$ of the continent's total emissions, ${ }^{78}$ BASIC provides a group of peers for which this rhetoric is also important.

As the host of COP17, South Africa will want to maintain a leadership position, but the diversity of its international alliances may make this a challenge. This might partly explain why in the past decade South Africa's approach to international diplomacy has generally been characterised by a strong preference for conflicts to be resolved through multilateral institutions and "quiet diplomacy",79 a useful approach for softening possible perceptions that the country might be working against its key foreign policy partners. It also helps to build legitimacy for South Africa in the rest of Africa, where international political norms have been strongly influenced by a history of colonial intervention.

\footnotetext{
which has earned it great criticism internationally, and that "an early indication of the importance of power as a variable in conditioning foreign policy emerged when South Africa jettisoned its strategic relationship with Taiwan in favour of one with China".

77 See Sabinet Cape Town Office (2009).

${ }^{78}$ South Africa accounted for $38 \%$ of total African emissions from fuel combustion in 2008 (International Energy Agency (IEA), 2010).

${ }^{79}$ Landsberg (2010).
} 


\subsection{India}

India is home to around $17 \%$ of the world's population, and is the world's fifth largest annual emitter of greenhouse gases as of 2007. Rising emissions reflect a period of rapid economic expansion, with an average annual GDP growth rate of $7 \%$ since 2000 which dramatically eclipses the average rate of economic growth in the United States (2\%) and the European Union (1.5\%). ${ }^{80}$ Macroeconomic indicators and gross emissions figures, however, tell only part of the story. India remains deeply plagued by poverty, ranked 119th on the United Nations Human Development Index in 2010. Roughly $42 \%$ of the population lives below the national poverty line, earning less than USD1.25 per day in 2005. India's leaders therefore face enormous challenges.

India is highly vulnerable to the projected impacts of climate change, which means an international climate agreement with strong environmental commitments is clearly in the country's interest. The Fourth Assessment Report of the Intergovernmental Panel on Climate Change describes potentially devastating impacts on, for instance, water availability and agricultural productivity, as well as threats from land inundation and important habitat loss such as coastal wetlands. This social, economic and environmental vulnerability adds a further layer of complexity to what is already a complex array of interests that must be balanced by the Indian government when it joins international negotiations on climate issues.

\section{Domestic determinants}

India's per capita emissions are very low in comparison to other developing country economies. In 2007, India's total annual greenhouse gas emissions amounted to around 1.9 billion tonnes $\mathrm{CO}_{2} \mathrm{e}$. The emission intensity of India's economy was estimated in 2006 at $0.34 \mathrm{kgCO}_{2}$ per USD GDP (using "Purchasing Power Parity" 2000 prices), roughly equal to the emission intensity of the EU $27\left(0.33 \mathrm{kgCO}_{2}\right)$ and below the world average $\left(0.49 \mathrm{kgCO}_{2}\right)$.

\footnotetext{
${ }^{80}$ Based on data from the World Bank statistics database (World Development Indicators \& Global Development Finance, 2010).
} 
The bulk of emissions are from the energy sector, as is shown in the sectoral breakdown presented in Figure 3.4. The expansion of the energy sector largely explains the dramatic 58\% increase in emissions between 1994 and 2007, and a further massive planned expansion as the engine of economic development means that India's emissions are projected to grow significantly in the future. The Energy and Resources Institute (TERI) in New Delhi has estimated that total commercial energy consumption could increase by a staggering $660 \%$ between 2001 and $2031 .{ }^{81} \mathrm{~A}$ collation of five modelling exercises published by the Ministry of Environment and Forests provides a range of estimates for India's future greenhouse gas emissions trajectory, with projections of per capita emissions in 2031 ranging from 2.77 to $5 \mathrm{tCO}_{2} \mathrm{e}$ and total emissions of 4-7 billion $\mathrm{tCO}_{2} \mathrm{e}$.

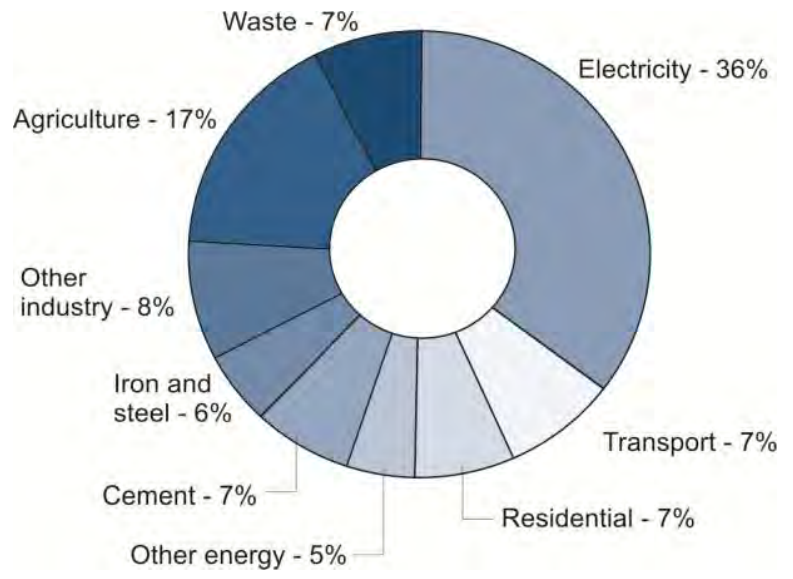

Figure 3.4: Profile of India's greenhouse gas emissions, 2007.

Source: World Resoures Institute, CAIT 8.0.

Note: excludes land use, land use change and forestry which contributes net carbon storage equivalent to $9.3 \%$ of total emissions.

${ }^{81}$ See TERI (2008). 


\section{Domestic climate policy}

The Indian government has already introduced a number of legislative and policy measures that, if successfully implemented, will constrain the rate of growth in greenhouse gas emissions. For the most part, the domestic policy response has been stimulated more by development concerns, particularly energy security and energy access, than by climate change per se. The 2008 National Action Plan on Climate Change (NAPCC) provides an overarching framework under which eight National Missions have ambitious agendas to, for example, improve energy efficiency and boost solar energy production.

Rising concern about the impacts of climate change, which have been evident in growing media coverage since around 2007, has also catalysed a focus on adaptation planning to reduce the country's vulnerability. Several new data gathering initiatives were announced in late 2009, including the establishment of new climate research centres, the launch of satellites to improve data collection and the installation of a new network of weather stations across the South Asia region.

Policy development has thus far been driven from the top down with virtually no initiatives by state governments, although some states have now begun developing climate policies as a response.

\section{The economic context}

Despite an impressive push to expand solar energy, and the fact that India ranks fifth in the world in terms of installed wind capacity, India's energy supply system is highly dependent on fossil fuels. Future growth is also expected to be based predominantly on fossil fuels - particularly coal - for the foreseeable future.

The dominance of small and medium-sized enterprises (SMEs) in India's industry sector also presents a challenge. SMEs - often family-owned firms or cooperatives - account for about two-thirds of Indian industrial and commercial activity, and a large chunk of employment. SMEs are financially and technologically limited as well as heterogeneous, which makes effective regulation of emissions difficult. At the same time, SMEs have sizeable local political clout.

Energy efficiency in large Indian industries already tends to be quite high by world standards, and Indian power tariffs are already among the highest in the world (in terms of purchasing power parity). This leaves 
little room to pursue further emission reductions from industry. Moreover, the energy sector is riddled with subsidies and cross-subsidies, so any climate policies that raise energy prices are likely to add to the costs of the government. An alternative would be a redistribution of the burden by changing pricing and subsidy structures, and a recommendation to this effect came out of an independent commission into fuel pricing led by the former head of the Planning Commission Dr Kirit Parikh in early 2010.

Another challenge is that the majority of Indian livelihoods are supported by small scale agriculture. Like the SME sector, this makes it politically difficult to address the significant contribution to total greenhouse gas emissions that comes from the agricultural sector, since those affected are numerous and poor. Such structural factors, coupled with a sense among Indian policymakers that India is technically and financially limited, create an understandable hesitancy among India's leaders about how much mitigation can be delivered with certainty. This partly explains why the country's ambitious domestic programmes have not been translated into international commitments.

\section{Climate diplomacy}

Prior to 2007 (and in many respects until late 2009) India's approach to the climate negotiations was fairly constant. The core elements of its negotiating stance were clearly visible in its formal submissions to the UNFCCC process, for instance on "Shared Vision". ${ }^{2}$ Vihma has summarised India's stance as based on:

- the principle of common but differentiated responsibilities 83

- reliance on multilateral approaches

- equal per capita entitlements to global natural resources

- overriding priority of the right to development, and

- identifying key vulnerabilities of India to climate change ${ }^{84}$

\footnotetext{
82 See e.g. the summary of key Indian submissions compiled by the World Resources Institute (2009).

83 The principle of common but differentiated responsibilities is enshrined in the 1992 UNFCCC, and reflects an acknowledgement by parties that while both developing and industrialised countries must act together to prevent dangerous climate change, industrialised countries should take the lead in this endeavour.
} 
Despite growing pressure from the industrialised countries, India has repeatedly refused to take on either binding commitments to reduce its overall greenhouse gas emissions or other targets such as "for energy intensity or share of renewables" and rejected "softer forms of international governance, such as standards, sectoral intensity targets or sectoral benchmarking". The issue of technology transfer - mechanisms to provide developing countries with affordable access to modern technologies for reducing greenhouse gas emissions - has long been high on India's list of priority issues to be resolved during negotiations, as is ensuring that any international agreement provides adequate finance to support poor countries in their efforts to adapt to the impacts of climate change.

\section{Explaining continuity}

The fact that India's basic approach to climate diplomacy has held steady for nearly two decades is noteworthy because the country's economy completely changed over the same period and its parliament has been host to a string of different governments (there were six in the 1990s alone). Two factors help to explain this continuity.

The first, noted by a former senior climate negotiator, is that climate diplomacy in India was for a long time shaped by senior bureaucrats, particularly from the environment ministry, in virtual isolation from other foreign policy issues - and hence outside the influence of external political change. ${ }^{85}$ That this pattern was able to persist for so long is partly a reflection of climate issues being a low domestic priority before 2007. Sparse media coverage meant the framing of domestic debate remained relatively stagnant, ${ }^{86}$ and even though media attention has increased over the past three to four years it still focuses very little attention on international negotiations.

The second is the successful institutionalisation of a common normative frame relating to notions of "equity" and to the onus for action being on the industrialised countries. These ideas can be traced as far back as Indira Gandhi's speech to the 1972 UN Conference on the Human Envi-

\footnotetext{
${ }^{84}$ Korppoo et al (2009, p. 48).

85 "India's foreign environmental policy has traditionally been in the hands of a small group of people. The key organisations have been the Ministry of Environment and Forests, and the Ministry of External Affairs, and the leading experts and ideologists in the Indian delegations to multilateral forums have been senior civil servants of these ministries" (Anna Korppoo, et al., 2009, p. 61).

86 Jha (2009).
} 
ronment in Stockholm, in which she proclaimed socio-economic development and the management of environmental issues to be competing priorities, as is noted in Chapter 2 above.

A lack of trust in international institutions in general and the climate negotiations in particular has been an important feature of Indian climate diplomacy since the beginning of the negotiations. ${ }^{87} \mathrm{~A}$ trigger for Indian indignation was the way in which the industrialised countries were seen as framing responsibility for taking action to cut global greenhouse gas emissions and for reshaping the climate agenda in order to protect their own economic interests. ${ }^{8}$

As a response to what have been seen as unfair efforts by rich countries to require India's poor to carry the burden of reducing greenhouse gas emissions, a framing of equity as "equal per capita access to the atmosphere" emerged and has been strongly institutionalised domestically. It has become the dominant norm in public debate, and until recently remained the central pillar on which India's arguments at the UNFCCC rested.

\section{Explaining change}

The first signs of change in India's stance emerged around 2007. At a meeting of the World Economic Forum in Germany, 89 Prime Minister Manmohan Singh announced that India's per capita emissions would never exceed those of the industrialised countries. This pledge was later reiterated in the National Action Plan on Climate Change, and is seen by some as a departure from India's traditional position because for the first time it implied some notional capping of India's greenhouse gas emissions.

In July 2009, India was among the countries at a meeting of the Major Economies Forum (MEF) that together agreed that human-induced climate change should be limited to a global average temperature rise of $2^{\circ} \mathrm{C}$ above pre-industrial levels. ${ }^{90}$ Prior to this, India had been adamant that it would not be bound by any type of limit imposed internationally, and

\footnotetext{
87 See, e.g., Dubash (2009); Jha (2009); Mathur and Varughese (2009); Noronha (2009).

88 See Jha (2009).

${ }^{89}$ World Economic Forum, Gleneagles Dialogue on Climate Change: Third meeting of the Energy and Environment Ministers, Heiligendamm, Berlin, September 2007.

90 See Major Economies Forum (2009).
} 
although the MEF commitment is neither binding nor specific about how the target should be met, it nonetheless suggests a new cooperativeness in the Indian approach.

In the lead-up to COP15 in 2009, the Minister for Environment and Forests, Jairam Ramesh, announced that India would reduce the emissions intensity of its GDP by $20-25 \%$ by 2020 in comparison to the 2005 level. ${ }^{91}$ This was formally restated in early 2010, when India submitted a voluntary pledge to the UNFCCC. ${ }^{92}$ More recently, at COP16 in Cancun, Ramesh's reframing of the sensitive debate around transparency and international monitoring of domestic actions - where he proposed a separate tier of international verification for developing countries, eventually termed International Consultation and Analysis (ICA) - was credited with helping to broker an eventual agreement between the Parties. ${ }^{93}$ That there has been a significant move away from India's historical approach to negotiations is clearly evident from the scale of domestic opposition to the stance promoted by Ramesh since 2009.

\section{Climate diplomacy as foreign policy}

The fact that climate diplomacy has come to be seen by India's political leaders as nested within the broader foreign policy agenda means it is now more significantly influenced by key forces driving foreign policy: the desire for international status, or the pursuit of India's place at "the high table"; regional security; and the protection of national economic interests. Together, these factors motivate a policy course that is in greater alignment with strategically important countries, in particular the United States and China.

There are multiple dimensions to the strategic importance of the United States for India. In security terms, US relationships with other South Asian countries, especially Pakistan, Afghanistan and China, are perceived as sensitive for India. In economic terms, the United States is one of India's major trading partners. With regard to India's ambition to join the high

\footnotetext{
${ }^{91}$ See Dhar (2009).

${ }^{92}$ See Government of India (2010). The pledge to the UNFCCC excluded emissions from the agricultural sector.

93 Interview with a senior European climate negotiator, April 2011.
} 
table internationally, the United States will have a decisive influence over India's attempt to become a permanent member of the UN Security Council. India's relationship with China, sometimes framed as rivalry, is also important in this context. China, a rival for international status, already has a seat on the UN Security Council. From an Indian perspective, China is also a source of unrest in the South Asia region - China and India have an ongoing border conflict, and China has close relations with some of India's "troublesome" neighbours. At the same time, China has become India's major trading partner and is therefore of great economic importance to it. Relations with China are often framed in terms of rivalry inside India, and this dynamic motivates India to "keep pace".

In addition, there is a strong perception in India that the industrialised countries are approaching climate change as an economic issue and trying to use it as a tool to fight competition from the expanding economies of India and elsewhere. There is also an awareness that the competitiveness of Indian industry could be adversely affected if industrialised countries introduced trade measures, such as customs tariffs, directed at major economies that do not take on emissions reduction commitments.

As yet, the new elements of India's stance have not been "institutionalised" domestically within the bureaucracy or parliament. Nor does the new positioning have widespread support among the non-governmental organisation (NGO) community (especially domestic NGOs). In parliament, there has been strong opposition from all parties to the shift in India's stance on climate negotiations. There has also been opposition from within the Indian bureaucracy, especially the Ministry of Environment and Forests.

On the one hand, this makes the shift somewhat fragile, since a change in government - or even a change in minister - might alter the driving logic. On the other hand, the effect of a sense of globalism can be to compel policymakers to make choices "empowering" India towards proactive commitment as opposed to "passivity or paralysis", meaning that it can override the effect of the short term political fluctuations which might otherwise interrupt a policy trajectory.

Industry, meanwhile, has so far played a limited role in shaping climate policy or climate diplomacy. Industry appears to sense no potential threat from India's stance in the negotiations. Where industry is engaged, the focus tends to be on technical aspects related to market mechanisms, most notably the CDM, which is likely to deliver an international revenue 
stream to clean energy projects in India. On these specific issues, industry has had some role in helping to shape the government's contribution to climate negotiations.

It is important to recognise that India has not dispensed with all of the key principles which have been at the core of its traditional stance. Elements of most remain for the time being embedded, at least, in India's negotiating rhetoric. Domestic issues such as equity and poverty alleviation will remain important considerations in Indian policymaking in the near future.

\section{The BASIC dimension}

Aligning itself with a group of countries with per capita emissions that are significantly higher carries some risk for India, not least that it might ultimately be treated in the same way as China by a future international agreement. However, BASIC participation makes sense in the context of India's wider foreign policy goals. BASIC is a club of major international players and regional powers, so membership, like its membership of IBSA and BRIC, aligns well with the drive of India's leaders for greater international status.

BASIC is also a forum for engaging cooperatively with China, and potentially building an improved Sino-Indian relationship. Climate change is one of very few issues on which India and China have good relations, and during a visit to China in 2010, Jairam Ramesh described climate change as a platform for a new Sino-Indian relationship. At the same time, BASIC provides India's leaders with a vehicle through which to work to bring China, in particular, closer to the position in the process of other international parties, including the United States, hopefully building trust and goodwill with the United States.

The G77 remains important to India, not only in strategic terms but also as a basis for its international identity. However, the splintering of different interest groups within the larger G77 forum created a problem for the country's political leaders, who feared India might be left isolated in the negotiations. Ramesh wrote a letter to the Prime Minister in 2009 
suggesting a break from the G77, ${ }^{94}$ which attracted huge criticism when it became public.

The other reason an alliance of this sort is so important to India is the importance of "equity" as a normative driver domestically. Ramesh has been the subject of criticism from certain quarters in India since 2009, accused of "selling out" India's principled position in the climate negotiations. He must thus also been seen to be responding to domestically embedded ideas about what an international agreement should look like. In practice, this means that a notion of equity must be clearly visible in India's stance, and demonstrable by a clear differentiation between industrialised and developing countries. This partly explains India's insistence on a second commitment period for the Kyoto Protocol, as well as Ramesh's introduction of the concept of "equitable access to sustainable development" - aware that the older Indian framing of per capita access to the atmosphere was seen a weak argument by many other Parties.

While there may be few issues in the negotiations on which BASIC can find common ground, they do strongly agree on the principle of common but differentiated responsibilities and on the extension of the Kyoto Protocol. Thus, BASIC is arguably a vehicle through which India can fight for equity while becoming more proactive in the pursuit of an international climate deal.

\subsection{China}

As the world's most populous country, second-largest economy and the largest emitter of greenhouse gases, ${ }^{95}$ China matters a great deal to international efforts to mitigate climate change. The position of China as the biggest exporter and holder of the largest foreign exchange surplus means that decisions made in China - by Chinese institutions and companies will have more bearing on the direction of global efforts to deal with climate change than those in any other country. This, in turn, changes the

\footnotetext{
94 For Indian news coverage on this, see Sethi (2009).

95 See McCurry \& Kollewe, (2011).
} 
nature of China's global responsibilities. While China has an indisputable right to development, the impact of China's trade and outward investments is also indisputable.

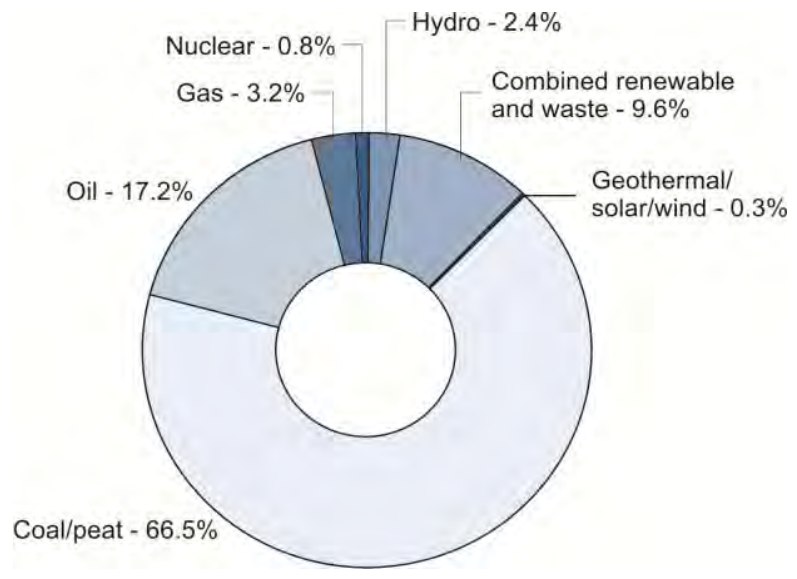

Figure 3.5: China's Energy Mix 2008:

Source: IEA Energy Statistics, 2010, http://www.iea.org/statist/index.htm

Since 2006, when China overtook the United States as the world's largest emitter of greenhouse gases, it has faced increasing pressure to improve its mitigation efforts, make them more transparent, and consider submitting its domestic efforts to an international regime. Climate diplomacy has consequently gained importance on the Chinese foreign policy agenda, and has been embedded in China's overriding goal of presenting itself as a responsible great actor while ensuring that its international commitments do not interfere with domestic development.

Domestically, climate change is predominantly viewed as a development issue. The main trade-offs are gauged in relation to the harm climate change causes development, the cost of action versus inaction, and the opportunities brought about by low-carbon development in terms of clean technology, export competitiveness and innovation. 


\section{Domestic determinants: the energy and climate dilemmas entwined}

China has a history of laudable high-level statements in favour of sustainable development. ${ }^{96}$ However, implementation of rhetorical promises has been difficult, and the blizzard of environmental legislation passed in the 1980s and 1990s did little to curb the rapid increase in polluting activities that came with economic growth. The central government also failed routinely to meet its own environmental targets. As a result, there is widespread scepticism about China's ability to deliver on environmental policy. ${ }^{97}$

Environmental issues were long seen as sectoral and thus outside the scope of key political priorities, but since the mid-2000s climate-related policy has become embedded in the core priorities of central government. The main reason for this is the increasing realisation that energy-, climateand economic-related developments are essentially interlinked, and that political stability and future growth are threatened by energy scarcity and the impacts of environmental degradation.

\section{Energy security driving climate policies}

As the Hu-Wen leadership came to power in the early 2000s, it became obvious that the supercharged growth of the Chinese economy had reached a level at which the energy supply was becoming a serious challenge to China's future development. The ambition to develop China into a harmonious society would simply not be feasible unless considerable new energy sources could be secured and existing sources used far more efficiently. ${ }^{98}$

The numbers speak for themselves. Although China is still the world's fifth-largest oil producer, oil production in its oil fields is peaking even as oil demand continues to increase rapidly. China currently relies on im-

\footnotetext{
${ }^{96}$ In 1994 China was the first country to present a national Agenda 21 (Stockholm Environment Institute \& United Nations Development Programme (China), 2002). Since the ninth five-year programme and the long-term programme for 2010, sustainable development has been a basic policy for and a guiding principle of the country's development (China National Environment Protection Agency, 1998).

97 See OECD (2007).

98 For a more elaborate explanation see Hallding, Han, \& Olsson (2009b).
} 
ports to meet over half its demand, a figure that is projected to rise to $80 \%$ by the late 2020 s. ${ }^{99}$

China is also regarded as richly endowed with coal, but at roughly $13 \%$ of global coal reserves, its stocks are below world average in per capita terms. Recent estimates show that China's coal production could peak as early as the 2020s, and China has in the past five years switched from being a net exporter of coal to an increasingly hungry importer. ${ }^{100}$ The realisation that energy reserves are dwindling, along with having become the world's largest emitter of greenhouse gases, is part of the reason why in 2008 the Scientific Development Concept - which in a nutshell implies dramatically reducing the energy and pollution intensities of socioeconomic development - became a guiding principle of the leadership's development policy. ${ }^{101}$

\section{Increasing concern about climate impacts}

There is also a growing worry at all levels of society about the impacts of climate change on the country's social stability and development prospects. ${ }^{102}$ Climate change impacts are already evident across the country. Severe droughts in the north have led to an acute shortage of water, and failing harvests threaten the livelihood and sustenance of millions of farmers. Southern regions are experiencing severe flooding and, like their northern counterparts, are victims of a reduction in the supply of arable farmland. ${ }^{103}$

Public awareness of environment- and climate-related issues is consequently rising and the general perception of climate change is changing. In a 2008 poll, the environment was ranked the fourth-highest concern in the country, and $10 \%$ ranked it the most important issue. 104

\footnotetext{
${ }^{99}$ See McKinsey \& Company (2009).

100 See, e.g., Alkelett (2010); Lin \& Liu (2009); Rubin (2011).

101 For a more elaborate explanation see Hallding, et al. (2009b).

102 Hallding, et al. (2009a).

103 For English summaries of the National Assessment Report see Y. Ding et al. (2007); E. Lin, Xu, Ju, \& Ma (2007).

104 See Hance (2008).
} 


\section{Green growth and low-carbon opportunities}

There is also a rapidly growing awareness among both business and political leaders that there are considerable low-carbon opportunities for China. Investments in clean technology are not only a strategic move towards innovation-and technology-driven growth, but also a way to come to grips with the interlinked developmental and environmental dilemma the country now faces. 105

The strong momentum behind renewable energy is a clear indication of the political determination to steer development towards a more sustainable path, which in turn has given rise to a political climate that fosters green business opportunities. Since the late 2000s, China has emerged as a world leader in the development of clean energy, and in 2010 China became the world leader in total installed wind capacity - adding 18.9 gigawatts of capacity in that year alone, a $73 \%$ increase - and accounts for more than half the world market for new wind turbines. ${ }^{106}$

Recent research has also demonstrated that a low-carbon development path is feasible, and leading economists have explored the macroeconomic consequences of a low-carbon economy, leading to expectations of positive side-effects such as stabilised growth, job creation and developing competitive advantages. ${ }^{107}$

\section{Climate policy}

China's domestic climate-related policies to date are essentially the positive side-effects of a range of policies implemented to address the country's growing energy security concerns. ${ }^{108}$ The foundation was laid in the eleventh five-year programme (2006-2010), and key policies included a legally binding target to reduce emissions intensity by $20 \%$ by 2010 on 2005 levels, and the Renewable Energy Law, which stipulates an expansion of renewable energy sources in the energy mix from five $\%$ in 2005 to $15 \%$ in 2020 . These two policies became cornerstones of China's National Climate Change Pro-

\footnotetext{
105 See D. Ding, Dai, \& Zhao (2008).

106 See World Wind Energy Association WWEA (2011).

107 See, e.g., Fan et al. (2011).

108 See Hallding, et al. (2009b).
} 
gramme, which was launched in June 2007 - making China the first developing country to publish a national climate change strategy.

Since then, climate change has gradually climbed higher up the list of domestic policy priorities as its own issue. The twelfth five-year programme (2011-2015) has more climatic teeth than previous programmes, including visibly defined emission reduction targets, and for the first time separate targets for energy intensity (a 16\% reduction by 2015) and $\mathrm{CO}_{2}$ emissions per unit of GDP (a 17\% reduction by 2015). These are congruent with the 40 to $45 \%$ reduction in carbon intensity that China announced just before COP15 and reaffirmed at COP16 in Cancun, and are thus evidence of China having internalised its international pledges into its domestic system. ${ }^{109}$

\section{Civil society as a stakeholder in the policy process}

While China's climate policy is largely driven by the central government, expert advice has a clear impact on the top decision makers concerned with the formulation of China's climate policy at both the domestic and the international level. ${ }^{110}$ Influential research institutions include semi-official institutes such as the Chinese Academy of Social Science (CASS) and Qinghua University, one of China's leading institutes for tertiary education. In some cases, these institutes establish science as a guiding principle for policy formulations and at especially important negotiation sessions, such as COP meetings, the division heads of the relevant research institutes join the delegation. ${ }^{111}$

Non-traditional stakeholders such as the media and NGOs are gradually entering the policy implementation arena, occupying a space between the bureaucratic system and civil society. ${ }^{112}$ At times, non-state actors have even assisted the government in environmental protection efforts at the local level, albeit on the condition that they do not criticise the government and accept national policies. ${ }^{113}$ This confirms that there is a con-

\footnotetext{
109 For a good overview see Finamore (2011).

110 See Wübbeke (2010).

111 See Wübbeke (2010), p. 34.

112 See Marks (2010, p. 982).

113 Ibid.
} 
tinual broadening of the range of stakeholders involved in both the domestic and the international climate policy process.

\section{Climate diplomacy}

Since becoming a Party to the UNFCCC in 1994, China has gained a reputation as a recalcitrant actor. For instance, in the high-level segment of COP15, Chinese Premier Wen declined to participate in informal negotiations even though several other Heads of State were present. ${ }^{114}$ This has at times caused extensive frustration with China as a partner. In the final deliberations around the Copenhagen Accord, China's behaviour not only angered its G77 allies, but also caused the Swedish EU presidency and British officials to blame China for the perceived failure of the conference. ${ }^{115}$

These sentiments reflect a general perception - at least in a Northern context - that "China is not interested in reaching a point of common understanding, but only cares about its own national interests", and that when China does engage actively, its motives are primarily economic and never for "the sake of doing something good". 116

The reason that China is perceived as such a difficult player is that its climate diplomacy is influenced not only by domestic perceptions of the issue, but also by an array of foreign policy principles and predetermined codes of conduct - discernible through all areas of its international relations - that do not allow climate change to be tackled as pragmatically as in the domestic context. As a result, there is a strong perception that China's position remains largely unchanged.

\section{What prevents China's stance from changing?}

China's behaviour in international organisations and negotiations is generally guided by three foreign policy principles: first, a concern that international cooperation may lead to dependency and instability; second, a

\footnotetext{
114 For this and other examples see, e.g., Purvis \& Stevenson (2010), p. 11; and Vihma (2010, p. 9)

115 See commentary in the media e.g. in The Guardian by Ed Milliband (2009) and The Economist (China's thing about numbers, 2010). See also Vihma (2010).

116 Interview with a European negotiator (October 2010). This viewpoint came up in more than one interview.
} 
preference for staying out of situations where core economic interests are compromised; and, third, a wish to come across as a responsible player that takes active leadership in the Global South. ${ }^{117}$

In climate diplomacy, this takes the form of China remaining firm on its policy that a climate regime beyond 2012 should involve continued differentiation in responsibilities between developed and developing countries. China also insists on there being no differentiation in mitigation responsibility among developing countries, regardless of the fact that rapidly developing countries such as China and Brazil are much more able to mitigate emissions than poorer countries such as Bangladesh and Cameroon.

China takes this position partly because it is a matter of principle that industrialised countries should remain loyal to their previous commitments, and partly because it finds it unacceptable that expectations of Annex 1 countries should be reduced while countries such as China are committing themselves to voluntary action. This point also explains why China is unlikely to agree to any binding international commitments as long as the domestic inertia on climate legislation in the United States continues.

Given the genuine fear of international regimes as sources of instability and dependence in both China and the United States, a climate deal between the two is likely to be a lowest common denominator agreement in both form and substance. This explains why many observers view the two dominating emitters as playing "hide and seek" in a way that serves each country's domestic interests.

China also resists mandatory emission reductions for itself and other developing countries partly because it is not confident about its ability to achieve a less emission-intensive path for growth. Perhaps the strongest reason is that the political leadership will not engage in international undertakings that they perceive as potentially jeopardising the country's development opportunities. ${ }^{118}$ This explains China's position on technology transfer, which shows that despite the rapid transformation at home,

\footnotetext{
117 For further reading on these principles and how they correlate with climate diplomacy see, e.g., Economy (2001); and Kobayashi (2003). For a fuller elaboration of the principles see Kim (1992); Harding \& Shambaugh (1987); and Zhu (2008).

118 See Brown \& Hsing (2011).
} 
there is still genuine concern that the country lacks sufficient capacity to manage a fast enough transition to a low-carbon development path.

Finally, China's position is heavily influenced by the G77, a majority of the members of which hold that it is of the utmost importance that developed countries move first. And while the G77 is far from unified on all issues, ${ }^{119}$ China takes its leadership role within the group seriously - not least by offering support for many of the smaller countries. Although inconsistent across sessions, China has sometimes compromised its own negotiating position in order to remain consistent with the broader group line. ${ }^{120}$ Consequently, in the practice of foreign policy, while China's emissions profile demands it take a more active and more "responsible" stance in the international negotiations, China's image of itself as a developing country - with matching interests and coherent allies - is not likely to wane any time soon.

\section{Still noteworthy change in some quarters}

There are, however, developments that suggest that China is repositioning itself on some issues, reflected in a stream of government documents including a White Paper on Climate Change Action, published in October 2008, and China's first carbon intensity target, announced in November 2009, which pledges a $40-45 \%$ reduction in carbon intensity from 2005 to 2020. This goal that was formalised in the Cancun Agreements in December 2010 and is further covered by domestic legislation under the twelfth five-year programme (2011 to 2015).

China has also signalled that non-intervention and transparency may no longer be overarching non-negotiables. This indication came at COP16 in Cancun, when a senior member of the Chinese delegation declared that there had been some rethinking on transparency: "Now we think: if we have done something, why not say so?" 121 Having formerly refused international monitoring of domestic mitigation efforts, this statement suggests a loosening of a tightly held position. When China later in the conference agreed to International Consultation and Analysis (ICA) it effectively

\footnotetext{
119 See Vihma (2011a); and Williams (2005).

120 See Kobayashi (2003).

121 See Meng (2010).
} 
agreed to international review of its domestic mitigation efforts. While the implementation schemes have not yet been agreed, this development does signal a change.

The fact that China is signalling willingness to compromise on positions of principle has several explanations. On the one hand, as the Copenhagen pledge has been incorporated into the twelfth five-year programme, the central leadership feels reassured that China will meet its target and thus not risk being exposed as a weak and unreliable actor in the international regime. On the other hand, ICA, unlike Measurement, Reporting and Verification (MRV) of developing countries' own mitigation actions, ensures continued differentiation among developed and developing country Parties and thus does not put China on a par with developed countries in terms of responsibilities.

\section{The BASIC dimension}

There is a debate among leading Chinese foreign policy actors about the nature and direction of China's rise on the world political stage. One strand in that debate holds that as China becomes a major power, it needs to cooperate with other emerging countries such as Brazil, South Africa and India. ${ }^{122}$ This lens is particularly interesting to apply to climate diplomacy.

As the world's largest emitter of greenhouse gases, China is arguably vulnerable in the climate regime, and has a lot to gain from cooperation with its BASIC peers in terms of seeking cover from emission mitigation expectations. Within the BASIC group, China deepens its bonds with three countries that face similar development dilemmas, while sill having the option of using BASIC as a forum to discuss differences amongst themselves. By doing this, the BASIC countries can check positions against each other and perhaps more easily pursue a joint front on issues on which they agree.

While both China and India are traditionally regarded as hardliners and G77 leaders, China is ultimately more exposed to expectations of

\footnotetext{
122 In their policy brief Godement, Duchâtel, \& Moncharmont (2010) make direct reference to Yang Jiemian, head of the Shanghai Institute of International Studies and the brother of China's foreign minister, as one of the proponents of this view.
} 
emission mitigation commitments, not least given its complex and sometimes antagonistic relationship with the United States. BASIC therefore provides China with a platform for both pushing a hard line as a collective rather than an individual, as was seen during COP 15 , and providing cover for China by preventing it from being seen as the only recalcitrant state, which was not particularly successful at COP 15 .

BASIC also fits well into a Chinese foreign policy pattern of using loose groupings to serve different strategic purposes, particularly in "superpower leveraging" against the United States. The USA has the power to engage in most situations without external support, but China still needs alternative strategies to boost its power. ${ }^{123}$ Joining with other countries thus serves an additional purpose in China's transformation into a fully fledged global power.

Since China's opening up in the early 1980s, its foreign policy has rested on Deng Xiaoping's doctrine of: "bide our time and build our capabilities", which implies a strong focus on domestic development and a low profile in international affairs. ${ }^{124}$ Its rapid advance as a global economic power, however, means that China leaves increasingly heavy footprints around the world. By creating constellations of countries for different purposes and under different acronyms, China can continue to bide its time while concurrently using the groupings to support its strategic interests.

\footnotetext{
123 Brazil, South Africa, China, India (BASIC) and the climate change conundrum: Round table discussions, Chatham House, February 2011.

124 Excerpt from a talk between Deng Xianping and Javier Perez de Cuellar, Secretary-General of the United Nations. (China's Foreign Policy, 1982).
} 


\section{BASIC's emergence and wider geopolitical change}

The emergence of BASIC just before COP15 took many by surprise, but reflects an ambition that had been growing among the four countries over the past decade for more effective South-South cooperation on a wide spectrum of international affairs. ${ }^{125}$

To see BASIC as just another G77 subgroup, alongside the Least Developed Countries, the Alliance of Small Island States and others would be to misunderstand the group's nature. Instead, BASIC is a more informal alliance, overlapping with other constellations of emerging powers that focuses on a range of strategic purposes - most consistently growing demands for a stronger say in world politics. BASIC is rooted not only in developing countries' historical efforts to come together to overcome their dependence on the industrialised countries, but also in the specific economic interests and growing power ambitions of Brazil, China, India and South Africa.

The emerging powers have expressed well-articulated ambitions to increase their say in the international system and their share of the global commons. This chapter looks beyond climate negotiations to examine how the BASIC countries engage in other areas of global politics, with the aim of contributing insights that can help lead to constructive results.

\footnotetext{
125 As de la Fontaine \& Seifer (de la Fontaine \& Seifer, 2010) point out "South-South cooperation" is a term that has been used for and associated with all sorts of relations in the Global South. Here we use it do describe cooperation among or led by emerging powers.
} 


\subsection{Reasons for emerging economies to cooperate}

The emerging powers have several reasons for coming together. They want to have a say on global politics, they are gearing up for future economic opportunities and they are keen to maintain their leadership positions in the Global South.

\section{Having a say in global politics}

On the basis of purchasing power, the BASIC countries' share of global GDP doubled from $10.94 \%$ in 1992 to $21.71 \%$ in 2009.126 Their increasing weight in global affairs has led the emerging powers to demand more representation in international organisations.

By the same token, there is an increasing appreciation in the North of the need for global institutions to involve those economies from which a large part of global growth is generated. This is reflected in the invitation to five leading emerging economies - Brazil, China, India, Mexico and South Africa - to join the G8 in the G8+5 Dialogue referred to in Chapter 2, and in the subsequent shift of weight from the G8 to the G20 major economies.

A permanent seat on an enlarged UN Security Council is a top foreign policy objective in Brazil, India and South Africa. The need to reform international financial institutions to better reflect today's financial situation is also bringing emerging economies together in order to realise their demands for greater influence.

These countries have also proved to be a lot more resilient to the financial crisis than the established economies of the North. ${ }^{127}$ Consequently, the emerging economies not only want more of a say in global governance, but can also be expected to demand that role given their increasing importance. ${ }^{128} \mathrm{~A}$ recent example of their shared desire to have a larger say in world affairs is the deliberations around the appointment of a new head

\footnotetext{
126 See Hoch stetler \& Viola (2011).

127 See illustrative chart from The Economist (2010).

128 See Narlikar (2010a).
} 
of the IMF in June 2011, during which the emerging economies all called for a non-European leader.

\section{Gearing up for future economic opportunities}

The emerging economies have a strategic need for a secure supply of resources and access to markets in order to sustain domestic economic development. Spheres of geopolitical interest take on new shapes when the emerging economies seek alternative avenues and relationships to secure their own interests while avoiding conflict with established powers. This is demonstrated in the growth in South-South cooperation in the past decade, but also in increasing competition and tension when conflicting geopolitical interests collide.

In its 2001 BRICs thesis, Goldman Sachs predicted that China and India, respectively, would become dominant global suppliers of manufactured goods and services, while Brazil and Russia would become similarly dominant as suppliers of raw materials. In the first nine years of the millennium, trade between the four BRICs - Brazil, Russia, India and China increased nine times while global trade doubled. ${ }^{129}$ This rapidly growing trade between emerging economies builds on their complementarities in manufacturing and commodities, particularly the strong growth in Chinese manufacturing. ${ }^{130}$

Future growth expectations in emerging economies will continue to push the demand for basic commodities and, as a result, for land. In a world of mounting scarcities it will be increasingly important to secure long-term strategic relations rather than relying on spot markets for the supply of basic commodities. The different constellations of emerging economy cooperation share the trait of building alliances for deepened economic cooperation.

This is not merely a matter of a struggle for resources, however, it is also about competition for future consumer markets. The considerable potential for growth in many parts of the developing world means that the

\footnotetext{
129 Dr. Zhang Yuyang of the CASS quoted in Xinhua interview before April 2010 BRIC meeting in Brasilia at (Xinhua, 2011).

130 See, e.g., Wolf (Wolf, 2011); and Jopson (Jopson, 2010).
} 
pattern of consumption in the North being a global engine for growth is bound to change in favour for strong market development elsewhere.

\section{Maintaining leadership of the Global South}

By cooperating in different constellations, the emerging powers are becoming an intermediate entity of their own - something between the Global North and the Global South. This is particularly obvious in the climate negotiations. ${ }^{131}$ The BASIC countries see it as crucial to remain within, and continue to play leading roles in, the developing world. Strategies to avoid detachment from the developing world community are therefore a factor in the rapidly developing countries coming together, and the BASIC group has repeatedly pledged allegiance to the wider G77 collective.

Over the past half-century the four BASIC countries have individually sometimes in different constellations - acted as representatives for the views of developing nations or taken on roles as ringleaders of groups of developing countries on various global and regional issues. They have been successful in orchestrating pragmatic, joint developing country action and reaction in the UN system, and in rallying support for positions by subscribing to the deep-felt Third World notions of inequity and the need for fairness.

Although determined to continue to play roles as developing country leaders, the BASIC countries face growing concern among many G77 counties about their growing global footprint, increasing dominance and use of power politics.

Continued leadership in the Global South means walking a fine line for the group as well as for the individual BASIC countries. Although the BASIC countries are still defined as developing countries by their per capita income or Human Development Index score, a traditional Third World identity is increasingly ill-fitting given their global ambitions. In climate politics, however, being part of the developing world means maintaining the important distinction between the absolute and binding commitments

131 See Hochstetler \& Viola (2011). 
of the Annex 1 countries and the relative and voluntary commitments of the non-Annex 1 countries.

\subsection{Different constellations of emerging economies}

Given the many reasons for the emerging economies to come together, it is not surprising that the process of relationship building between these countries has been in motion for well over a decade. The ways in which they have coalesced and issues on which they have - or have not - chosen to cooperate reveal patterns that extend far beyond climate change. Three forums in particular shed light on the broader purposes behind the BASIC grouping in climate change negotiations and their internal dynamics:

- The role of the $G 20$ (developing countries) in trade negotiations illustrates that emerging economies have also come together in other UN institutions to block proposals perceived as unfair

- The IBSA Dialogue Forum shows how Brazil, India and South Africa joined forces in a joint call to reform the United Nations, especially the Security Council, to reflect the growing role of developing countries

- The BRIC acronym has developed from a grouping coined by Goldman Sachs to symbolise a shift in global economic power away from the Global North, into a real and increasingly assertive cooperation between Brazil, Russia, India and China, and more recently South Africa

\section{The G20 developing nations in the WTO negotiations}

An early parallel with the emergence of the BASIC cooperation in the climate talks can be found in the negotiations in the World Trade Organization on agricultural trade policy, which took place in Cancun in September 2003. With their history of activism and leading coalitions of developing countries in the General Agreement on Tariffs and Trade (GATT) and the WTO,132 India and Brazil brought together a group of approximately 20

132 See Narlikar (2010b). 
developing nations to lobby against a proposal on agricultural trade jointly put forward by the EU and the United States, which they perceived as unfair and unfavourable to their interests. The group has since been known in trade circles as the G20 developing nations. ${ }^{133}$

There are many similarities between in the way the G20 (developing countries) came together and the narrative around how BASIC emerged in the climate negotiations. Like BASIC at COP15, the launch of the G20 took observers by surprise, in part because it was not apparent what its members had in common given their widely divergent interests on agricultural trade. The then-US Trade Representative, Robert Zoellick, at first even declined to meet the G20 because he believed that it "wouldn't last very long," given the conflicting interests of its leading members - especially Brazil and India. ${ }^{134}$ On the contrary, however, the G20 came to play a crucial role throughout the Doha round before it stalled in July 2008.

In both cases, there was a distinct polarity between developing and developed countries, with a strong feeling among the emerging economies of a lack of fairness in the proposals presented by the industrialised countries, while the developed countries - the United States in particular accused the developing countries of a lack of willingness to compromise.

There is also a tactical parallel between the G20 and BASIC. Both constellations are seen in the North as having taken a reactive and even defensive approach, in which the aim was to prevent a development perceived as unfair and unfavourable to their own interests. In Cancun in 2003 the G20 presented a list of conditions without any room for discussion. Before COP 15, BASIC as a group presented non-negotiables rather than offering solutions on specific topics.

The way in which the Doha round arrived at its current deadlock illustrates the fluidity of trade-offs within the rapidly developing countries between domestic concerns and a willingness to show international lead-

\footnotetext{
133 Separate and distinct from the G20 (major economies), the G20 (developing nations) accounts for $60 \%$ of the world's population, $70 \%$ of its farmers and $26 \%$ of the world's agricultural exports. Membership has fluctuated but currently the following countries are part of the group: Argentina, Bolivia, Brazil, Chile, China, Cuba, Ecuador, Egypt, Guatemala, India, Indonesia, Mexico, Nigeria, Pakistan, Paraguay, Peru, Philippines, South Africa, Tanzania, Thailand, Uruguay, Venezuela and Zimbabwe.

134 See Blustein (2009, p. 137).
} 
ership - tensions that are clearly evident in the climate negotiations. When a final compromise deal was put forward by the WTO Director General, Pascal Lamy, in July 2008 the G20's five-year unity cracked. Brazil supported the compromise but India, backed up by China, blocked the deal on offer. ${ }^{135}$

The Doha story has a final twist, which demonstrates how the current deadlock in US domestic politics limits the prospects for progress in the climate negotiations. According to Blustein, in the end it was not Indian resistance that killed the compromise. Instead, the United States withdrew its support when it became clear to the US Trade Representative that the concessions needed would not pass through the US Congress. ${ }^{136}$

\section{The IBSA Dialogue Forum}

In June 2003 - just two months before the formation of the G20 (developing countries) - the foreign ministers of Brazil, India and South Africa marked the inception of the IBSA Dialogue Forum by calling for reform of the United Nations, particularly the Security Council, to reflect the growing importance of developing countries. ${ }^{137}$ In doing this, they effectively demanded a larger say in world politics for the leading democratic developing economies in South America, Africa and South Asia.

IBSA has since significantly improved relations between India, Brazil and South Africa. The forum has grown to cover a wide array of policy areas, including trade, defence and climate issues, and has developed into a concrete platform for dialogue and exchange between not only government ministries but also non-governmental entities. It also appears that the IBSA countries have a shared vision on a majority of issues at the international level, reflected not least by a $96 \%$ voting convergence in the General Assembly. 138

\footnotetext{
135 Ibid., p. 267. China's role described by Narlikar (2010b).

136 See Blustein (2009, pp. 269-276).

137 The Brasilia Declaration (Brasilia Declaration, 2003) marks the establishment of the IBSA Dialogue Forum. 138 See White (2009).
} 


\section{BRICS}

While IBSA was brought together by a broader notion of global fairness and the need to reform international institutions to reflect the growing power of rapidly developing countries, the BRICS seem to have come together with a more pronounced geopolitical purpose of balancing US hegemony and pushing for a broader, more equitable arrangement for world leadership within which they and others would play a role. ${ }^{139}$

The BRIC acronym was coined by Goldman Sachs in a 2001 paper on the potential of Brazil, Russia, India and China to profoundly alter global economic relationships. O'Neill did not predict organised action by the BRIC countries, but instead used the label as a symbol of the shift in global economic power away from the OECD to the emerging economies.

In 2008, however, Russia used the BRIC label to bring the four countries together in informal meetings, and in June 2009 Russia hosted the first Heads of State summit in Yekaterinburg. ${ }^{140}$ The four have since met in Brazil in April 2010 and in China in April 2011.

In December 2010, South Africa was formally invited by China to join the group, prompting the expansion of the acronym to "BRICS". It is likely that the ties developed in forums such as BASIC contributed to South Africa receiving an invitation at this time. Although a smaller economy, South Africa's "African credentials" are important geopolitically, not least since it gives the BRICS a four-continent breadth of political influence and trade opportunities.

In contrast to IBSA, the BRIC forum has not yet translated into a joint cooperation mechanism. ${ }^{141}$ At the April 2010 BRIC summit in Brasilia, India's Prime Minister, Manmohan Singh, called for closer cooperation in the fields of energy, food security, trade and investment, science and technology, and infrastructure, suggesting an interest in BRICS developing into a forum for practical cooperation. The extent to which this will be possible remains to be seen, given that both China and Russia arguably have significantly different internal dynamics and external visions.

\footnotetext{
${ }^{139}$ See Smith (2011).

140 See Roberts (2010).

141 See Senona (2010).
} 


\subsection{BASIC in the big picture}

BASIC ostensibly deals with climate change, but its raison d'être may well be broader. At the same time, given the fluidity in the global balance of economic power of the past decade, the trade-off calculus of being a BASIC member could change.

\section{What defines emerging power cooperation?}

The BASIC group shares the traits of the G20 (developing nations), IBSA and the BRICS as loosely organised political clubs of emerging powers with vastly different domestic dynamics and diverging, often conflicting, global ambitions. This means the countries could disagree on some climate change issues but still collaborate in the foreseeable future.

The amorphous and partially overlapping nature of these groupings was illustrated in April 2010 when the IBSA and BRIC summits were scheduled back to back. First, the IBSA leaders met and agreed to launch micro-satellites linked to education, agricultural uses and weather monitoring. Then South Africa left and China and Russia joined Brazil and India as BRIC to call for reform of the International Monetary Fund (IMF) and the World Bank. After this, the meeting morphed into BASIC as Russia left, South Africa returned and the discussions turned to climate change. ${ }^{142}$

The events that led to the formation of BASIC provide yet another reference to how the different constellations of emerging power groupings tie in with one another. Most people interviewed for this study think of China as the leader of BASIC. One senior diplomat, however, argues that it was India that played the initiating role before COP15. Although initially lukewarm about India's proposal, China might have changed its mind after pressure from the US President, Barack Obama, during the US-China summit in the second week of November 2009. India then liaised with its Brazilian and South African partners in the IBSA Dialogue Forum. Between the two it was agreed that China would take the lead with India providing support in the background, thereby switching the division of

142 See Bagchi (2010). 
responsibilities from the position in July 2008 when the two countries had jointly opposed a compromise deal to move on the WTO Doha Development Agenda. ${ }^{143}$

Looking back at the nature of emerging power cooperation as it has appeared since the early 2000 s, a set of specific characteristics stands out. At the general level, the fluidity and ad hoc nature in which the cooperation has been organised around specific hot issues is striking. At the same time, there is a convergence around different constellations with the four BASIC countries at the core. The negotiating behaviour of these different groupings has been analysed using a framework developed by Amrita Narlikar (see Table 4.1). According to this framework, four different variables - negotiating strategy, coalitions, framing and leadership - are used to characterise the extent to which the groupings act in a way that challenges or conforms to the norms and values that define the current negotiating system. ${ }^{144}$

Table 4.1 System Challenging versus System Conforming Negotiating Behaviour.

\begin{tabular}{lll}
\hline & System Challenging & System Conforming \\
\hline Negotiating strategy & Distributive & Integrative \\
Coalitions & Blocs & Issue-based \\
Framing & Fairness, equity & Efficiency \\
Leadership & Reluctant at multilateral level, active in & Active at multilateral level \\
& alternative forums & \\
\hline
\end{tabular}

Source: Adapted from Narlikar (2010a, p. 15).

- Negotiating strategy: The G20 developing nations demonstrated largely distributive negotiating behaviour in the WTO negotiations. BASIC displayed a similar pattern before COP15, with firm nonnegotiables and overt threats to walk out of negotiations - knowing this would be very costly to other parties. BASIC strategy post-COP15 has been more integrative. IBSA and the BRICS have demonstrated more integrative behaviour

\footnotetext{
143 Discussion with a senior diplomat from a BASIC country, June 2011.

144 This characterisation of negotiating behaviour has been borrowed from Narlikar (2010b). The analysis, however, is entirely the authors'.
} 
- Coalitions: The way in which the BASIC countries are coming together on a number of different issues indicates bloc behaviour, even though the different forums are markedly issue-oriented

- Framing: There is a strong focus on equity and fairness in each emerging power cooperation. Nonetheless, there are also elements of efficiency in the arguments about representation of the financially strong emerging economies in international institutions such as the IMF. The BASIC group's support for the Copenhagen Accord could also be interpreted as a pragmatic and therefore more efficient solution - at least from a shortterm perspective

- Leadership: There is an ambiguity in the approach to leadership. On certain issues, such as the WTO trade negotiations, the emerging power groupings have been largely reactive. On other issues there have been more proposals, such as the BRICS' idea of an alternative to the US dollar as the global currency. Given the keen interest in populating leading positions in international institutions, there is a clear trend towards interest in multilateral leadership

Some of these elements, such as the focus on non-negotiables, could get in the way of a global climate agreement. However, there are strong indications that BASIC could help bring about convergence on global solutions. For example, the countries' release of "test balloons" in Cancun, such as the Indian concept of equitable access to sustainable development, promoted constructive negotiations. A focus on pragmatic and efficient solutions, such as getting fast-start financing off the ground, is another example. It is unclear, however, to what extent these initiatives are coordinated rather than the actions of individual countries.

\section{The broader geopolitical challenge for BASIC unity}

Although the past decade has seen a rise in the influence and economic prowess of the emerging economies, the real drama on the global stage has been China's growing economic clout and the waning economic supremacy of the United States.

If the long predicted multipolar world is finally becoming a reality, in parallel a new polarity has emerged between China and the United States. The "Washington Consensus" of a post-Cold War neoliberal world 
order is being contested by the concept of a "Beijing Consensus" based on China's growth model, and there is a lively debate about the viability and effectiveness of "Western" versus "Chinese" values to guide future global development. ${ }^{145}$

The current world order lacks the Cold War's neat symmetry in the balance of power across an unambiguous East-West divide. Although dominated by the positions of United States and China, the world is governed by a complex mosaic of geopolitical rivalries, competition for markets and resources, ad hoc alliances and occasional efforts at longer term cooperation.

In this current world order, there are two forces at play that could become defining issues for future cooperation between emerging powers, particularly between China and the other three. First, while China's rise has been one of the drivers of emerging power cooperation, its growing dominance could make it a challenging partner for the other three. Second, the fluidity of international relations provides opportunities for Brazil, India and South Africa to gain influence and maximise benefits through other cooperative forums. Brazil and India in particular have shown signs of playing their cards more carefully between Washington and Beijing, as is illustrated by the following examples of recent developments on trade and the reform of the UN Security Council.

- China's growing dominance in terms of trade and investment is beginning to raise concerns. It is not only North America and Europe that complain about local markets being flooded with low-priced Chinese manufactured goods - similar voices are heard from China's BASIC partners and elsewhere in the developing world. ${ }^{146}$ The warming of Brazilian-US relations since late 2010 was partly caused by common concern about what is seen as an undervalued Chinese currency ${ }^{147}$

- China has not been a strong supporter of its BASIC partners getting permanent seats on the UN Security Council. Following US support in

\footnotetext{
145 See, e.g., Ikenberry (2008); and Ramo (2004). A concrete example of this come from the debate on China's engagements with African countries. For a comprehensive overview, see Bräutigam (2009). 146 See, e.g., Blustein (2009); Leahy (2011b); and Anderlini (2011).

147 See, e.g. Leahy (2011d); and Pearson (2011).
} 
late 2010 for India's Security Council aspirations, President Obama expressed "appreciation" for Brazil's wish to obtain a permanent seat while meeting with Brazilian President Dilma Rousseff in March 2011. ${ }^{148}$ When, at the BRICS meeting later the same month, China expressed "support" for an Indian permanent seat, this could be seen as an indication of successful Indian diplomacy in playing against US and Chinese relations ${ }^{149}$

The extent to which China, perhaps because of its size but also for other reasons, becomes a challenging partner on climate change depends on a number of different factors. Since the BASIC partners have different positions on several of the important negotiating issues there are - at least in theory - potential opportunities for any of the countries to line up with other groups in the climate circus. In this sense, emerging power cooperation is crucial for future unity.

Nonetheless, the role of the United States distinguishes the climate negotiations from many of the other global issues. The deadlock on climate legislation in Washington makes it difficult to identify opportunities for any of the BASIC partners to side with the United States on the climate negotiations. In a joint statement at the end of their third meeting, the BASIC ministers noted that the world could not "wait indefinitely" for US climate legislation, "as it hinders our ability to reach an internationally legally binding agreement". ${ }^{150}$

\footnotetext{
148 See Leahy (2011c).

149 See Bhattacharya (2011).

150 BASIC ministers' joint statement from meeting in Cape Town, 25 April, 2010 (Joint Statement issued at the conclusion of the Third Meeting of BASIC Ministers, 2010).
} 



\section{BASIC and a climate agreement: Disunity or shared vision?}

This chapter examines attempts by Brazil, South Africa, India and China to give substance to their cooperation on climate change, and how BASIC might act as a group to condition and shape a future global climate agreement.

While each of the four has its own priorities within the negotiations, reflecting their diverse domestic contexts described in Chapter 3 , it is also possible to see elements of a shared vision about how a future international climate regime should look. This is important to bring to light, since the support of the BASIC countries for any future climate agreement will most likely hinge on it incorporating the essence of this vision.

\subsection{Cooperation and contention}

\section{Ministerial meetings}

Since COP15 the four countries have met regularly, with each meeting chaired by the host country and attended by their respective environment ministers and sometimes the host country's head of state. ${ }^{151}$ In a handful of these meetings, technical-level workshops on equity, carbon trading and intellectual property rights have run in parallel to the high-level ses-

\footnotetext{
151 Since their first joint press conference in November 2009, the BASIC countries have held regular highlevel ministerial meetings. Their first meeting took place in New Delhi in January 2010, and was followed by meetings the same year in Cape Town in April, Rio de Janeiro in July and Tianjin in October. A sixth ministerial meeting was held in New Delhi in January 2011 and a seventh in South Africa in May 2011.
} 
sions. The issues that have - and have not - been worked on and discussed in these meetings provide some insight into the motives behind cooperation, and raise questions about what kinds of issues they can agree on and what role the group is likely to play as the UNFCCC negotiations move forward.

While the high-level meetings and technical discussions signal a desire for the cooperation to be ongoing, the lack of concrete outcomes so far suggests it has proved difficult to find issues and positions on which to cooperate. Discussions seem to generate agreement on a few broad principles but not settle the finer details needed to translate these into concrete contributions for the international negotiating process. The statement following the Tianjin meeting in October 2010, for instance, calls for a "legally binding outcome", without any mention of what the term "legally binding" entails or which states should be included in what ways in such an agreement. 152

At the same time, there have been no advanced discussions on a range of issues that might have helped to unlock individual elements of the negotiations, such as Measurement, Reporting and Verification (MRV)/ International Consultation and Analysis (ICA), market mechanisms, or long term emission reduction targets and a peak year for global greenhouse gas emissions. ${ }^{153}$ From the outside, it is the issues that are not being discussed that create uncertainty about the breadth of future cooperation and the extent to which the BASIC countries might contribute as a group to move the UNFCCC negotiations forward.

Although the various joint statements issued following each ministerial meeting are generally vague, two clear patterns can be discerned. The first is a consistent call for a second commitment period for the Kyoto Protocol, wherein Annex 1 countries agree to mandatory mitigation commitments for the period following 2012. This has led some observers to note that BASIC

\footnotetext{
152 See fifth Joint Statement of BASIC Ministers (Joint Statement Issues at the Conclusion of the Fifth Meeting of Ministers of BASIC group, 2010).

153 Although there have been attempts to work on carbon budgets, which some BASIC members consider a prerequisite to designing long-term global targets and a peak year.
} 
seems primarily a defensive grouping, the main purpose of which is to avoid mandatory emission reductions for as long as possible. ${ }^{154}$

The second is a clear effort to build bridges with, and show support for, the rest of the G77. BASIC has for instance discussed setting up a funding mechanism to help the poorest and most vulnerable countries, and has repeatedly stated that the fast-start finance pledged in the Copenhagen Accord should be used to assist the poorest developing countries. 155 There have been several developing country observers present at the various BASIC meetings, including incumbent G77 chairs and the chairs of various G77 sub-groupings such as the Africa Group and the Alliance of Small Island States. This perhaps reflects an effort by BASIC to counter possible criticism of it being concerned with an agenda driven by self-interest.

\section{COP meetings: Individual positions versus group agenda}

Some of the developments at COP16 in Cancun brought to the surface the difficulties BASIC is having in defining common ground, and in doing so showed that the quartet is quite willing to disagree in public on particular issues. The four disagreed, for instance, on whether all major greenhouse gas emitters, including the major economies, should be subject to legally binding emission reductions in a future international agreement. South Africa and Brazil indicated an openness to the idea. India for the first time hinted at the possibility of accepting legally binding commitments in "appropriate legal form", although Minister Ramesh later qualified this for his domestic audience by indicating that commitments made by developing countries might not be legally binding. ${ }^{156}$ China, on the other hand, gave no ground and appears least willing to discuss the prospect of mandatory emission reductions for all major emitters.

Their different views on this issue serve as an example of their diverging interests and needs. South Africa's position makes sense in the context

\footnotetext{
${ }^{154}$ A view expressed by many of the developed country respondents to this study.

155 See, e.g., the second, third and fourth Joint Statements of the BASIC Ministers (Joint Statement Issued at the Conclusion of the Fourth Meeting of Ministers of BASIC Group, 2010; Joint Statement Issued at the Conclusion of the Second Meeting of Ministers of BASIC Group, 2010; Joint Statement issued at the conclusion of the Third Meeting of BASIC Ministers, 2010).

156 For Indian, South African and Brazilian statements on this, see TWN Cancun News Update no. 8 and no. 10 (TWN Third World Network, 2011).
} 
of its attempts to bridge North-South differences and is probably also motivated by its role as COP17 host, since in both roles it would be aware of increasing international pressure - not just from industrialised countries - for a legally binding outcome that covers the bulk of global emissions. Brazil's emissions profile is dominated by land use change rather than energy production, which means that emissions reduction obligations for its other BASIC partners would be to Brazil's comparative advantage in economic markets where they compete, particularly in energyintensive trade-exposed sectors. The Indian position was nuanced, according to Jairam Ramesh, to demonstrate that India was not "completely oblivious and insensitive to the views and opinions of a large section of the global community."157 Ramesh highlighted the fact that many developing country partners, including India's neighbours, Bangladesh, the Maldives, Nepal and Bhutan, want a legally binding outcome that includes all major emitters. Accepted at face value, this shows that India continues to place importance on its relationship with the G77 and on the concerns of its regional neighbours, which makes sense looked at through the prism of India's broader foreign policy concern with regional security.

For China, the organising principle for an international agreement should be the right to (belated) economic development rather than a division of responsibility according to the current size of the economy and emissions. Moreover, in the context of the US-China deadlock, the Chinese see little sense in giving too much ground when domestic climate legislation in the United States - something that could step-up US action in the international talks - appears far out of reach. Unlike some of its BASIC partners, China also sees a contradiction in pushing too strongly for the Kyoto Protocol to continue beyond 2012 and simultaneously supporting the prospect of binding emission reduction commitments for major developing countries, since for China the latter implies putting developing and developed countries on a par in terms of mitigation commitments.

\footnotetext{
157 See "Letter from Jairam Ramesh on the Cancun Agreements", 17 December 2010. Available at: (reference as Ramesh, 2010) http://www.sanctuaryasia.com/index.php?view=article\&catid= $122 \% 3$ Aclimate-change\&id=3929\%3Aletter-from-jairam-ramesh-on-the-cancun-agreement\&option= com_content\&Itemid=289.
} 
While this disagreement suggests different visions of what the role and responsibilities of emerging economies should be in a future climate agreement, it also shows that the driving factor behind the BASIC cooperation is more complex than just an attempt to stall progress on mitigation commitments for developing countries.

There were other signs at COP16 of countries pursuing particular agendas unilaterally. India alone - and not BASIC as a group - drove the Shared Vision text on "equitable access to sustainable development". According to a senior Indian official, "It is better that we submit a model before one is thrust on us by the developed countries". ${ }^{158}$ In doing so, however, India showed a willingness to operate outside the BASIC group and to put one or more of its partners in a difficult position. ${ }^{159}$ Meanwhile, South Africa clearly stated a preference for a legally binding outcome to the LCA track or even a single legally binding treaty to replace the two tracks. ${ }^{160}$ There is little evidence that South Africa compromised on this position to preserve BASIC unity, and it has even prompted The Times of India to report that South Africa, at the negotiation session in Tianjin in October 2010, "ruptured BASIC unity" by pushing for a legally binding agreement to be "the pillar of all talks". ${ }^{161}$

These examples illustrate that BASIC is not a tight negotiating bloc. It does not share a common position on all major issues, nor do the partners seem to feel bound in a way that prevents individual manoeuvring. This makes sense in the context of the analysis presented in Chapters 3 and 4, since BASIC is part of a wider arena than just climate policy.

\footnotetext{
158 See article in Economic Times (Goswami, 2010).

159 As told by an interviewee in January 2011, in discussion around the "Shared Vision text", India proposed a text putting 'historical responsibility' to the side and indicated an acceptance of, among other issues, a peak in global emissions "as soon as possible". This put China, which this stage does not accept peak asap, in a difficult position. The compromise outcome is weaker than the original Indian formulation but includes the phrase "equitable access to sustainable development."

160 See, e.g., Earth Negotiations Bulletin, Vol 12, No 492 (Akanle et al., 2010).

161 Times of India (Sethi, 2010).
} 


\subsection{Does BASIC have a shared vision?}

It is perhaps easy to draw the conclusion that BASIC has no real shared vision of how the climate negotiations should unfold, given the diversity of the four countries and their apparent willingness to advance ideas unilaterally inside the UNFCCC process. From this viewpoint, solidarity behind arguments for a second commitment period of the Kyoto Protocol might be seen as primarily a defensive lever, stalling negotiations but offering little clarity on what future progress should look like. However, such a conclusion risks underestimating the desire among BASIC countries for solutions in the negotiating process, and missing the common ground they share around what such a solution should look like.

\section{Differentiated responsibilities as the core principle}

In all their joint statements to mid-2011, there is a repeated emphasis on future negotiations adhering to the Bali Road Map, and by implication its principle of common but differentiated responsibilities. Unlike some Parties, BASIC does not appear to see the Cancun Agreements and the Copenhagen Accord as a move away from the Bali Road Map. At the negotiation session in Bangkok in April 2011, the quartet, along with the wider G77 group and various G77 subgroups, continued to demand clarity on Annex 1 countries' level of commitment to a second period of the Kyoto Protocol before talks could continue. ${ }^{162}$

The Kyoto Protocol has become symbolic of BASIC's vision not because the instrument itself is of key importance but because it tangibly implements the group's interpretation of the principle of differentiated responsibilities. ${ }^{163}$ The wider common but differentiated responsibilities concept is embedded in the Convention, but the notion of differentiation is at present most clearly operationalised by the "firewall" between Annex 1 and

\footnotetext{
162 See, e.g., Earth Negotiations Bulletin, vol 12, no 499. (Cheng, Doran, Schulz, \& Willetts, 2011).

163 The BASIC countries' interpretation of CBDP assumes a clear divide between Annex 1 and non-Annex 1 Parties (especially on mitigation commitments), is not an interpretation accepted by all Parties. Since its first appearance in the IPCC's first Assessment Report, industrialized countries have tended to emphasise "common responsibilities" while developing countries have called for "main responsibility" of developed countries. For a more detailed account of India's position on common but differentiated responsibilities, see Vihma (2011a).
} 
non-Annex 1 Parties in the Protocol. This is the primary place where differentiation with respect to mitigation is enshrined. 164

Why is continued differentiation of paramount importance to the BASIC countries? First, the issue of continued differentiation, in particular through a second commitment period for the Kyoto Protocol, is strongly tied to domestic norms. In countries such as China and India, it is a matter of principle that industrialised countries should deliver on previous commitments. This is particularly important as a trust building process, since the BASIC countries ultimately feel that they will be giving up most by constraining their own basic human development goals by joining an international climate agreement. Second, the four have been eager to demonstrate that they are working towards their own voluntary emission reduction commitments. China, for instance, has included specific reference to $\mathrm{CO}_{2}$ and energy intensity targets in its twelfth five-year programme (2011-2016) that are congruent with its Copenhagen Accord mitigation pledge. Therefore, for the Parties to the UNFCCC to agree a lessening of the obligations of the advanced economies at the same time as major developing countries believe they are taking affirmative domestic action is, from the BASIC perspective, simply unthinkable. Having experienced only a minor share of the industrialisation that has contributed to the current levels of greenhouse gases in the planet's atmosphere, there is a genuine belief among the BASIC countries that responsibility for the problem should be fairly reflected in the onus for action to address the problem.

The hints given by Brazil, South Africa and arguably India at Cancun about being open to major developing countries taking on legally binding commitments in a future agreement, as well as the domestic mitigation programmes initiated in China in particular, indicate a genuine willingness to curb emissions. These signs also signal that the BASIC countries recognise the likelihood of the Kyoto Protocol eventually being supersed-

\footnotetext{
164 The interpretation of common but differentiated responsibilities as a clear divide between Annex 1 and non-Annex 1 Parties - especially on mitigation commitments - is not one accepted by all Parties. Since common but differentiated responsibilities first appeared in the IPCC's first assessment report, industrialised countries have tended to emphasise "common responsibilities" while developing countries have interpreted the "main responsibility" for action as being with developed countries. (For a more detailed account of for instance India's position on common but differentiated responsibilities, and an elaborated version of this argument, see Vihma (2011a).
} 
ed, and are aware of the growing expectation that they play a role in tackling greenhouse gas emissions. However, retaining the Kyoto Protocol is for the time being important because without it the notion of differentiated responsibilities is, from the BASIC perspective, weakened.

That differentiation is the core shared principle of BASIC as a group can be seen in the solution brokered by India at COP16 to break the deadlock over the issue of transparency. Efforts to establish Measurement, Reporting and Verification (MRV) requirements for mitigation actions taken by developing countries of their own accord (i.e. without external support) did not clearly differentiate the obligations between Parties. By contrast, a revised framework for developing countries based on Jairam Ramesh's International Consultation and Analysis proposal does. Tellingly, this compromise position was eventually supported by China, which has long been sensitive about international monitoring of unsupported mitigation action in developing countries.

\subsection{On carbon budgets and equity}

The issue of equity has been high on the BASIC agenda in their ministerial meetings so far. Equity and carbon budgets - that is, how the remaining atmospheric space for continued carbon pollution is to be divided up between countries - were the subject of technical workshops during the Rio de Janeiro and Tianjin meetings in 2010, and equity was discussed again in New Delhi in January 2011. Some reports indicate that the discussions have primarily revolved around the economic implications of various burden-sharing frameworks for the respective countries. ${ }^{165}$

Equity is more than just convenient rhetoric. Discussions around this topic may well represent an attempt by BASIC to operationalise the differentiated responsibility principle. The difficulty for BASIC, as for other Parties, is in finding a shared conceptualisation of equity and a commonly agreed formula for its application.

165 See Vihma (2011b). 
Political leaders in the BASIC countries must certainly be able to show their constituencies that that they have not taken on emission reduction obligations that unfairly constrain future growth prospects. However, the strength of the normative component - the notion of basic fairness and equity - as a fundamental driver for the BASIC countries should not be underestimated. As is described in Chapters 2 and 3, the normative influence of equity for these four countries (and for most of the developing world) goes back further and runs wider than the climate change negotiations. However, two factors have inadvertently brought equity concerns to the top of BASIC's joint climate agenda. The first was the "2 degrees" global warming target adopted by the Major Economies Forum (MEF) and later the Copenhagen Accord in 2009. The second was the long term emission reduction proposals tabled by industrialised countries at COP15. At the time, China and the other BASIC countries rejected a top-down pledge by industrialised countries to reduce their emissions by $80 \%$ by 2050 as part of a global target $50 \%$ reduction. ${ }^{166}$

\section{Dividing the carbon budget}

It is necessary to look closely at the issue of carbon budgets in order to fully understand why the BASIC countries rejected what seems, on the surface, to be a positive step towards ambitious global mitigation. As is illustrated by Figure 5.1, the 2050 targets put forward by the industrialised countries at COP15 imply a tight squeeze on the remaining carbon space available to developing countries when seen from a per capita emissions perspective. What appears to allow for a substantial increase in absolute developing country emissions before a peak in 2030 translates to a reduction in already-low per capita emissions from around 2020. These targets effectively imply reduced development opportunities for much of the developing world, unless an unprecedented transfer of finance and technology were to be catalysed to support these countries moving rapidly to an ultra-low carbon development path.

166 See, e.g., Rapp et al. (2010). 

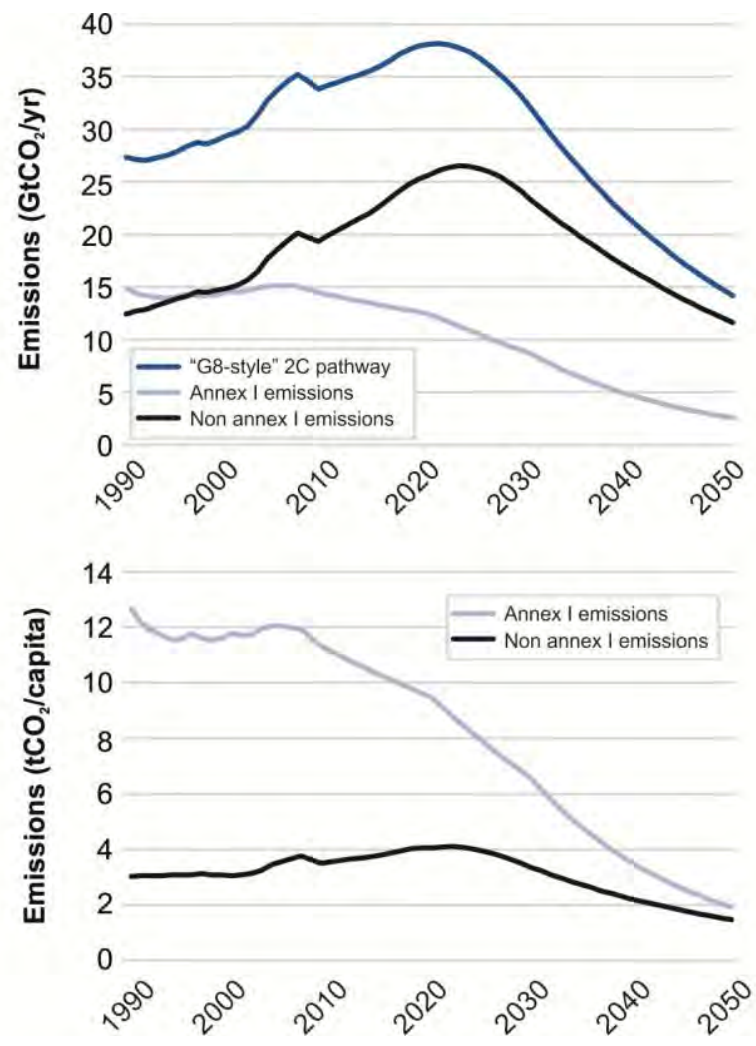

Figure 5.1: The consequences for the developing world of a global emission reduction target of $50 \%$ by 2050 combined with a target of $80 \%$ reductions by Annex 1 countries over the same period.

Source: Developed by Sivan Kartha, Stockholm Environment Institute.

Although united in dismissing the implied carbon budget at Copenhagen, it has become clear from the BASIC workshops in 2010 that the four countries have diverging views on what equity means and how it should be operationalised within the negotiations. The group's difficulty in finding a shared vision on equity is evident in the statement from the Tianjin meeting in October 2010, which was short and repetitive compared to earlier statements. ${ }^{167}$

\footnotetext{
167 See Fifth Joint statement of BASIC Ministers, (Joint Statement Issues at the Conclusion of the Fifth Meeting of Ministers of BASIC group, 2010) which makes brief reference to the concept of "equitable
} 
This has a lot to do with the different domestic contexts facing each country. India's per capita emissions are much lower than the other three and India ranks lowest of the four in human development terms. Equity has thus been framed with a strong emphasis on the per capita angle and the concept of "capacity to pay", as well as the principle of historical responsibility. Brazil and China have higher per capita emissions - although still below most industrialised countries, particularly in the case of China which is a reflection of recent rapid economic growth, and instead emphasise historical responsibility for emissions as the key underlying principle. South Africa favours a multi-criteria approach including not only historical responsibility but also capacity and level of human development, reflecting its relatively high per capita emissions but low development status in world terms (it is ranked far below both Brazil and China in this regard).

\subsection{What does this imply for BASIC's future?}

Any future agreement must appeal to BASIC's common sense of differentiated responsibility. This does not imply no action by major emerging economies, but rather a clear difference in responsibilities between industrialised and other countries. Transparency is achieved through the distinction between MRV and ICA. Emissions reduction obligations are for the time being ensured by continuation of the Kyoto Protocol. If and when the Protocol is superseded by a single global agreement, the concept of differentiation must still be visible.

Any proposals on future global emission targets and peak years have implications for the "development space" of the BASIC countries and the developing world more broadly. This needs to be taken into account by the industrialised countries if BASIC support is to be forthcoming.

Equity matters. While equity has been labelled a "non-starter" by some developed country negotiators, ${ }^{168}$ the importance that BASIC and other developing countries attach to the concept must be taken seriously in order to facilitate constructive dialogue.

access to sustainable development" and notes that future equity discussions will also include equity dimensions of adaptation. Compare this to fourth joint statement which is more concrete on equity, noting the specific need to understand, "the economic, social, scientific and technical implications of equitable access to carbon space."

168 Interview with a senior developed country negotiator, October 2011. 



\section{Trends and developments: Where is BASIC heading?}

The central questions about the future of BASIC are whether it will stay together and, if so, the role it will play. Needless to say, there are no clear answers to these questions. Yet, the research behind this report points to a handful of important trends and developments, which, taken together, indicate a few possible scenarios for the BASIC story to evolve.

\section{In a league of their own}

The BASIC countries are increasingly no longer viewed as developing countries with an indisputable right to prioritise economic development over all other issues. Due particularly to the size of their current and future emissions, they are expected - by both the industrialised countries and the more climate vulnerable poorer developing countries - to play a larger role in international efforts to mitigate the effects of and adapt to climate change. The pressure from these expectations has led them to seek collaborative efforts within the climate regime.

By coming together in a separate group, the four countries are distinguishing themselves from both industrialised and poorer developing countries. The way in which they have been positioning themselves reflects the fluidity of their position, rather than a fixed obstructionist position, between developing and developed countries.

\section{Still developing countries at heart}

Despite their rapid development paths, BASIC still provides important leverage for developing countries in relation to the industrialised countries. This has changed the negotiating playing field, where it is clearer than ever that a single set of norms no longer dominates. Instead, different values and different priorities create constellations and loyalty groups 
across the North-South divide, leading to outcomes that were perhaps unthinkable only a few years ago.

Due primarily to their rapidly rising emissions and growing economies - and the expectations of further action that come with this - it is vital for the BASIC countries to remain an integral part of the developing world collective. This can be seen in their work on equity and the issue of how the remaining carbon budget should be divided. BASIC's attempt to find a common position signals it still sees equity as a crucial building block of any post-2012 climate agreement.

\section{Broad geopolitical value rather than a climate negotiation block}

Cooperation between the BASIC countries in the climate negotiations to date does not paint a picture of a tight negotiation block. The pattern that emerges is one of sporadic cooperation on an ad hoc basis that can meet strategic objectives that overlap with already determined goals.

This behaviour is reflected in how these emerging powers collaborate on other geopolitical issues. The amorphous nature of the various constellations of emerging power cooperation suggests a strategic value that extends far beyond the scope of the climate negotiations, and is more about positioning in world politics.

If one accepts that broader positioning is the main rationale for cooperation, this means that finding common ground on specific issues in the climate talks is not essential to cooperation. Instead, the BASIC group focuses on a few bottom line issues, where they can find common ground that is in line with the wish to be perceived as responsible stakeholders, the need to defend their own strategic interests and the need to promote broader developing world positions.

\section{Different members playing different roles}

The general view expressed by most people interviewed for this study is that China played the role as leader and initiator of the BASIC cooperation. Yet, as is mentioned in this report, it may well be that India, rather than China, acted as BASIC architect. This perception also fits the picture that has evolved since COP15, in which India has been seen to be playing an 
active and constructive role, for example, in brokering an agreement at COP16 in Cancun on International Consultation and Analysis.

While BASIC clearly hinges on the role it plays in Chinese-Indian relations, all four see utility in the cooperation. For India, Brazil and South Africa, the BASIC forum plays to a common foreign policy objective of raising the international status of each. Climate diplomacy can thus be seen as part of a wider set of geopolitical manoeuvrings that unlock specific climate sticking points in exchange for achieving wider diplomatic goals.

Although South Africa and Brazil have been seen to play less central roles within BASIC, South Africa's hosting of COP17 in December 2011 and Brazil's role as convener of United Nations Conference on Sustainable Development, or Rio+20, in June 2012 put these two countries centre stage. Both are clearly interested in hosting successful events, and there is an obvious role for BASIC to play at these important meetings.

\section{Significant international pledges - ambitious domestic policies}

While the BASIC countries are widely seen as reactive in the international climate negotiations, recent research shows that in terms of deviation from plausible reference business-as-usual estimates, their Copenhagen Accord pledges are all at least as ambitious as, and generally considerably more ambitious than, developed country pledges. ${ }^{169}$

Nonetheless, there are significant differences between these pledges and the scale of action initiated domestically. Ambitious domestic polices to promote development, energy security and environmental quality have helped establish dynamic clean-tech sectors, particularly in China, Brazil and India. A forthcoming report ranks these three first, fifth and tenth, respectively, in a global evaluation of value added from clean energy technology. ${ }^{170}$ This is significant, not least because it indicates a growing role for the BASIC countries in competition for clean technology markets.

\footnotetext{
169 See Kartha \& Erickson (2011).

170 See presentation from Cleantech Forum, Amsterdam May 9, 2011 (WWF, 2011). Full data will be presented in a new version of the WWF Clean Economy, Living Plan et report to be published in the autumn 2011.
} 


\section{Here to stay: Three scenarios for the future of BASIC}

This report concludes that BASIC will remain a force in the climate negotiations for the foreseeable future. However, while the BASIC countries are currently partners in climate diplomacy and elsewhere, they are also competitors in the quest for global markets and international status. Both the partnership and the competitive aspects of this dynamic give extra vitality to the BASIC forum as a venue for both cooperation and keeping an eye on one another.

Consequently, the BASIC narrative could develop along different trajectories, reflecting the priorities of the four BASIC countries as well as the dynamics between them. The scenarios sketched below illustrate three different directions of future BASIC cooperation. These should be seen as complementary to one another as the BASIC cooperation in reality contains elements of all three.

\section{Fading away after having served its purpose in Copenhagen}

As this report shows, it was the mounting pressures before COP15 that brought the four emerging economies together in the BASIC group. The level of ambition in terms the joint strategy coordination that the BASIC group performed during the Copenhagen conference has not been seen since. It is possible, therefore, that the BASIC cooperation served its purpose during COP15 and that it will play a diminishing role in the future.

The individual BASIC countries could start to act more independently or in various other constellations to secure their own, sometimes conflicting, interests. The active Indian diplomacy during COP16 in Cancun, and the special roles of South Africa and Brazil in relation to COP17 and Rio+20 are possible examples of this.

\section{A forum for constructive dialogue}

The emergence of the BASIC group before COP15 came across as reactive. Yet, without the BASIC countries' active participation, the Copenhagen Accord would never have seen the light of day.

The spirit and work of the BASIC group since COP15 indicate a growing interest in using BASIC as a forum to elaborate alternative solutions. Areas in which the BASIC group could come to play an active and constructive role include elaboration of equity-related issues, such as the new term 
"equitable access to sustainable development" that was suggested by Jairam Ramesh in Cancun.

A continued commitment to the BASIC group from all four countries does also have the power to unleash positive BASIC dynamics that stimulate the group to engage in constructive compromise. Could BASIC help to unlock the US-China deadlock? India could come to play a key role in this regard, given the strategic importance of both countries to Indian foreign policy objectives and the substantial improvements in recent years in the US-India relationship.

If the BASIC narrative were to develop along this scenario, it is possible that other emerging economies could join the group in what the group terms the "BASIC-plus" approach.

\section{Firewall protection}

A third possible scenario is that BASIC continues mostly as a reactive grouping to provide firewall protection in case the group members come under joint pressure once again. The fact that BASIC ministers in charge of climate issues have been meeting on a quarterly basis proves that the group regards it as valuable to keep the cooperation alive.

That BASIC ministers continue to meet also sends a strong signal to the rest of the world about the determination of the group to stay together. Although we have not yet seen any particularly strong statements from the group, the cooperation can always be brought up to speed on a needs basis.

\section{Engaging with BASIC - as a group or as individual entities}

Although they often work together, the BASIC countries remain four separate entities that operate in diverse material and ideological contexts with their own particular policy priorities and strategies. This leads them to be partners on some issues, but not on others. A better understanding of what these issues are - and how they fit with the countries' individual perspectives - could lead to more successful negotiations.

The BASIC countries' positions within climate negotiations must be understood in their broader geopolitical context. Domestically, each country must navigate a trio of challenges: first, continued internal improvements in well-being, including economic development, and social and political stability; second, a more appropriate positioning in the interna- 
tional order, with influence and status commensurate with their size and global importance; and, third, the current and future disruptive consequences of climate change. These challenges tend to vary in importance based on the proximity (in time) of threats and opportunities. Where they are similar across the countries, cooperation is likely to be facilitated. Where they diverge, we might expect greater challenges to cooperation between the BASIC countries.

As the BASIC countries play increasingly larger roles in climate negotiations and in international politics overall, understanding the motives that drive them could help others engage with them more effectively. 


\section{Sammanfattning}

Givet omfattningen av deras ekonomiska och geopolitiska inflytande är BASIC länderna - både individuellt och kollektivt - snabbt på väg mot den internationella politikens epicentrum. Deras ökade inflytande i de internationella klimatförhandlingarna blev för första gången extra tydlig under klimatmötet i Köpenhamn i december 2009 (COP15). De fyra länderna tycktes då ha en gemensam strategi, och spelade tillsammans med USA en nyckelroll i förhandlingarna om konferensens slutgiltiga politiska resultat - Köpenhamnsavtalet.

BASIC-gruppens framväxt innan COP15 bör ses som en reaktion på yttre påtryckningar på dessa länder att spela en större roll, eller ta mer ansvar, inom den globala klimatpolitiken. Ländernas ökande roll i världspolitiken och ekonomin, samt det faktum att de alla haft snabbt ökande koldioxidutsläpp de senaste åren, har genererat starka påtryckningar på BASIC-länderna att åta sig obligatoriska minskningar av sina växthusgasutsläpp internationellt. Två tydliga exempel på den strategi som industrialiserade länder använt för att öka påtryckningar och uppmuntra till globalt ansvarstagande är att bjuda in BASIC-länderna till samtal om energioch klimatfrågor i Major Economies Forum (som samlar världen sjutton största utsläppare) och G8 plus 5 dialogen om klimat och energi (som samlar världens tretton största utsläppare).

Bakgrunden till BASIC-samarbetet kan även spåras tillbaka till en gemensam "tredje världen"-identitet som har formats under flera decennier i G77-gruppen där alla fyra har varit väldigt inflytelserika. Utöver detta har BASIC-länderna samarbetat i olika konstellationer utanför klimatförhandlingarna sedan börjar av 2000-talet. Till exempel så har Indien, Brasilien och Sydafrika skapat IBSA Dialogue Form, en grupp som genom olika kollektiva ansatser i stort syftar till driva igenom en reformering av FN:s säkerhetsråd. På samma sätt har Brasilien, Ryssland, Indien, Kina och Sydafrika skapat BRICS, ett samarbetsorgan främst inom det ekonomiska området där målet är att motverka USA:s dominans i världsekonomin. Så medan BASIC-gruppen skenbart handlar om klimatförhandlingarna, finns 
det mycket som tyder på att drivkrafterna bakom samarbetet bredare, vilket indirekt innebär att behovet av att utveckla en gemensam klimatplattform blir mindre akut.

Även om dessa fyra länder ibland arbetar inom vissa politiska områden är det viktigt att inse att BASIC-gruppen består av fyra separata individer med egna politiska prioriteringar och strategier. Eftersom de olika idémässiga, materiella och relationella problem som varje land tar till förhandlingsbordet utgör den grund som BASIC samarbetet byggs på blir de partners $\mathrm{i}$ vissa frågor men inte andra. Ett tydligt exempel på detta sågs under COP16 $\mathrm{i}$ Cancun när Indien sökte samarbete utanför BASIC-gruppen för att få in frasen "equitable access to sustainable development" i förhandlingstexten.

En sak som BASIC-länderna har gemensamt är att de alla åtagit sig nationella utsläppsminskningar i enlighet med Köpgenhamnsavtalet som dessutom utgör betydande steg från business-as-usual-projektioner. Framförallt i Brasilien och Kina så stöds dessa löften av nationellt obligatoriska mål och en bredare politik för att främja utveckling, energisäkerhet och miljömässiga kvalitetsstandarder.

Sedan COP15 i december 2009 så har ministrar från BASIC-länderna med ansvar för klimatfrågor träffats regelbundet varje kvartal, något som tyder på att gruppen är inriktad på att samarbetet skall fortsätta. Från de gemensamma uttalanden som publicerats efter varje möte har två saker upprepats i varje uttalande, något som ger viss indikation på hur länderna positionerar sig i sitt samarbete. Dels uppmanar de till en andra åtagandeperiod för Kyotoprotokollet, och dels anstränger de sig för att främja sina relationer med resten av G77-gruppen, bland annat genom krav på ökad klimatfinansiering. Ministermötena verkar således främst ha genererat enighet kring ett fåtal breda principer, men har hittills inte kunnat lösa frågor på detaljnivå, vilket också gjort det svårt att komma med ett gemensamt, konkret bidrag till den internationella förhandlingsprocessen.

En fråga där BASIC-länderna försökt att nå en gemensam ståndpunkt berör rättvis bördefördelning, och framförallt hur den kvarvarande koldioxidbudgeten skall delas proportionellt mellan länder. En handfull tekniska workshops på ämnet har genomförts parallellt med högnivåmötena, men hittills har inga tecken på att konsensus nåtts kommit upp till ytan. En av de främsta anledningarna till att en gemensam syn hittills uteblivit är att BASIC-länderna ser väldigt olika på den här frågan: medan Indien förespråkar en per capita-uppdelning föredrar Brasilien och Kina att stor 
hänsyn tas till länders historiska utsläpp och Sydafrika en blandning av dessa två som också ta hänsyn till länders relativa kapacitet. Då dessa synsätt framförallt är grundade i deras respektive inrikespolitiska verklighet - och inte den likvärdiga internationella positionering - är det inte orimligt att anta att en gemensam ståndpunkt är mycket svår att få fram.

Den brist på samsyn i detaljfrågor som vi hittills sett har lett vissa till att hävda att BASIC-länderna till syvende och sist är en blockerande grupp som endast kan komma överens om att de vill undvika bindande internationella åtaganden om utsläppsminskningar så länge som möjligt. Även om detta är en del av deras gemensamma agenda missar en sådan argumentation det faktum att det är mycket utmanande för fyra stater så olika som BASIC-länderna att enas om en gemensam plattform. Man missar även att klimatförhandlingarna är tätt relaterade till andra politiska områden som ekonomi och handel som inte bara måste hanteras parallellt men som också indirekt motverkar en överenskommelse.

Det finns dock tecken på att vissa BASIC-länder ensidigt bidrar till att föra den globala klimatprocessen framåt. Indien spelade vid COP16 i Cancun en nyckelroll i slutskedet av förhandlingarna genom att förespråka det behovsbaserade konceptet "equitable access to sustainable development", och blev vitt och brett beskriven som att ha spelat en konstruktiv roll. Det finns dock föga bevis för att denna medlingsinsats var ett gemensamt drag från BASIC-gruppen, vilket vittnar om att samarbetet $-i$ alla fall för stunden - är ett där individuella BASIC-länder är mer benägna att få till stånd lösningar än gruppen som kollektiv.

Mot denna bakgrund kan BASIC-gruppen visa sig ha varit en tillfällig konstellation som tjänade ett visst syfte vid ett mycket viktigt skede i den internationella klimatpolitiken. Inom gruppen kan i synnerhet Kinas växande dominans göra landet till en svår fortsatt samarbetspartner. Det kan också vara så att BASIC-länderna väljer att fortsätta maximera bredare diplomatiska och geopolitiska fördelar genom relationer utanför gruppen. Oavsett vilken riktning deras gemensamma framtid tar kommer BASICländerna att fortsätta ta större och större plats i världspolitiken, både innanför och utanför klimatförhandlingarna. 



\section{Appendix A: Methods and conceptual framework}

Our analysis draws on a neo-institutionalist conceptual framework that emphasizes the complex interrelationships within social systems. ${ }^{171}$ In the actor-structure dichotomy common within the social sciences, it is not only nation-states that are the important and influential actors driving of policy development, but also organized groups such as large commercial enterprises and associations, NGOs, and coalitions of diverse groups.

The social structures that facilitate and constrain actor choices are conceptualized in terms of four core dimensions considered particularly important to social science approaches to policy-making processes. These dimensions can be summarised in terms of four main factors:

1) Institutional arrangements that govern policymaking, the economy and other relevant areas of social life ${ }^{172}$. Institutions constitute the rulesof-the-game for governance, including the distribution of policy authority between different centres of political power (different levels and branches of government, quasi-governmental bodies), and other factors that influence the economic and social costs of policy change

2) Cultural factors, as expressed in the way issues such as climate change and its remedies are understood, framed, and prioritized in relation to other policy goals in a particular national context ${ }^{173}$

\footnotetext{
171 See, e.g., Burns \& Flam (1987); and Carson \& Román (2010).

172 Ibid.

${ }^{173}$ Hall (1993); Sabatier \& Jenkins-Smith (1993); and Benford \& Snow (2000).
} 
3) Relational factors, in the form of alignments and constellations of actors that exert meaningful influence over policy. ${ }^{174}$ These three dimensions constitute a highly dynamic mix that varies from one country to another, and from one setting to another

4) The fourth dimension is the multi-level arena in which policymaking on issues like climate change takes place, ranging from global to national to regional and local ${ }^{175}$

Policy developments at these different levels interact with one another in important ways, as became clear from Obama's efforts at "shuttle diplomacy" between China, the US Congress, and other important actors in the preparations for Copenhagen. Multi-level interactions are also apparent in cases such as Brazil, in which local/regional developments profoundly influence national policy positions.

An additional factor, though not social in nature, is the natural resource base, particularly in the form of energy resources. Social and political power is linked to access or control over this natural resource base (i.e., coal, oil, water, etc.). Although it is not a social factor per se, path dependencies tied to particular energy sources may be strongly reinforced by the interests of groups whose future prosperity is linked to those sources. ${ }^{176}$ Actors pursue their ideal and material goals in the complex environment of obstacle and opportunity created by these various forms of structure. One goal of this report has been to map out its contours in the countries that make up BASIC.

\footnotetext{
174 See, e.g., Knoke, Pappi, Broadbent, \& Tsujinake, (1996).

175 See, e.g., Hooghe \& Marks (2001).

176 See Carson \& Román (2010).
} 


\section{References}

Adil Najam. (2004). Dynamics of the Southern Collective: Developing Countries in Desertification Negotiations. Global Environmental Politics, 4, 128-154.

Akanle, T., Appleton, A., Kulovesi, K., McColl, V., Recio, E., Schulz, A., \& Sommerville, M. (2010, Dec 4). CANCUN HIGHLIGHTS. Earth Negotiations Bulletin Volume 12 Number 492. Retrieved Jan 22, 2011, from http://www.iisd.ca/vol12/ enb12492e.html

Aleklett, K. (2010, April 3). Peak Coal in China. Retrieved from http://www. energybulletin.net/stories/2010-11-17/peak-coal-china

Anderlini, J. (2011, Apr 14). China cements role as top of the Brics. FT.com Retrieved Apr 16, 2011, from http://www.ft.com/cms/s/0/da3b25ec-66b711e0-8d88-00144feab49a.html\#ixzz1QkHgYr00

Bagchi, I. (2010). PM against merger of IBSA, BRIC blocs. The Times of India Retrieved Feb 22, 2011, from http://articles.timesofindia.indiatimes.com/201004-17/india/28133294_1_bric-countries-ibsa-populations-and-diverse-societies

Bhattacharya, A. K. (2011). China, Russia endorse India's place in un Security Council. Business Standard Retrieved Apr 22, 2011.

Benford, R. D., \& Snow, D. A. (2000). Framing Processes and Social Movements: An Overview and Assessment. Annual Review of Sociology, 26, 611-639.

Blustein, P. (2009). Misadventures of the most favored nations : clashing egos, inflated ambitions, and the great shambles of the world trade system (1st ed.). New York: PublicAffairs.

Brasilia Declaration. (2003) Retrieved April 13, 2011, from http://www.itamaraty.gov.br/temas-mais-informacoes/temas-maisinformacoes/saiba-mais-ibas/documentos-emitidos-pelos-chefes-de-estado-ede/brasilia-declaration/view

Bräutigam, D. (2009). The Dragon's Gift: The Real Story of China in Africa. Oxford: Oxford University Press.

Braveboy-Wagner, J. A. (2009). Institutions of the Global South. New York: Routledge.

Brown, K., \& Hsing, L. S. (2011). Trying to Read the New "Assertive" China Right Asia Programme Paper (pp. 1-17). London: Chatham House.

Burns, T. R., \& Flam, H. (Eds.). (1987). The Shaping of Social Organization: Social Rule System Theory with Applications. London, England: Sage Publications Ltd.

Carlson, A. (2011). Moving Beyond Sovereignty? A brief consideration of recent changes in China's approach to international order and the emergence of the tianxia concept. [Article]. Journal of Contemporary China, 20(68), 89-102. doi: 10.1080/10670564.2011.520848. 
Carson, M., \& Román, M. (2010). Tipping Point: Crossroads for US Climate Policy. In C. Lever-Tracy (Ed.), Routledge International Handbook of Climate Change and Society. London: Routledge.

Cheng, Q., Doran, P., Schulz, A., \& Willetts, L. (2011, 11 Apr). Summary of the Bangkok Climate Talks. Earth Negotiations Bulletin vol 12, no 499. Retrieved Apr 22, 2011, from http://www.iisd.ca/download/pdf/enb12499e.pdf

China National Environment Protection Agency. (1998). China's National Report on Implementation of the Convention on Biological Diversity Retrieved April 22, 2011, from http://bpsp-neca.brim.ac.cn/books/ntlrpt/chapter22.1. html\#China\%20National\%20Ninth\%20Five-year\%20Plan\%20for\%20 Economic\%20and\%20Social\%20Development\%20and\%20Longterm\%20Program $\% 20$ for $\% 202010$

China's Foreign Policy. (1982). Selected Works of Deng Xiaoping, Volume II (19751982) Retrieved April 29, 2011, from http://english.peopledaily.com.cn/dengxp/ vol2/text/b1600.html

China's thing about numbers. (2010). Economist, 394(8663), 2p.

Clayton, J. (2008, Jan 26). Energy Crisis Closes South African Mines, The Times. Retrieved from http://business.timesonline.co.uk/tol/business/ industry_sectors/natural_resources/article3254147.ece

Creamer, T. (2011, 8 Feb). Draft carbon tax a "nonstarter", Nyembezi-Heita asserts. Engineering News Retrieved Mar 12, 2011, from http://www.engineeringnews. co.za/article/draft-carbon-tax-a-nonstarter-nyembezi-heita-asserts-2011-02-08

Dasgupta, S. (2009). Copenhagen conference: India, China plan joint exit. The Times of India Retrieved April 9, 2011, from http://articles.timesofindia. indiatimes.com/2009-11-28/india/28074806_1_rich-nations-india-and-chinacopenhagen-conference

de la Fontaine, D., \& Seifer, J. (2010). The Role of South-South Cooperation in Present Brazilian Foreign Policy: Actors, Interests and Functions (Article). Retrieved May 8, from Institute of Latin America Studies, Stockholm University http://www.lai.su.se/gallery/bilagor/STCHLM_PAPERS_LatAm_2010_dana\%20e t\%20al.pdf

Devraj, R. (2009). India-China nudge forward on climate issues, Asia Times Online.

Dhar, A. (2009). Jairam Ramesh: 20-25 \% carbon emission intensity cut by 2020, The Hindu. Retrieved from http://www.hindu.com/2009/12/04/stories/ 2009120456550100.htm

Ding, D., Dai, D., \& Zhao, M. (2008). Development of a low-carbon economy in China. [Article]. International Journal for Sustainable Development \& World Ecology, 15(4), 6. doi: 10.3843/SusDev.15.4:7.

Ding, Y., Ren, G., Shi, G., Gong, P., Zheng, X., Zhai, P., Dai, X. (2007). China's National Assessment Report on Climate Change (I): Climate change in China and the future trend. Advances in Climate Change Research, 2007(3), 1-5.

Dubash, N. K. (2009). Toward a Progressive Indian and Global Climate Politics Centre for Policy Research Climate Initiative, Working Paper (Vol. 2009/1 (September)). New Delhi. 
Dyer, G. (2011). China: Beijing puts its huge piles of cash to work. FT.com Retrieved Apr 27, 2011, from http://www.ft.com/cms/s/0/0d768fea-273f11e0-80d7-00144feab49a.html\#ixzz1QR0DotUs

Economist, The (2010). Industrial production. The Economist, Retrieved Jan 22, 2011, from http://www.economist.com/node/17043603?story_id=17043603

Economy, E. (2001). The Impact of International Regimes on Chinese ForeignPolicy Making: Broadening Perspectives and Policies...But Only to a Point. In D. Lampton (Ed.), The Making of Chinese Foreign and Security Policy in the Era of Reform, 1978-2000. (pp. 230-253). Stanford, CA: Stanford University Press.

Fan, G., Stern, N., Edenhofer, O., Xu, S., Eklund, K., Ackerman, F., Hallding, K. (2011). The economics of climate change in China: towards a low carbon economy. Washington, DC: Earthscan.

Finamore, B. (2011, March 5). China Puts Forth Energy Intensity, Carbon Intensity and Total Energy Consumption Targets in Twelfth Five Year Plan in Effort to Tackle "Unsustainable Economic Growth". Retrieved from http://switchboard. nrdc.org/blogs/bfinamore/china_puts_forth_energy_intens.html

Geldart, C., \& Lyon, P. (1981). THE GROUP OF 77 - A PERSPECTIVE VIEW. [Article]. International Affairs, 57(1), 79-101.

Godement, F., Duchâtel, M., \& Moncharmont, O. (2010). Geopolitics on Chinese Terms. China Analysis Retrieved April 23, 2011, from http://www.centreasia.eu/ sites/default/files/publications_pdf/china_analysis_geopolitics_on_chinese_ terms_september2010.pdf

Goswami, U. A. (2010). Cancun Strategy: BASIC meet in China today for international consultation \& analysis, The Economic Times. Retrieved from http://articles.economictimes.indiatimes.com/2010-10-11/news/ 27577305_1_international-consultation-g-77-basic-meeting

Government of Brazil. (2010). Brazil's Second National Communication to the United Nations Framework Convention on Climate Change [online]. Retrieved from http://www.mct.gov.br/index.php/content/view/326751.html/.

Government of India. (2010). Submission to Yvo de Boer, Executive Secretary, UNFCCC, 30 January 2010. Retrieved from http://unfccc.int/files/meetings/ application/pdf/indiacphaccord_app2.pdf

Government of the Republic of South Africa. (2010). National Climate Change Response Green Paper Retrieved Jun 29, 2011, from http://www. climateresponse.co.za/home/gp/toc

Habib, A. (2011, 19 Apr). South Africa's Foreign Policy Under Zuma. The Broker Retrieved May 20, 2011, from http://www.thebrokeronline.eu/Blogs/Emergedpowers-in-the-21st-century/South-Africa-s-foreign-policy-under-Zuma/\% 28language $\% 29 /$ eng-GB

Hall, P. (1993). Policy Paradigms, Social Learning and the State: The Case of Economic Policymaking in Britain. Comparative Politics, 25, 275-297.

Hallding, K., Han, G., \& Olsson, M. (2009a). A Balancing Act: China's Role in Climate Change. In Prime Ministers Office (Ed.), Sustainable Development Commission. Stockholm: Government Offices of Sweden. 
Hallding, K., Han, G., \& Olsson, M. (2009b). China's Climate- and Energy-security Dilemma: Shaping a New Path of Economic Growth. [Climate change; Sustainable development; Economic growth; Climate protection]. Journal of Current Chinese Affairs, 38(3), 119-134.

Hance, J. (2008). Poll: Chinese more concerned about the environment than Americans Retrieved 280411, 2011, from http://news.mongabay.com/ 2008/0407-hance_china_poll.html

Harding, H., \& Shambaugh, D. L. (1987). Patterns of cooperation in the foreign relations of modern China. Paper presented at the China's Cooperative Relationships: partnerships and alignment in modern Chinese foreign policy., Wintergreen, VA.

Hochstetler, K., \& Viola, E. (2011). Brazil and the Multiscalar Politics of Climate Change. Paper presented at the 2011 Colorado Conference on Earth Systems Governance, Colorado State University, Fort Collins, Colorado. http://cc2011.earthsystemgovernance.org/abstracts.html

Hooghe, L., \& Marks, G. (2001). Types of Multi-Level Governance. 5(11). Retrieved from http://eiop.or.at/eiop/texte/2001-011a.htm

Ikenberry, G. J. (2008). The Rise of China and the Future of the West. Foreign Affairs, 87(1), 15.

International Energy Agency (IEA). (2009). World Energy Outlook 2009: International Energy Agency.

International Energy Agency (IEA). (2010). CO2 emissions from fuel combustion: Highlights IEA Statistics (2010 Edition ed.): International Energy Agency.

Jha., P. S. (2009). Indian Public Perceptions of the International Climate Change Negotiations. In David Michel \& Amit Pandya (Eds.), Indian Climate Policy: Choices and Challenges (pp. 31-36). Washington DC: Henry L. Stimson Centre.

Joint Statement Issued at the Conclusion of the Fourth Meeting of Ministers of BASIC Group. (2010, 27 Jul) Retrieved 29 April, 2011, from http://www.brasil. gov.br/news/para/press/press-releases/july/jointstatement-issued-at-theconclusion-of-the-fourth-meeting-of-ministers-of-the-basicgroup/br_model1? set_language $=\mathrm{en}$

Joint Statement Issued at the Conclusion of the Second Meeting of Ministers of BASIC Group. (2010, 24 Jan) Retrieved 29 April, 2011, from http://www. chinaembassy.org.in/eng/sgxw/t653628.htm

Joint Statement issued at the conclusion of the Third Meeting of BASIC Ministers. (2010) Retrieved Sep 5, 2010, from http://moef.nic.in/downloads/publicinformation/BASIC-statement.pdf

Joint Statement Issues at the Conclusion of the Fifth Meeting of Ministers of BASIC group. (2010, 11 Oct) Retrieved 29 April, 2011, from http://moef.nic.in/ downloads/public-information/Fifth-BASIC-Ministerial-Meeting-on-ClimateChange.pdf

Jopson, B. (2010, Aug 5). South Africa to China: let's make it about more than minerals. Retrieved from http://blogs.ft.com/beyond-brics/2010/08/ 24/88906/\#ixzz1QfvQDIMV 
Kartha, S., \& Erickson, P. (2011). Comparison of Annex 1 and non-Annex 1 pledges under the Cancun Agreements. Boston: Stockholm Environment Institute.

Kaufman, A. A. (2010). The "Century of Humiliation," Then and Now: Chinese Perceptions of the International Order. [Article]. Pacific Focus, 25(1), 1-33. doi: 10.1111/j.1976-5118.2010.01039.x

Kim, S. S. (1992). Chinese Foreign Policy in Theory and Practice. In S. S. Kim (Ed.), China and the World: Chinese Foreign Policy Faces the New Millennium (pp. 3-33). Boulder, CO: Westview Press.

Knoke, D., Pappi, F. U., Broadbent, J., \& Tsujinake, Y. (1996). Comparing Policy Networks: Labor politics in the U.S., Germany, and Japan. Cambridge: Cambridge University Press.

Kobayashi, Y. (2003). Navigating Between "Luxury" and "Survival" Emissions: tensions in China's multilateral and bilateral climate change diplomacy. In P. G. Harris (Ed.), Global Warming and East Asia: The Domestic and International Politics of Climate Change. (pp. 86-108). London: Routledge.

Korpoo, Anna, Linda Jakobsson, Johannes Urpelainen, Antto Vihma, \& Alex Luta. (2009). Towards a New Climate Regime: Views of China, India, Japan, Russia and the United States on the Road to Copenhagen. Finnish Institute of International Affairs, FIIA Report (Vol. 19/2009).

Landsberg, C. (2010). Pax South Africana and the Responsibility to Protect. Global Responsibility to Protect, 2(4), 436-457. doi: 10.1163/187598410X51957.

Leahy, J. (2011a, Jan 30). Brazil and China trade tensions set to rise. FT.com Retrieved May 2, 2011, from http://www.ft.com/cms/s/0/5efdeffc-2c99-11e083bd-00144feab49a.html\#ixzz1MF2Z3Fve

Leahy, J. (2011b, Jan 30). Brazilian factories tested by Chinese imports. FT.com Retrieved May 9, 2011, from http://www.ft.com/intl/cms/s/0/447cd722-2c9611e0-83bd-00144feab49a.html\#axzz1QfpHxYii

Leahy, J. (2011c, Apr 27). US and Brazil, getting closer. Retrieved from http://blogs.ft.com/beyond-brics/2011/03/19/us-and-brazil-getting-closer/

Leahy, J. (2011d, Feb 7). US seeks Brazil's support on renminbi. FT.com Retrieved May 2, 2011, from http://www.ft.com/cms/s/0/f3e63012-32ec-11e0-9a6100144feabdc0.html\#ixzz1Rrw7uLMJ

Lin, B.-q., \& Liu, J.-h. (2009). Estimating coal production peak and trends of coal imports in China. Energy Policy, 38(1), 8. doi: 10.1016/j.enpol.2009.09.042.

Lin, E., Xu, Y., Ju, H., \& Ma, S. (2007). China's National Assessment Report on Climate Change (II): Climate change impacts and adaptation. Advance in Climate Change Research(3), 6-11.

Lynas, M. (2009). How do I know China wrecked the Copenhagen deal? I was in the room. guardian.co.uk Retrieved April 23, 2011, from http://www.guardian. co.uk/environment/2009/dec/22/copenhagen-climate-change-mark-lynas

Major Economies Forum (MEF). (2009). Copy of Leaders' declaration from the Major Economies Forum on Energy and Climate, held at L'Aquila, Italy, July 2009. Retrieved 2 August, 2010, from http://www.whitehouse.gov/the_press_office/ Declaration-of-the-Leaders-the-Major-Economies-Forum-on-Energy-andClimate/ 
Mantzikos, I. (2010). The good multilateralists: Brazil and South Africa in the new area of multilateralism. Meridiano 47, 11(118), 6-14.

Margulis, S., \& Dubeux, C. B. S. (Eds.). (2010). Economia da Mudança do Clima no Brasil: Custos e Oportunidades. São Paulo: IBEP Gráfica.

Mark Williams. (1991). Third World Cooperation: The Group of 77 in UNCTAD. London: Pinter.

Marks, D. (2010). China's Climate Change Policy Process: improved but still weak and fragmented. Journal of Contemporary China, 19(67), 16. doi:

$10.1080 / 10670564.2010 .508596$.

Mattlin, M., \& Nojonen, M. (2011). Conditionality in Chinese bilateral lending. Bank of Finnland Discussion Paper 14/2011. Retrieved May 23, 2011, from http:// www.suomenpankki.fi/bofit/tutkimus/tutkimusjulkaisut/dp/Pages/dp1411.aspx

McCurry, J., \& Kollewe, J. (2011, 15 Feb). China overtakes Japan as world's second largest economy, The Guardian, p. 26. Retrieved from http://www.guardian. co.uk/business/2011/feb/14/china-second-largest-economy

McKinsey \& Company. (2009). China's Green Revolution: Prioritizing Technologies to Achieve Energy and Environmental Sustainability. Beijing: McKinsey \& Company.

McKinsey \& Company. (2010). Pathways to a low-carbon economy for Brazil. São Paulo: McKinsey \& Company.

Meng, S. (2010). China will be transparent. chinadialogue Retrieved Mar 22, 2011, from http://www.chinadialogue.net/article/show/single/en/3966

Miller, M. (1995). The Third World in Global Environmental Politics. Buckingham: Open University Press.

Milliband, E. (2009, 21 Dec). The road from Copenhagen, Commentary, The Guardian. Retrieved from http://www.guardian.co.uk/commentisfree/2009/ $\mathrm{dec} / 20 /$ copenhagen-climate-change-accord

Ministério da Ciência e Tecnologia. (2010, Nov). Second National Communication of Brazil to the United Nations Framework Convention on Climate Change. Climate Change Retrieved Jan 10, 2011, from http://www.mct.gov.br/index.php/ content/view/326984.html

Ministério de Minas e Energia (MME). (2010). Resenha Energética Brasileira: Exercício de 2009 Retrieved 7 AUG, 2010, from http://www.joinville.ifsc.edu.br/ roberto.sales/EFE/Aulas\%202011.1/Aula\%20-\%20BEN\%20-\%202009/ Resenha_Energetica_2009_-_PRELIMINAR.pdf

Narlikar, A. (2010a). New powers : how to become one and how to manage them. London: Hurst.

Narlikar, A. (2010b). New powers in the club: the challenges of global trade governance. International Affairs, 86(3), 12.

Noronha, L. (2009). Climate Change and India's Energy Policy: Challenges and Choices. In D. Michel \& A. Pandya (Eds.), Indian Climate Policy: Choices and Challenges (pp. 7-11). Washington: Henry L. Stimson Centre.

OECD. (2007). Environmental Performance Reviews: China. Paris: OECD. 
Parks, B. C., \& Roberts , J. T. (2008). Inequality and the Global Climate Regime: Breaking the North-South Impasse. Cambridge Review of International Affairs, 21(4), 621-648.

Pearson, S. (2011, Mar 6). Brazil's carnival is "made in China". FT.com Retrieved May 4, 2011, from http://www.ft.com/cms/s/0/c5985786-468c-11e0-967a00144feab49a.html\#axzz1MEvqfUpe

Purvis, N., \& Stevenson, A. (2010). Rethinking Climate Diplomacy: New ideas for transatlantic cooperation post-Copenhagen. Washington, DC: The German Marshall Fund of the United States.

Rajan, M. K. (1997). Global Environmental Politics: India and the North-South Politics of Global Environmental Issues. Dehli: Oxford University Press.

Ramo, J. C. (2004). The Beijing consensus. London: Foreign Policy Centre.

Rapp, T., Schwägerl, C., \& Traufetter, G. (2010). How China and India Sabotaged the UN Climate Summit. Spiegel Online International Retrieved April 22, 2011.

Roberts, C. (2010). Russia's BRICs Diplomacy: Rising Outsider with Dreams of an Insider. Polity, 42(1), 38-73. doi: 10.1057/pol.2009.18

Rubin, J. (2011, May 1). Is Peak Coal Comming? Retrieved from http://www. jeffrubinssmallerworld.com/2011/04/27/is-peak-coal-coming/

Sabatier, P. A., \& Jenkins-Smith, H. (Eds.). (1993). Policy Change and Learning: An Advocacy Coalition Approach. Boulder, CO: Westview Press.

Sabinet Cape Town Office. (2009, Nov 6). South Africa's Developmental Challenges Outweigh Carbon Reduction Targets. SabinetLaw Retrieved 1 May, 2011, from http://www.sabinetlaw.co.za/environmental-affairs-and-water/articles/southafricas-developmental-challenges-outweigh-carbon-redu

Secretariat for Social Communication - International Area. (2011). Brazil-China Retrieved May 10, 2011, from http://www.brasil.gov.br/para/press/files/factsheet-brazil-china-trade

Senona, J. (2010). BRIC and IBSA Forums: Neo-liberals in Disguise or Champions of the South? Policy Briefing: South African Institute of International Affairs.

Sethi, N. (2009, Oct 19). Jairam for major shift at climate talks. The Times of India Retrieved Jul 7, 2011, from http://articles.timesofindia.indiatimes.com/ 2009-10-19/india/28079441_1_greenhouse-gas-emission-reduction-climatenegotiations-change-negotiations

Sethi, N. (2010). SA toes West line, ruptures BASIC unity, Time Times of India. Retrieved from http://articles.timesofindia.indiatimes.com/2010-1009/india/28235935_1_bali-action-plan-basic-meeting-basic-group

Siddiqi, T. (2011). CHINA AND INDIA: MORE COOPERATION THAN COMPETITION IN ENERGY AND CLIMATE CHANGE. [Article]. Journal of International Affairs, 64(2), 73-90.

Stern, T., \& Antholis, W. (2007). A changing climate: The road ahead for the United States. [Article]. Washington Quarterly, 31(1), 175-188.

Stockholm Environment Institute, \& United Nations Development Programme (China). (2002). Making green development a choice : China Human Development report 2002. Oxford: Oxford University Press. 
TERI. (2008). Mitigation Options for India: the Role of the International Community. New Delhi: The Energy and Resources Institute.

Trade Profiles. (2010). Available from World Trade Organisation Statistics Database Retrieved Nov 1, 2010, from World Trade Organisation http:// stat.wto.org/Home/WSDBHome.aspx

Trennepohl, N. (2010). Brazil's Policy on Climate Change: Recent Legislation and Challenges to Implementation. Carbon and Climate Law Review, 2010(3), 271-277.

TWN Third World Network. (2011). TWN Cancun News Updates and Climate Briefings (November/December 2010). Penang: TWN.

Udit Mathur, \& George C. Varughese. (2009). From "Obstructionist" to Leading Player: Transforming India's International Image. In David Michel \& Amit Pandya (Eds.), Indian Climate Policy: Choices and Challenges (pp. 43-48). Washington: Henry L. Stimson Centre.

. United Nations Framework Convention on Climate Change. (1992) Full text of the convention. Retrieved March 11, 2011, from http://unfccc.int

Unmüßig, B., \& Cramer, S. (2008). Climate Change in Africa. GIGA Focus No 2. Retrieved 30 Jun, 2011, from http://www.boell.de/downloads/worldwide/ giga2_hamburg_afrika.pdf

Van den Bosch, S. (2011, 31 Jan). African LDCs Won't Benefit Much from BRICS Arrival. IPSNews online, from http://ipsnews.net/news.asp?idnews=54296

Vidal, J. (2009). Copenhagen climate summit in disarray after "Danish text" leak. guardian.co.uk Retrieved April 22, 2011, from http://www.guardian.co.uk/ environment/2009/dec/08/copenhagen-climate-summit-disarray-danish-text

Vihma, A. (2010). The Elephant in the Room: The new G77 and China dynamics in climate talks. Briefing Paper, (62). Retrieved from www.fiia.fi/assets/ publications/UPI_Briefing_Paper_62_2010.pdf

Vihma, A. (2011a). India and the Global Climate Governance: Between Principles and Pragmatism. Journal of Environment \& Development, 20(1), 26p. doi: $10.1177 / 1070496510394325$.

Vihma, A. (2011b). Negotiating Solidarity: The G77 through the prism of global climate change negotiations (Report for Nordic Ad Hoc Group on Global Climate Change Negotaitions (NOAK) ed.): Finnish Institute of International Affairs (FIIA).

Vihma, A., Mulugetta, Y., \& Karlsson-Vinkhuuyzen, S. I. (2011). Negotiating Solidarity? The G77 through the prism of climate change. Global Change, Peace \& Security, 23(3).

Webb, T. (2010). Petrobras aspires to be world's biggest oil producer, Guardian.

White, L. (2009). IBSA Six Years On: Co-operation in a New Global Order Policy Briefing (pp. 4): South African Institute of International Affairs.

Williams, M. (2005). The Third World and Global Environmental Negotiations: Interests, Institutions and Ideas. Global Environmental Politics, 5, 48-69.

Wolf, M. (2011, May 23). Manufacturing at risk from global shift to Asia, Financial Times (Special Report). Retrieved from http://www.ft.com/intl/cms/434f23d8828a-11e0-8c49-00144feabdc0.pdf 
World Development Indicators \& Global Development Finance. (2010). Available from The World Bank World dataBank Retrieved Oct 28, 2010, from The World Bank http://databank.worldbank.org/ddp/home.do

World Resources Institute (WRI). (2009). Summary of UNFCCC Submissions, August 2008-October 29, 2009 World Resources Institute Working Paper. Washington DC: World Resources Institute.

World Wind Energy Association WWEA. (2011). World Wind Energy Report 2010 Retrieved May 30, 2011, from http://www.wwindea.org/home/images/ stories/pdfs/worldwindenergyreport2010_s.pdf

Wübbeke, J. (2010). The Power of Advice: Experts in Chinese Climate Change Politics. Lysaker: Fritiof Nansen Institute.

WWF. (2011). Clean Economy, Living Planet - Ready for growth: Summary of Cleantech Country Index. Paper presented at the Cleantech Forum May 9, Amsterdam.

Xinhua. (2011). BRIC trade helps stabilize economies during crisis. Xinhua net Retrieved May 22, 2011, from http://news.xinhuanet.com/english2010/china/ 2010-04/15/c_13252530.htm

Zhao, C., Tian, T., \& Wei, D. (2009). Verdant mountains cannot stop water flowing; eastward and the river keeps on going, Xinhua News Agency. Retrieved from http://www.fmprc.gov.cn/eng/zxxx/t648096.htm

Zhu, L. (2008). The Domestic Sources of China's Foreign Policy and Diplomacy. In P. Kerr, S. Harris \& Q. Yaqing (Eds.), China's "New" diplomacy: Tactical or fundamental change? (pp. 109-130). New York, NY: Palgrave Macmillan. 


\section{กorden}

\section{Nordic Council of Ministers}

Ved Stranden 18

DK-1061 Copenhagen K

www.norden.org

\section{Together Alone}

BASIC countries and the climate change conundrum

Since 2009, Brazil, South Africa, India and China - known as the BASIC group of countries - have cooperated in international climate negotiations, reflecting their aspiration to have a larger say in global politics. But there are some who claim that the approach of the bloc has obstructed progress in the talks.

Yet this is a superficial view: for real insight into the BASIC group's approach, it is necessary to grasp the development concerns of each country and the geopolitical value they see in cooperation. As four separate states, it is domestic policy priorities that condition how far they can work together, and what they can contribute to climate discussions.

This report from the Stockholm Environment Institute arrives at a more nuanced understanding of the BASIC cooperation. Such an understanding is crucial if international climate negotiations are to succeed.

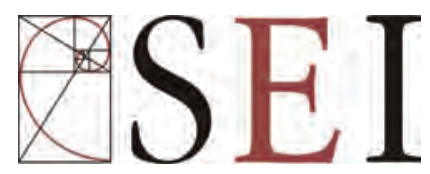

